\title{
Genetic aspects of
}

piglet survival 
Promotor:

Prof. dr. ir. J. A. M. van Arendonk

Persoonlijk hoogleraar bij Departement Dierwetenschappen Wageningen Universiteit

Co-promotor:

Dr. ir. T. van der Lende

Universitair docent bij Departement Dierwetenschappen

Wageningen Universiteit

Samenstelling promotiecommissie:

Prof. Dr. agr. Dr. h.c. mult. E. Kalm

(Christian-Albrechts-Universität, Kiel)

Prof. dr. ir. M.W.A. Verstegen

(Wageningen Universiteit)

Prof. dr. M.A.M. Taverne

(Rijksuniversiteit Utrecht)

Dr. ir. P.W. Knap

(Pig Improvement Company, Kiel) 


$$
\text { NNO8201, 2994 }
$$

\title{
Genetic aspects of \\ piglet survival
}

Egbert Frank Knol

\begin{abstract}
Proefschrift
ter verkrijging van de graad van doctor op gezag van de rector magnificus van de Wageningen Universiteit,

Prof. dr. ir. L. Speelman,

in het openbaar te verdedigen

op dinsdag 12 juni 2001

des namiddags te half twee in de Aula.
\end{abstract}

0.16 .8265 
Foto omslag: TOPIGS

Knol, E.F. Genetic aspects of piglet survival. Doctoral thesis, IPG, Institute for Pig Genetics B.V. P.O. Box 43 and Animal Breeding and Genetics Group, Wageningen University, P.O. Box 338, 6700 AH Wageningen, The Netherlands.

Het in dit proefschrift beschreven onderzoek is financieel gesteund door de Technologiestichting STW en begeleid door het Gebied Aard- en Levenswetenschappen (ALW).

ISBN 90-5808-418-3

Printed by Universal Press, Veenendaal, The Netherlands

\begin{abstract}
This dissertation studies the genetic variation in piglet survival. Piglet survival was defined as survival from pre-farrowing to weaning. Data sets used involved individual piglet information of around 33.000 litters. Genotypes of the piglet, of the biological mother and of the sow nursing the piglet were important for piglet survival. Estimated heritabilities were low, but genetic variation was considerable. Selection on the direct effect of piglet survival will result in measurable differences in survival. Relevant genetic correlations of piglet survival were found for litter size, within litter variation in birth weight, and in feed intake and ultrasonic measured backfat during the finishing phase. Genetic correlations with birth weight and correlated responses of selection on piglet survival on birth weight were effectively zero or even slightly negative. Consequences of the inclusion of selection for increased piglet survival in the breeding goal were discussed. For reproduction traits this inclusion will yield a more balanced progress. For finishing traits it will lower the genetic trend in percentage lean in the carcass.
\end{abstract}


1008201,2994

\section{Stellingen}

1. Door selectie kan de sterfte van biggen tot aan spenen, inclusief doodgeboorte, merkbaar worden verlaagd.

Dit proefschrift.

2. Zowel de genen van de big, de genen van de biologische moeder als de genen van de zeug die de big grootbrengt, zijn van belang voor de overlevingskansen van biggen.

Dit proefschrift.

3. De lagere overlevingskans van nakomelingen van stress-positieve Pietrain beren is niet het gevolg van stressgevoeligheid maar van krappe vet reserves.

4. Selectie op verhoging van de immuun-respons tegen ziektekiemen zal de overlevingskans van biggen niet noemenswaard verhogen.

5. Residual feed intake adds no new genetic information.

Kennedy, van der Werf and Meuwissen (1993) J. Anim. Sci 71: 3239-3250.

6. Biggen zonder $\mathrm{Y}$-chromosoom met een verzorgende zonder $\mathrm{Y}$-chromosoom overleven beter dan wanneer er wel Y-chromosomen in het spel zijn.

7. In het belang van mens en dier moet de dierlijke productie (weer) regionaal worden.

8. Het geboorteproces is voor biggen slechts een horde op de weg naar het slachthuis.

Stellingen bij het proefschrift van Egbert F. Knol

'Genetic aspects of piglet survival'

Wageningen Universiteit, 12 juni 2001 


\section{Contents}

Chapter 1 Introduction 1

Chapter 2 Genetic parameters of litter mortality in pigs 7

Chapter 3 Direct, maternal and nurse sow effects on farrowing-, pre-weaning and total piglet survival

Chapter 4 Predictive value of breeding values in three strategies to select for improved piglet survival

Chapter 5 Genetic correlations between piglet survival, birth weight and performance traits

Chapter 6 Discussion

Chapter 7 Samenvatting

Chapter 8 Summary

Curriculum vitae 
Piglet losses were classified as:

(a) necrotic or mummified piglets;

(b) stillborns - includes all piglets that were dead at birth and born in the embryonic membranes;

McKay (1993) 


\section{Introduction}

Pig farmers all over the world work hard to produce good quality lean meat as efficient as possible. Breeding companies or herdbook associations, where economically important traits are improved through selection, support these efforts. An important factor in the efficiency of pork production is the efficiency of piglet production, most of the time captured in the trait weaned piglets per sow per year. Roughly this trait can be broken down in the traits returning into heat after weaning (IWO), litter size and piglet survival. A more or less definitive description of the genetic aspects of IWO has been given by ten Napel (1996) and similarly the review of the genetic aspects of litter size by Haley et al. (1988) can be seen as a landmark in the discussion on the possibility of selection on litter size.

Genetic aspects of piglet survival have been studied in many situations, but consensus on the possibility of selection for increased survival is lacking. Lamberson and Johnson (1984) did not expect selection for increased survival to be successful. Blasco et al. (1995) summarized genetic parameters and concluded that more research and better data sets were needed to address the genetics of piglet survival more precisely. Kerr and Cameron (1995) and more recently Roehe and Kalm (2000) concluded that piglet survival has a heritable component, but that this heritability is too low to expect genetic progress and both suggested selection for increased birth weight as an alternative.

Current piglet mortality is around $19 \%$ with large herd to herd variation (see e.g. Friendship et al., 1986). In the USA in 1998 total number born was 11.0 piglets with a total mortality (stillbirths and pre-weaning deaths) of 19.4\% (1998 PigCHAMP database). In the Netherlands in 1999 these figures were 12.2 total born and $19.3 \%$ total mortality (Bedrijfsvergelijking SIVA software BV). For the period between 1984 and 1999 an average of $18 \%$ piglet mortality was reported by Grandinson et al. (2000) for a research farm in Denmark. Even higher mortality rates can be found in literature. In a Canadian selection experiment where data was collected from 1983 to 1992 the preweaning mortality was $24 \%$ (McKay, 1993). 
The importance of farm management on piglet survival is widely acknowledged (e.g. Bereskin et al., 1973; Holyoake et al., 1995; White et al., 1996; Marchant et al., 2000). Barn climate, crate structure and especially the presence of dedicated people have an important influence on pre-weaning mortality and to a lesser extend on number stillborn piglets. In Brazil 24-hr farrowing surveillance is not uncommon. This can reduce preweaning mortality to levels as low as $4 \%$. It reflects what can be achieved under ideal management conditions.

Piglet survival involves potentially three different genotypes, the genotype of the sow, the genotype of the sow nursing the piglet and the genotype of the piglet itself. Piglet survival can be defined in terms of vitality of the piglet and mothering ability of the sow nursing the piglet. Vitality of the piglet is, in this thesis, defined as the potential of the piglet to survive until weaning. Mothering ability is defined as the potential of a sow to raise the live born piglets entrusted to her; this includes the cross-fostered piglets. Crossfostering is an important factor in the analyses, since cross-fostering is non-random. Assumed weaker piglets are transferred to sows with an assumed good mothering ability.

Another approach is the analysis of litter mortality, or litter survival, where piglet survival is defined as a litter trait. It is the ability of a sow to farrow piglets that will survive until weaning. In genetic terms litter survival is similar to the maternal effect of piglet survival, if piglet survival is analyzed as a trait of the piglet.

Table I: Trends and correlated trends after 14 generations of selection to increase litter size (Johnson et al., 1999)

\begin{tabular}{ll}
\hline Trait, \# per litter & $\begin{array}{l}\text { Trend } \\
\text { Generation }\end{array}$ \\
\hline Total born & $0.212^{* * a}$ \\
Number of stillborn pigs & $0.115^{*}$ \\
Number born alive & $0.103 * *$ \\
Number weaned & $-0.046^{* *}$ \\
\hline$* \mathrm{P}<0.05 ; * * \mathrm{P}<0.01$ &
\end{tabular}


The genetic trends of herdbook breeds or commercial lines are clearly positive for litter size and gain, and negative for backfat. In general these trends do not seem to favor piglet survival. In a single trait litter size selection experiment, Johnson et al. (1999) found a significantly positive trend in total number of piglets born per litter, evenly divided over stillborn and live born piglets (Table 1). There is a negative trend in weaned piglets per litter, indicating an increased pre-weaning mortality. This was a welldocumented successful multi generation selection experiment to increase litter size with a negative correlated response in terms of piglet survival.

Similarly negative correlated responses were found for piglet survival after lean gain selection. McKay (1993) reported a difference in backfat of $-0.6 \mathrm{~mm}$ per generation between a Yorkshire lean gain selection and control line. Correlated response in preweaning survival was $-0.9 \%$ per generation (Figure 1 ). In a similar Hampshire selection experiment a lower trend in backfat was realized and no correlated trend in survival percentage was seen. Both selection experiments resulted in higher numbers of deaths, according to the author mainly due to the sow.
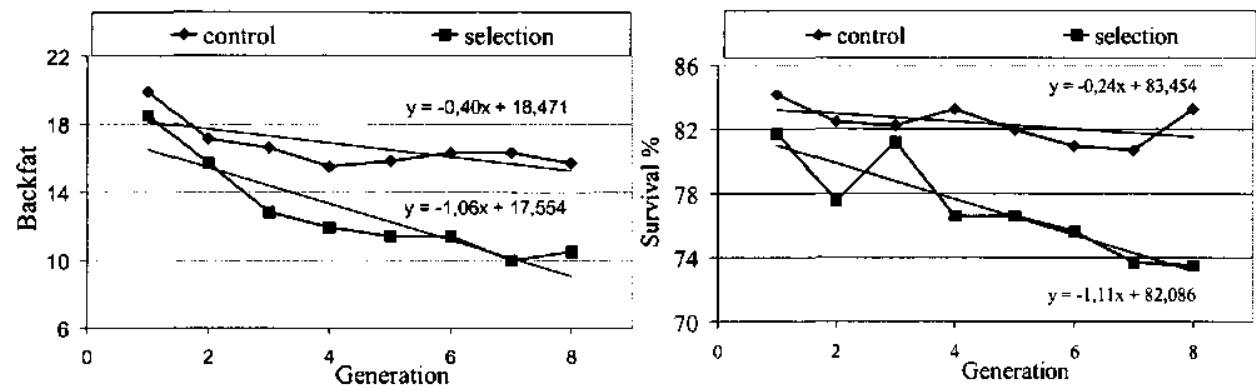

Figure 1: Generation averages for backfat and pre-weaning survival in a control and a selection line for increased lean gain (adapted from McKay, 1993).

Herpin et al. (1993) postulated a lower maturity for piglets after selection for increased lean gain. Tuchsherer et al. (2000) investigated traits of newborn piglets with respect to survival. They summon breeding programs to ' ...ensure a high physiological maturity ... of neonates.' 
Piglet mortality is high, sometimes very high. The direction of correlated responses after selection for increased efficiency point to a further increase in mortality. Through investment in management measures mortality can be kept somewhat under control. However, if there are negative correlated responses of current selection, the process of management improvement needs to be continuous. Piglet survival has a genetic component and selection on increased piglet survival could increase piglet survival and/or reduce costs of management measures and/or circumvent the negative correlated genetic responses of selection for increased litter size and increased lean gain.

The aim of this thesis is, therefore 1) to estimate the genetic variance contributions of the different animal components which influence piglet survival, 2) to investigate the expected response of selection for increased piglet survival, 3) to investigate the relations between piglet survival and litter traits and between piglet survival and finishing traits to evaluate consequences of alternative selection strategies.

\section{Literature cited}

Bedrijfsvergelijking SIVA software BV., 1999. Kengetallenspiegel. Available at: http://www.siva.nl/nl/result/rzlan99.htm. Accessed at: July 3, 2000.

Bereskin, B., C.E. Shelby, and D.F. Cox. 1973. Some factors affecting pig survival. J. Anim. Sci. 36: 821-827.

Blasco, A., J. P. Bidanel, and C. S. Haley. 1995. Genetics and Neonatal Survival. In: M.A. Varley (ed.) The Neonatal Pig. Development and Survival. pp 17-38. CAB International, Wallington, Oxon, UK.

Friendship, R.M., M.R. Wilson, and I. McMillan. 1986. Management and housing factors assciated with piglet preweaning mortality. Can. Vet. J. 27: 307-311.

Grandinson, K., L. Rydhmer, E. Strandberg and, M.S. Lund. 2000. Estimation of genetic parameters for mortality and causes of death in piglets. EAAP 2000, The Hague.

Haley, H.C., E. Avalos, and C. Smith. 1988. Selection for litter size in the pig. Anim. Breed. Abstr. 56: 317-332.

Holyoake P.K., G.D. Dial, T. Trigg, and V.L. King. 1995. Reducing pig mortality through supervision during the perinatal period. J. Anim. Sci. 73: 3543-3551. 
Johnson, R.K., M.K. Nielsen, and D. S. Casey. 1999. Responses in ovulation rate, embryonal survival, and litter traits to 14 generations of selection to increase litter size. J. Anim. Sci. 77: 541-557.

Kerr, J.C., and N.D. Cameron. 1995. Reproductive performance of pigs selected for components of efficient lean growth. Anim. Sci. 60: 281-290.

Lamberson, W.R. and R.K. Johnson. 1984. Preweaning survival in swine: Heritability of direct and maternal effects. J. Anim. Sci. 59: 346-349.

Marchant J.N., A.R. Rudd, M.T. Mendl, D.M. Broom, M.J. Meredith, S. Corning, and P.H. Simmins. 2000. Timing and causes of piglet mortality in alternative and conventional farrowing systems. Vet. Rec. 147: 209-214.

McKay, R.M. 1993. Preweaning losses of piglets as a result of index selection for reduced backfat thickness and increased growth rate. Can. J. Anim. Sci. 73: 437-442.

PigCHAMP database, 1998. Swine data management's Pigchamp record service. Available at: http:/www.netins.net/showcase/swinedata. Accessed July 3, 2000.

Roehe, R., and E. Kalm. 2000. Estimation of genetic and environmental risk factors associated with pre-weaning mortality in piglets using generalized linear mixed models. Anim. Sci. 70: 227-240.

Ten Napel, J. 1996. Genetic aspects of intervals from weaning to oestrus. Dissertation, Department of Animal Breeding, Wageningen, Agricultural University.

Tuchsherer, M., B. Puppe, A. Tuchscherer, and U. Tiemann. 2000. Early identification of neonates at risk: traits of newborn piglets with respect to survival. Theriogenology. 54: 371-388.

White K.R., D.M. Anderson, and L.A. Bate. 1996. Increasing piglet survival through an improved farrowing management protocol. Can. J. Anim. Sci. 76: 491-495. 
Piglet losses were classified as:

(h) total deaths due to the sow - the sum of the piglets killed directly by the sow, piglets that died or were euthanized because of injuries inflicted by the sow, and piglets that starved to death beause of insufficient milk production by the sow;

(i) deaths due to scours - piglets that died by contracting E. coli scours;

McKay (1993) 


\title{
Genetic parameters of litter mortality in pigs
}

\begin{abstract}
Data collected in a commercial breeding program were used to estimate genetic parameters for different definitions of piglet mortality. Individual birth weights, mortality details, and cross-fostering information were available on all piglets from 16,704 litters. Sows of one sire, two dam lines and crosses between the two dam lines were involved. All mortality traits were related to the total number of piglets born in each litter. Traits analyzed were \#stillborn, \#pre-weaning deaths, \#total deaths up to weaning, \%stillborn, \%pre-weaning mortality, and \%litter mortality (that is \#total deaths/ \#total born). Univariate estimates of heritability for these traits were 0.04,0.08,0.07,0.05, 0.06, and 0.06 , respectively (s.e. between 0.009 and 0.011 ). Heritabilities of these mortality traits remained very similar after linear and quadratic corrections for each of the traits, total number born, average birth weight, variation in birth weight, and gestation length. $\%$ Stillbirth had a positive genetic correlation with \%pre-weaning mortality of $0.14 \pm$ 0.13. The genetic correlations between mortality traits and variation in birth weight were moderately positive and higher than the phenotypic correlations. Genetic variation in $\%$ litter mortality was high $\left(\sigma_{g}^{2}\right.$ was 16.5 before and 15.4 after correction $-C V_{g}$ of $\left.\sim 0.25\right)$. These findings are promising for genetic selection against piglet mortality.
\end{abstract}

Key Words: Pigs, Piglet mortality, Genetic Parameters, Stillborn, Birth Weight

\section{Introduction}

Peri- and postnatal mortality in pigs results in substantial financial losses. In addition, there is an emotional impact of mortality on farmers and consumers. In the USA in 1998 total number born was 11.0 piglets with a total mortality from stillbirths and pre-weaning

\section{Submitted:}

Knol, E.F. Genetic parameters of litter mortality in pigs 
deaths of $19.4 \%$ (1998 PigCHAMP database). In the Netherlands in 1999 these figures were 12.2 total born and $19.3 \%$ total mortality, respectively (Bedrijfsvergelijking SIVA software BV.). Increased knowledge and better farm management may result in reduced piglet mortality. However, the trend towards larger farms tends to lead to reduced time spent per individual animal.

Selection pressure on total number born has increased in past years and the genetic correlation between total number born and mortality is clearly positive (Johnson, 1999). Predisposing factors in piglet mortality are birth weight, genetic abnormalities, inbreeding depression, short gestation length leading to immature piglets being born and duration of farrowing (Zaleski et al., 1993). Absolute birth weight and birth weight relative to the litter average could be important for survival (English and Wilkinson, 1982; Lee and Haley, 1995).

Unfortunately, the genetic parameters associated with piglet mortality are poorly described (Blasco et al., 1995). Several authors have addressed the topic of mortality since, and have concluded that heritabilities are too low to achieve successful selection against mortality. Consequently, the advice offered has been to select for increased birth weight in order to profit from the negative correlation between birth weight and mortality (Kerr and Cameron, 1995, Roehe and Kalm, 2000).

The objectives of this study were to analyze:

1) genetic aspects of the number of stillborn, the number of pre-weaning deaths, the sum of these two traits and their respective proportional losses, and

2) the relationship of mortality with four litter traits: total number born, average birth weight, (within litter) variation in birth weight, and gestation length.

Emphasis was placed on the genotype of the dam.

\section{Material and Methods}

\section{Animals}

Data on piglet mortality and related traits originated from the commercial breeding company TOPIGS in their Dalland lines. Farmers collected data from January 1993 until March 1997 on 12 nucleus and multiplier farms located in the Netherlands, Belgium, and France. Data collection procedures were similar on all farms and data were stored and 
validated centrally. Boars used were available from a central AI station and randomly used over farms. All farms accommodated at least two lines or crosses.

A data set of 16,704 litters with full pedigree information was available. The litters originated from two dam lines D1 and D2, their reciprocal crosses D12 and D21 and from one sire line S2. Up to 1989 , all lines were selected as multipurpose lines using selection indexes with minor specialization of the lines. In 1989, an animal model was introduced and specific breeding objectives for the sire and dam lines were implemented.

Total number born (TNB) or litter size equals the sum of the number stillborn plus live born. All piglets, including stillborn but excluding mummified, were weighed at birth in a daily routine, allowing a maximum of $24 \mathrm{~h}$ between birth and recording of the weight. Variation in birth weight (VAR) was calculated within litter and expressed as the standard deviation in $\mathrm{kg}$ per litter. Average birth weight (ABW) included the weight of stillborn piglets, but not of mummified piglets. Gestation length (GEST) was the difference between date of farrowing and date of first insemination in the last estrus. Induction of farrowing was not recorded. On most farms farrowing was induced only if gestation length was well above the average of the line. However, one farm routinely induced approximately $50 \%$ of the sows. A piglet was registered as stillborn, when it was found dead behind the sow at the first check-up after farrowing ( $\leq 12 \mathrm{~h}$ after birth), without external signs of having been alive. A piglet was recorded as a pre-weaning death if it was born alive and died before weaning, which was on average on 28 days after farrowing. The term litter refers to all piglets born from the biological mother, i.e. the genetic littermates. Cross fostering of piglets was registered accurately on an individual piglet basis, as was mortality. However, in the current analysis cross fostering was ignored. Although registration was on an individual piglet basis all analyses were performed on a litter basis.

\section{Mortality Definitions}

All mortality traits of interest were based on the number of stillborn and pre-weaning deaths. The following traits were analyzed:

1. \#stillborn per litter

2. \#pre-weaning deaths per litter

3. \#total deaths per litter (= \#stillborn + \#pre-weaning deaths)

4. \%stillborn (100* \#stillborn / \#total born) 
5. \%pre-weaning mortality ( $100^{*} \#$ pre-weaning deaths / born alive)

6. \%litter mortality (100* \#total dead / \#total born)

Trait $6, \%$ litter mortality, relates to all mortality of fully formed littermates up to weaning. In many data sets this trait is not accurately known, since cross-fostered piglets, in most situations, are not followed on an individual basis.

The data set contained multiple litters per sow and, therefore, allowed estimation of a permanent environment effect. Service sire information was also available, which was used to assess the influence of the sire of the piglets.

\section{Statistical Analysis}

Genetic analyses were performed using the ASREML package of Gilmour et al. (1999). Simple single trait models (model 1 and 1a) were used initially to examine permanent environment and service sire effects. Linear and quadratic corrections for litter traits total born, average birth weight, variation in birth weight, and gestation length were applied in model 2. Bivariate genetic correlations were calculated with the use of model 1a for the litter traits and model 2 for the mortality traits. Analyses were repeated within each pure line to check consistency of the genetic parameters.

$$
\begin{aligned}
\mathrm{Y}= & \mu+\text { Line }_{\mathrm{i}}+\text { HYS }_{\mathrm{j}}+\text { Parity }_{\mathrm{k}}+\text { Boar }_{\mathrm{l}}+\text { Perm }_{\mathrm{m}}+\text { Animal }_{\mathrm{n}}+\text { error }_{\mathrm{ijklmn}} \\
\mathrm{Y}= & \mu+\text { Line }_{\mathrm{i}}+\mathrm{HYS}_{\mathrm{j}}+\text { Parity }_{\mathrm{k}}+\quad+\text { Perm }_{\mathrm{m}}+\text { Animal }_{\mathrm{n}}+\text { error }_{\mathrm{ijkmn}} \\
\mathrm{Y}= & \mu+\text { Line }_{\mathrm{i}}+\mathrm{HYS}_{\mathrm{j}}+\text { Parity }_{\mathrm{k}}+\quad+\text { Perm }_{\mathrm{m}}+\text { Animal }_{\mathrm{n}}+ \\
& \mathrm{b}_{1} * \mathrm{TNB}+\mathrm{b}_{2} * \mathrm{ABW}+\mathrm{b}_{3} * \mathrm{VAR}+\mathrm{b}_{4} * \mathrm{GEST}+\text { error } \\
& \mathrm{b}_{5} * \mathrm{TNB}^{2}+\mathrm{b}_{6} * \mathrm{ABW}^{2}+\mathrm{b}_{7} * \mathrm{VAR}^{2}+\mathrm{b}_{8} * \mathrm{GEST}^{2}+\text { error }_{\mathrm{ijkmn}}
\end{aligned}
$$

Where:

Line $_{i}$ is the line or cross $(i=1-5)$;

HYS $_{\mathrm{j}}$ is the trimester within year within farm $(j=1-172)$;

Parity $_{\mathrm{k}}$ is the parity number of the sow $(\mathrm{k}=1-9)$;

Boar $_{1}$ is the random effect of the service sire $(1=1-1,418)$;

Perm $_{m}$ is the random permanent environmental effect, which accommodates repeated litter records of the same sow $(\mathrm{m}=1-7,760)$;

Animal $_{n}$ is the random additive genetic effect of the sows and their ancestors in the pedigree $(n=1-12,801)$. 
TNB is the total number born;

$\mathrm{ABW}$ is the average birth weight within litter;

VAR is the within litter variation in birth weight; and

GEST is the gestation length prior to farrowing.

Service sire effect was considered un-correlated with other effects. Co-variables used were TNB, ABW, VAR, and GEST.

HYS was used to account for structural and managerial differences between farms and changes within farms over time. Trimester within year allowed for seasonal differences within a farm and gave an average of 97.1 animals per HYS-class.

\section{Results}

\section{Description of the Data Set}

Phenotypic means, standard deviations, minimum and maximum values for the data are presented in Table 1. Average total number born is on the low side, because of the presence of pure line litters and especially of pure boar line litters. Crossbred litters D12 $(\mathrm{n}=4796, \mathrm{ABW}=1.52, \%$ litter mortality $=14.0 \%)$ and D21 $(531,1.62,13.8 \%)$ had higher birthweights and lower litter mortalities than their purebred relatives D2 (5081, 1.46, 15.9 $\%)$ and D1 (3830, 1.51, 17.0\%).

\section{Single Trait Heritabilities}

In Table 2, ratios of variance components and genetic variance, estimated with model 1 , are given for the six mortality traits and four litter traits. Heritabilities for all mortality traits were significantly different from zero. Permanent environmental effects were important for all mortality traits, and these exceeded the estimated genetic effects in magnitude in all mortality traits except for \#pre-weaning deaths. The effect of service sire on mortality traits was small, especially for \#stillborn and \%stillborn. Average birth weight had a moderate heritability $(0.30 \pm 0.02)$, and a small service sire effect $(0.02)$, indicating that the genotype of the sow determines the birth weight of the piglets. 
Table 1: Description of the data set used (16,704 litter observations).

\begin{tabular}{lcccc}
\hline & Mean & Std & Minimum & Maximum \\
\hline \#Stillborn & 0.52 & 0.96 & 0 & 9 \\
\#Pre-weaning deaths & 1.19 & 1.51 & 0 & 16 \\
\#Total deaths & 1.72 & 1.84 & 0 & 16 \\
\hline \%Stillborn & 4.85 & 9.37 & 0 & 100 \\
\%Pre-weaning mortality & 11.55 & 14.52 & 0 & 100 \\
\%Litter mortality & 15.7 & 16.3 & 0 & 100 \\
\hline Total number borm, no. & 10.55 & 3.01 & 2 & 21 \\
Average birth weight, kg & 1.51 & 0.25 & 0.65 & 2.72 \\
Variation, kg & 0.272 & 0.094 & 0.007 & .957 \\
Gestation length, days & 114.61 & 1.77 & 109 & 121 \\
\hline Parity & 2.8 & 1.84 & 1 & 9 \\
Litter birth weight, kg & 15.58 & 4.2 & 1.3 & 35.2 \\
\hline
\end{tabular}

Table 2: Ratios of variance components for mortality traits and litter traits.

\begin{tabular}{lcccc}
\hline & Heritability & $\begin{array}{c}\text { Permanent } \\
\text { Environment }\end{array}$ & $\begin{array}{c}\text { Service } \\
\text { Sire }\end{array}$ & Genetic variance \\
\hline \#Stillborn & $0.040 \pm 0.009$ & $0.093 \pm 0.012$ & $0.003 \pm 0.002$ & $0.0342 \pm 0.0075$ \\
\#Pre-weaning deaths & $0.077 \pm 0.011$ & $0.051 \pm 0.012$ & $0.015 \pm 0.003$ & $0.171 \pm 0.0026$ \\
\#Total deaths & $0.073 \pm 0.011$ & $0.079 \pm 0.013$ & $0.015 \pm 0.003$ & $0.236 \pm 0.036$ \\
\hline \%Stillborn & $0.045 \pm 0.010$ & $0.102 \pm 0.013$ & $0.005 \pm 0.002$ & $3.89 \pm 0.831$ \\
\%Pre-weaning mortality & $0.060 \pm 0.011$ & $0.084 \pm 0.013$ & $0.012 \pm 0.003$ & $12.74 \pm 2.35$ \\
\%Litter mortality & $0.062 \pm 0.011$ & $0.097 \pm 0.013$ & $0.012 \pm 0.003$ & $16.5 \pm 3.0$ \\
\hline Total number borm, no. & $0.085 \pm 0.012$ & $0.133 \pm 0.013$ & $0.020 \pm 0.004$ & $0.692 \pm 0.118$ \\
Average birth weight, kg & $0.300 \pm 0.020$ & $0.100 \pm 0.014$ & $0.023 \pm 0.003$ & $0.0168 \pm 0.0012$ \\
Variation, kg & $0.069 \pm 0.011$ & $0.039 \pm 0.012$ & $0.010 \pm 0.003$ & $0.0572 \pm 0.0088$ \\
Gestation length, days & $0.342 \pm 0.020$ & $0.072 \pm 0.016$ & $0.057 \pm 0.005$ & $0.751 \pm 0.050$ \\
\hline
\end{tabular}

Heritability of variation in birth weight was $0.07 \pm 0.01$, whilst the sire effect was virtually non existent, indicating that genetic variation was only dependent on the genotype of the sow. The service sire effect on gestation length $(0.06 \pm 0.01)$ was 
relatively high, suggesting that the genotype of the piglet influences the onset of farrowing.

Linear and quadratic correction for litter traits reduced the error variances for all mortality traits and reduced the genetic variances for the number of pre-weaning deaths and total losses (Table 3). For mortality traits expressed as percentages there was only a slight reduction in genetic variances. All linear and quadratic effects were significant in all traits, except for the linear effect of variation in birth weight.

\section{Bivariate Genetic Correlations}

In Table 4 (see end of the Chapter) correlations are presented before correction for litter traits. Genetic correlations, for \%litter mortality with \%stillborn and \%pre-weaning mortality, were significantly positive, because of the part to whole relationship that exists between them. The latter one was almost 1.0. The genetic correlation between \%stillborn and \%pre-weaning mortality was positive, but non-significant $(0.14 \pm 0.13)$.

The genetic correlation of total number born with \%stillborn was zero, but moderately positive for both \%pre-weaning mortality and \%litter mortality. For average birth weight the genetic correlation with \%stillborn was positive and with \%pre-weaning mortality negative, resulting in a low negative genetic correlation of average birth weight with \%litter mortality. Gestation length had a zero genetic correlation with stillbirth, and negative correlations with the other two mortality traits.

\section{Genetic Parameters in Each Line}

Similarities and differences were found between the lines in heritabilities and genetic correlations (Table 5, see end of the Chapter). All heritabilities for \%mortality were estimated with correction for litter traits and can be compared with the overall parameters of Table 3. The genetic correlations were estimated without correction for litter traits. In general the differences between lines in heritabilities and phenotypic correlations were relatively small. The genetic correlations for the dam lines showed more resemblance than for the sire line on one side and dam lines on the other.

The genetic correlations of total number born with \%pre-weaning mortality and $\%$ litter mortality were moderately to highly positive for the dam lines $(0.73$ and 0.60 for line $\mathrm{D} 1$ and 0.54 and 0.52 for line $\mathrm{D} 2$ ), and negative for the sire line. 
Table 3: Ratios of variance components and genetic variance for mortality traits after quadratic correction for litter traits.

\begin{tabular}{lcccc}
\hline Mortality trait & Heritability & $\begin{array}{c}\text { Permanent } \\
\text { Environment }\end{array}$ & $\begin{array}{c}\text { Service } \\
\text { Sire }\end{array}$ & $\begin{array}{c}\text { Genetic } \\
\text { Variance }\end{array}$ \\
\hline \#Stillborn & $0.045 \pm 0.009$ & $0.086 \pm 0.012$ & $0.003 \pm 0.002$ & $0.036 \pm 0.0075$ \\
\#Pre-weaning deaths & $0.049 \pm 0.010$ & $0.065 \pm 0.012$ & $0.017 \pm 0.004$ & $0.088 \pm 0.0018$ \\
\#Total deaths & $0.061 \pm 0.011$ & $0.085 \pm 0.013$ & $0.018 \pm 0.004$ & $0.148 \pm 0.026$ \\
& & & & \\
\%Stillborn & $0.046 \pm 0.010$ & $0.116 \pm 0.013$ & $0.005 \pm 0.002$ & $3.72 \pm 00.791$ \\
\%Pre-weaning mort. & $0.060 \pm 0.011$ & $0.094 \pm 0.013$ & $0.017 \pm 0.004$ & $11.07 \pm 2.08$ \\
\%Litter mortality & $0.068 \pm 0.012$ & $0.113 \pm 0.014$ & $0.018 \pm 0.004$ & $15.4 \pm 2.70$ \\
\hline
\end{tabular}

The genetic correlations of average birth weight with \%stillborn were positive for all three lines and all negative with \%pre-weaning mortality. Genetic correlations with \%litter mortality were negative, but low. Genetic correlations of gestation length with \%mortality traits were all negative except for \%stillborn in the sire line.

\section{Discussion}

\section{Data Set}

The major problem in analyzing piglet mortality has been to find a data set with 1) accurate recording of pedigree, cross fostering, birth weights, and piglet mortality and 2) sufficient numbers on which to perform genetic analyses. Blasco et al. (1995) emphasized the necessity for a large and detailed data set. The data set used here had more than 16,000 litters. All information was specially collected in the context of a selection program against piglet mortality. Induction of farrowing may have influenced the natural distribution of the trait gestation length for some litters and consequently may have resulted in biased estimates of genetic parameters. On the farm with the highest level of induction (around 50\%), the heritability of gestation length was $0.32 \pm 0.10$, which is not significantly different from the overall heritability of gestation length. It is, therefore, assumed that bias due to induction of farrowing is small. It should be noted that parameters were estimated in commercial populations under selection. Total number born 
was accounted for in the analysis. Information on finishing traits was not available in the current analyses and selection on these traits could have caused some bias in the traits considered here.

A full analysis of piglet mortality should include the direct genetic effect of the piglet, the maternal effect of the dam, the mothering ability of the nurse sow, and should take account of direct and maternal heterosis. Results presented here are a simplification of reality, because 1) cross fostering was ignored and 2) sires were included in the model without their relationship matrix and without nesting within lines. Ignoring cross fostering will result in an underestimation of the genetic parameters for the mortality traits. Sire effects were small. Piglet heterosis was accounted for by the inclusion of the line/cross effect. Estimates for \%litter mortality for the lines/crosses from model 2 were D1: $4.32 \pm$ $1.13 \mathrm{D} 21: 2.51 \pm 1.51 \mathrm{D} 12:-2.20 \pm 1.45 \mathrm{D} 2:-0.94 \pm 1.02$, indicating a heterosis advantage of, on average, $1.55 \%$ in \%litter survival.

\section{Genetic Parameters}

Heritabilities for uncorrected mortality traits are low, but significantly different from zero. The value of 0.065 of Siewerdt and Cardellino (1996) for \%litter mortality until day 21 is in good agreement with the present result $(0.07 \pm 0.01)$, using similarly defined litter traits. In their review, Rothschild and Bidanel (1998) gave an average of 0.05 for \%preweaning survival, based on 16 publications. This compares well with the current estimate of $0.06 \pm 0.01$. In general, litter traits, fitted as linear and quadratic covariates, were seen to have a highly significant effect on \%mortality. The linear and quadratic correction method is debatable, since the litter traits are genetically correlated (Table 4) and since a linear/quadratic relationship might not be a good description for each litter effect. However, after correction for these litter traits, estimates of genetic variance remained similar for mortality traits expressed as percentages and for \#stillborn; the error terms decreased, and heritabilities were marginally increased. Heritabilities for \#total mortality and \#pre-weaning deaths were slightly reduced in size. It is concluded from this study that genetic variation in mortality traits exists independently of total number born, average birth weight, variation in birth weight, and gestation length.

Johnson et al. (1999) reported results of their selection experiment for total number born, with a very good genetic trend in total number born $(+0.21 \mathrm{piglet} / \mathrm{litter} /$ generation $)$, but not in total number at weaning $(-0.03 \mathrm{piglet} /$ litter/generation). Litter mortality 
increased at a rate similar to that in total number born giving a slightly negative trend for piglets weaned per litter. The genetic correlation of total number born with uncorrected $\%$ litter mortality found in the present study was $0.38 \pm 0.11$ (Table 4).

Differences in genetic parameters may exist between lines due to differences in limiting underlying biological factors. If uterine capacity is limiting litter size, heritability for litter size will be different than when ovulation rate is limiting. The genetic correlations between \%litter mortality and litter size was considerably higher in the dam lines than in the overall data set. The genetic correlation in the sire line was negative, indicating that prenatal mortality could be a limiting factor for litter size in this line. If post-natal survival has a positive correlation with pre-natal survival this would be the case.

Gestation length between the two dam lines differed with two days, a highly significant difference. The sire line was intermediate. Line D1 originated from Pietrain populations and had the higher gestation length. The genetic correlations of gestation length with the three mortality traits calculated per line (Table 5) were, however, in very good agreement with the overall values (Table 4)

The genetic correlation of average birth weight and \%stillborn was positive in the overall analysis as well as in the individual lines. The genetic correlation of average birth weight with pre-weaning survival was negative, overall and in the three lines. This resulted in a negative, but low genetic correlation for average birth weight and \%litter mortality. Different authors (Fahmy et al., 1978, English and Wilkinson, 1982, and, Van der Lende and de Jager, 1991) have discussed the shape of the curve describing the phenotypic relationship between individual birth weight and mortality, but all agree on the negative sign of the correlation. In the present analysis average birth weight per litter was analyzed. Average birth weight was positively correlated $\left(r_{\mathfrak{g}}=.47\right)$ with within litter variation in birth weight (Table 4), whilst within litter variation is genetically positively correlated with the mortality traits, except in the sire line. A possible mechanism could be that selection against piglet mortality yields more uniform litters, with a lower number of heavy piglets and therefor with a lower average birth weight. Lee and Haley (1995) analyzed farrowing to weaning performance in Meishan and Large White pigs and their crosses. They found similar or higher survival rates for Meishan piglets with much lower birth weights compared to Large White piglets or much improved survival rates in the Meishan when correction for birth weight was applied. Greater uniformity in birth weights 
and a higher degree of maturity at birth may play a role in survival. In the current analysis, \%litter mortality had significant genetic correlations with variation in birth weight $(0.32 \pm$ $0.11)$ and gestation length $(-0.36 \pm 0.09)$. A combination of more uniform piglets with a longer gestation length seems to be favorable for survival with variation in birth weight in the sire line as the exception.

The genetic correlation between \%stillborn and \%pre-weaning mortality was low in the overall data set, 0.14 (Table 4), but higher in the individual lines (Table 5). Selection against \%stillborn will result in a small correlated response in pre-weaning survival.

\section{Service Sire Effect}

The low influence found of the service sire on all the mortality and litter traits, except for gestation length, is interesting. In \%litter mortality, the service sire effect of 0.02 was small, but relatively more important than in total number born, which has a lower heritability. An analysis investigating the genotype of the piglets appears, therefore, to be worthwhile. It is mainly the genotype of the dam that determines the birth weight of the piglet and not so much the genotype of the piglet. This is again in agreement with Lee and Haley (1995). The service sire effect on \%stillborn was very small $(0.005)$.

\section{Conclusions}

Heritabilities for \#total deaths, \%litter mortality and their component traits were significantly greater than zero.

The genetic variance in mortality is independent of birth weight, total number born, variation in birth weight, and gestation length.

A heritability of 0.068 for \%litter mortality in the single trait analysis with a genetic variance of 15.4 is promising for selection.

Selection for increased average birth weight to decrease piglet mortality might result in decreased total number born, but will not markedly increase survival.

\section{Implications}

Many breeding programs select for increased litter size. This may lead to increased mortality. Direct selection against piglet mortality is feasible given a proper information structure. Recording of- and selection against- \%stillborn are the minimum practical 
requirements of such a scheme. Inclusion of gestation length in the selection index can help to maintain maturity of the piglets in selection programs aimed at increased litter size.

\section{Literature Cited}

Bedrijfsvergelijking SIVA software BV, 1999. Kengetallenspiegel. Available at: http://www.siva.nl/nl/result/rzlan99.htm. Accessed at: July 3, 2000.

Blasco, A., J. P. Bidanel, and C.S. Haley. 1995. Genetics and Neonatal Survival. In: M.A. Varley (ed.) The Neonatal Pig. Development and Survival. pp 17-38. CAB International, Wallington, Oxon, UK.

English, P.R., and V. Wilkinson. 1982. Management of the sow and litter in late pregnancy and lactation in relation to piglet survival and growth. In: D.J.A. Cole and G.R. Foxcroft (eds.) Control of pig reproduction. pp 479-506. Butterworths Scientific, London.

Fahmy, M. H., W.B. Holtmann, T. M. MacIntyre, and J.E. Moxley. 1978. Evaluation of piglet mortality in 28 two-breed crosses among eight breeds of pigs. Anim. Prod. 26: $277-285$.

Gilmour A.R., B.R. Cullis, S. J. Welham, and R. Thompson. 1999. ASREML. NSW Agriculture, occasional publication.

Herpin, P., J. Le Dividich, and N. Amaral. 1993. Effect of selection for lean tissue growth on body composition and physiological state of the pig at birth. J. Anim. Sci. 71:2645.

Johnson, R.K., M. K.Nielsen, and D. S. Casey. 1999. Responses in ovulation rate, embryonal survival, and litter traits to 14 generations of selection to increase litter size. J. Anim. Sci. 77: 541-557.

Kerr, J.C., N.D. Cameron. 1995. Reproductive performance of pigs selected for components of efficient lean growth. Anim. Sci. 60: 281-290.

Lee, G.J., and C.S. Haley. 1995. Comparative farrowing to weaning performance in Meishan and Large White pigs and their crosses. Anim. Sci. 60: 269-280.

McKay, R.M. 1993. Preweaning losses of piglets as a result of index selection for reduced backfat thickness and increased growth rate. Can. J. Anim. Sci. 73: 437-442.

PigCHAMP database, 1998. Swine data management's Pigchamp record service. Available at: http://www.netins.net/showcase/swinedata. Accessed July 3, 2000. 
Roehe, R., and E. Kalm. 2000. Estimation of genetic and environmental risk factors associated with pre-weaning mortality in piglets using generalized linear mixed models. An. Sc. 70: 227-240.

Rothschild, M.F., and J.P. Bidanel.1998. Biology and genetics of reproduction. In: The genetics of the pig (Ed. M.F. Rothschild \& A.Ruvinski), pp. 313-343. CAB International, Wallingford, Oxon, UK

Siewerdt, F., and R.A.Cardellino, 1996. Genetic parameters of piglet mortality from birth to 21 days of age in the Landrace breed. Revta Soc. Bras. Zootéc. 25, 902-909.

Van der Lende, T., and D. de Jager. 1991. Death risk and pre-weaning growth rate of piglets in relation to the within litter weight distribution at birth. Livest. Prod. Sci. 28:73-84.

Zaleski, H.M., and R.R. Hacker. 1993. Variables related to the progress of parturition and probability of stillbirth in swine. Can. Vet. J. 34: 109-113. 


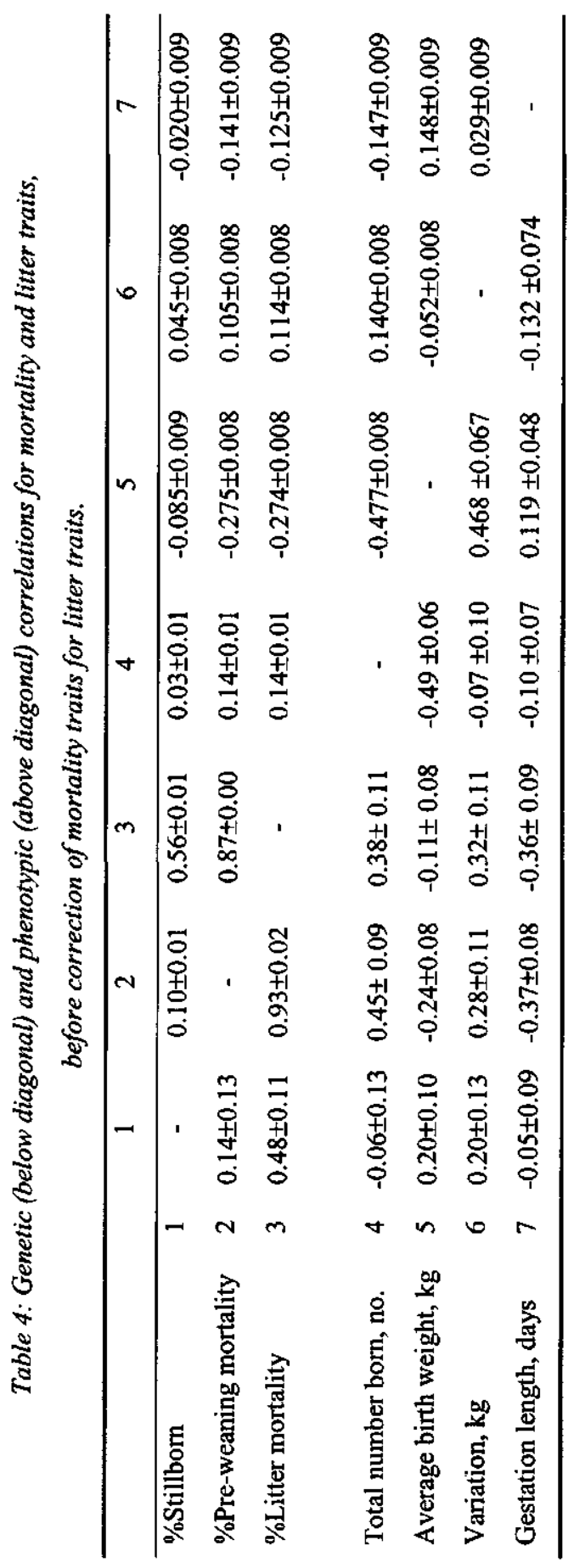




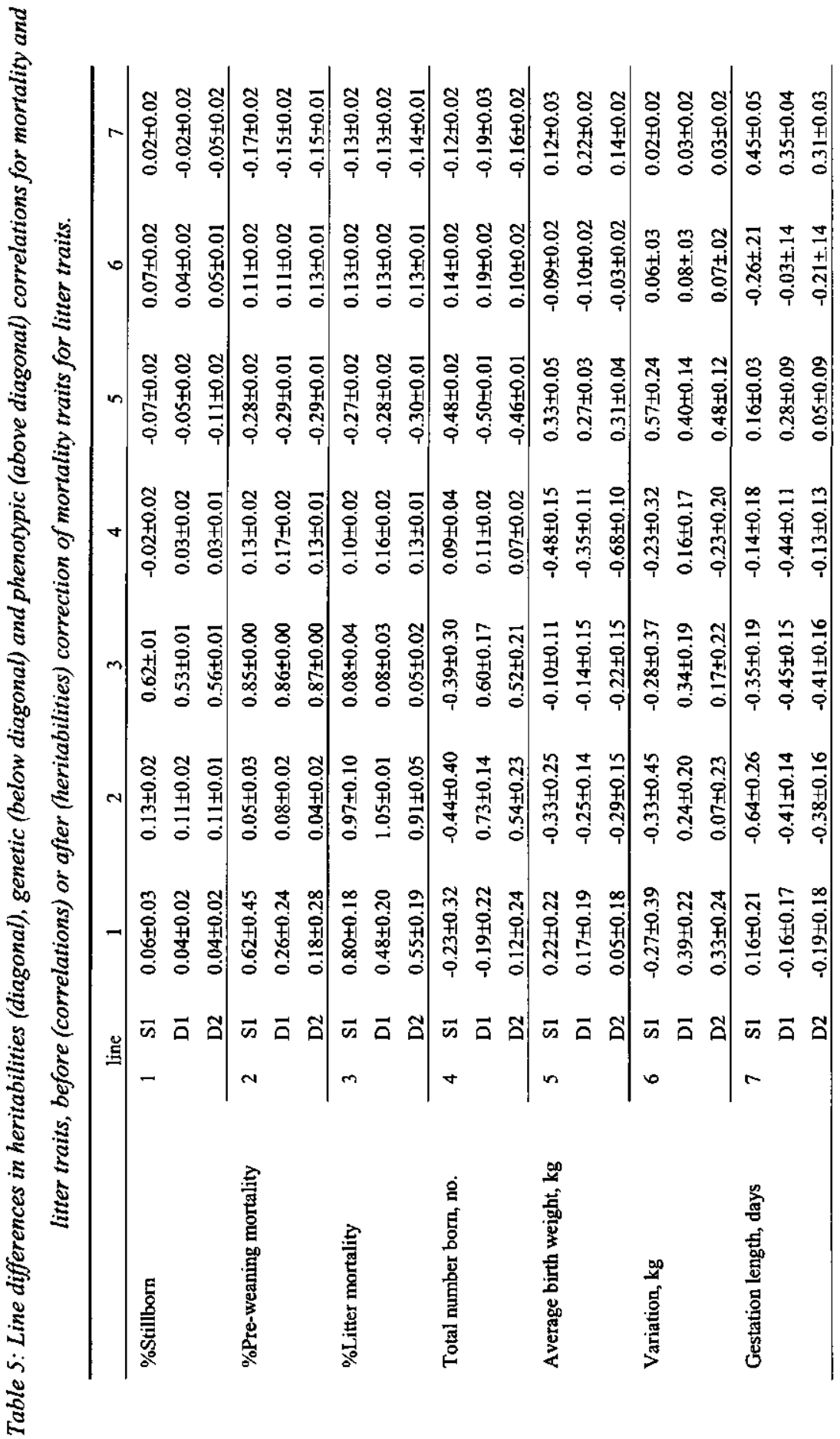


Piglet losses were classified as:

(c) unknown deaths -piglets that died without any apparent cause;

-..

McKay (1993) 


\title{
2 Direct, maternal and nurse sow genetic effects on

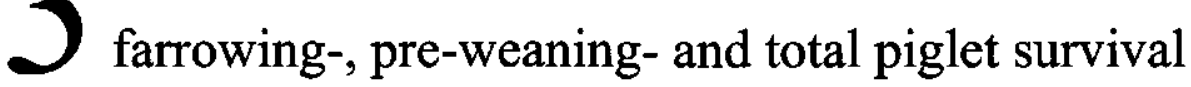

\begin{abstract}
Peri- and postnatal survival data, including birth weights and cross-foster information from two line/farm combinations with 33,717 and 29,200 piglets respectively, were analyzed to find the best genetic model to describe piglet survival. This was done in terms of direct (piglet), maternal and nurse- sow genetic effects, maternal to cover uterine quality and nurse sow to cover mothering ability. The two component traits, farrowing survival and pre-weaning survival - and birth weight, the most important factor for survival - were similarly analyzed. As fixed effects, Year/Season, cross, parity, birth weight in classes of $100 \mathrm{~g}$, litter size as such, and sex were included in the analyses. Models combining the different genetic effects were compared on the basis of the loglikelihood. A maternal/nurse sow model fitted the data best for pre-weaning survival, a direct/maternal model for birth weight, a direct model for farrowing survival in the dam line and a direct/maternal model for farrowing survival in the sire line. Including nurse sow effect in a model for piglet survival as a whole gave erratic results, making it difficult to define an optimal model. Estimated heritabilities for pre-weaning survival, measured on the binary scale, in the dam line were $0.02 \pm 0.005$ for both maternal and nurse sow effects. Heritabilities for birth weight were on average $0.04 \pm 0.01$ for the direct effect and $0.20 \pm 0.03$ for the maternal effect.
\end{abstract}

Keywords: Piglet Survival, Genetic Parameters, Birth Weight; Maternal Effect, Stillborn, Pre-weaning Mortality

\section{Submitted:}

Knol, E.F., B.J. Ducro, J.A.M. van Arendonk, and T. van der Lende. Direct, maternal and nurse sow genetic effects on farrowing-, pre-weaning-and total piglet survival. 


\section{Introduction}

Selection for litter size might very well increase piglet mortality (Johnson et al., 1999). Heritability estimates for piglet mortality and its component traits are considered low (Lamberson and Johnson, 1984, Siewerdt and Cardellino, 1996, Johnson et al, 1999). Genetic parameter estimation is difficult, because of the binary observation of the trait and the high environmental effects. Large and well-defined data sets are needed, but not abundantly available.

Total piglet mortality can be defined as the sum of peri- and postnatal mortality or as the sum of stillborn and pre-weaning mortality or as its complement, piglet survival. Analysis of piglet survival can be on the trait itself or on its two component traits, farrowing survival and pre-weaning survival. A genetic analysis of farrowing survival needs to consider the genotypes of piglet and dam. An analysis of pre-weaning survival needs the addition of the genotype of the nurse sow. Most piglets are not cross-fostered and remain with their dam; in these situations the dam is the nurse sow. This complicates the separation of variance into dam and nurse sow effects. Estimation of dam and nurse sow effects is only possible in situations in which relatively many piglets are crossfostered. Cross-fostering procedures under commercial management are variable and vary from little use of cross-fostering on farms with low litter size to a lot of crossfostering in large units where complete standardization on the basis of birth weight is the goal. On average in these situations some $10 \%$ of all piglets are cross-fostered, with different strategies applied to increase survival chances for piglets. One is to combine light piglets from large litters into new litters and entrust them to a sow with a good expectation for mothering ability. Another is to place the heaviest piglets from new litters into older litters with a smaller number of piglets. Standardization in terms of numbers is very common. A genetic analysis of survival should differentiate carefully between quality of the piglet and mothering ability of the sow.

Birth weight is regarded to be the most important factor for piglet survival. Several authors (e.g. Kerr and Cameron, 1995; Roehe and Kalm, 2000) suggest selection for increased birth weight rather than direct selection for piglet survival, which has a lower heritability. A genetic analysis of piglet survival should correct for this effect of birth weight in order to investigate the possibilities of genetic improvement of piglet survival apart from the birth weight effect. 
The aim of this study was to find the best models for piglet survival traits and birth weight in terms of combinations between direct, maternal and nurse sow genetic effects and to estimate genetic parameters for selection for improved survival.

\section{Material and methods}

Data

Data were collected on two farms in the Netherlands. The first was a multiplication farm with on farm production of female replacements. All sows were from the commercial dam line D2 and most of them were inseminated with semen from dam line D1 boars to produce crossbred D12 piglets. The second farm was a nucleus farm for boar production, sire line S2 with on farm production of female replacements. Boars used on the boar nucleus originated approximately $50 \%$ to the farm itself. All matings were done by AI. Line and farm are fully confounded. 'Dam line' and 'sire line' will be used to address the farm/line combinations.

In the dam line data was collected from 1993.4 (fourth trimester of 1993) to 1999.3: 747 dams with, on average, 45 piglets per sow, 341 sires with 99 piglets per sire. In the sire line data collection was from 1994.4 to 1999.3: 1038 dams with 28 piglets and 165 sires with 177 piglets each. In both lines a pedigree dating back to 1982 was available and in both lines no selection on survival was performed, except for the occasional phenotypic culling, until the start of the data collection, when piglet survival became part of the breeding goal. Sows were kept under commercial Dutch conditions and sows were mated randomly to boars. To obtain a low generation interval, replacement rate was high in the sire line, compared to Dutch standards, as can be seen in the numbers of piglets per dam, compared to the dam line ( 28 vs. 45 per sow).

The registration protocol for new-born litters involved the weighing of all piglets within 24 hours after farrowing, including the stillborn, the registration of cross-fostering and the registration of piglet mortality with date and cause of death. For further details on lines see Leenhouwers et al. (1998).

\section{Statistical analysis}

A model for the analysis of piglet survival can be divided into a fixed effects part and a genetic part. The fixed effect part was, in matrix notation: 
$\mathbf{y}=\mathbf{X} \boldsymbol{b}+e$,

where $y$ is the vector of the observations on the piglets, $X$ the incidence matrix and $\boldsymbol{b}$ a solution vector for the fixed effects. Differences in piglet survival can exist between years and seasons, caused by changes in barn infrastructure, availability of labor and temperature, among others. Effect of Year/Season was expressed as quarters per year (YS). A random litter effect can account for infectious diseases like diarrhea and incidentals like diseased udders, which affect all piglets in a litter. Further potential fixed effects are birth weight, variation in birth weight, litter size, sex, line/cross, and parity. Birth weight has a direct effect: piglet survival decreases with decreasing birth weight (Bereskin, 1973). The relation between birth weight and survival is not linear. Variation in birth weight is related to competition among littermates. Litter size was defined as total born, excluding mummified piglets and excluding non-fresh stillborn piglets. An increase in litter size decreases survival; this could be an indirect effect of birth weight, or, to be more specific, it could reflect the impact of uterine crowding. Males seem to have a lower chance of survival. Heterosis has a positive influence on traits with a low heritability, in particular on fitness; in the dam line data set the majority of the piglets were crossbred and might therefore benefit from heterosis. Finally, farrowing survival decreases with parity, possibly explained by increasing litter size - causing crowding and prolonged farrowing -, decreasing birth weight and a gradually decreasing quality of the uterus.

This resulted in the following fixed effect model (ignoring subscripts) for farrowing-, pre-weaning and piglet survival:

$$
\mathrm{YS}+\text { cross }+ \text { parity }+ \text { sex }+ \text { birth weight }+ \text { litter size }+e
$$

Birth weight entered the analysis in classes of $100 \mathrm{~g}$, because of the expected non-linear nature of birth weight. Litter size was used as such. For birth weight the fixed effect model was:

$$
\mathrm{YS}+\text { litter + sex + parity + litter size + e }
$$

Seven different models were used to determine the best genetic model. Model 1, 2, and 3 are single genetic effect models for direct, maternal, and nurse sow effects, respectively. Model 4 is the direct/maternal model. Model 5 combines the piglet direct genotype with the mothering ability of the nurse sow. Model 6 includes maternal- and 
nurse sow effects. Model 7 includes all three animal effects. Inclusion of the nurse sow effect in the models for farrowing survival and birth weight has no biological meaning and these analyses were skipped. In summary:

$$
\begin{aligned}
& \text { Model 1: } \quad \mathbf{y}=\mathbf{X} b+\mathbf{Z}_{1} a+\quad \mathbf{Z}_{4} \text { lit }+e(\text { (4 traits) } \\
& \text { Model 2: } \quad \mathbf{y}=\mathbf{X b}+\quad \mathrm{Z}_{2} m+\quad+\mathrm{Z}_{4} \text { lit }+\boldsymbol{e} \text { (4 traits) } \\
& \text { Model 3: } \quad \mathrm{y}=\mathrm{X} b+\quad+\mathrm{Z}_{3} f+\mathrm{Z}_{4} \text { lit }+e \text { (2 traits) } \\
& \text { Model 4: } \quad \mathbf{y}=\mathbf{X} b+\mathbf{Z}_{1} a+\mathbf{Z}_{2} m+\quad+\mathbf{Z}_{4} \text { lit }+\boldsymbol{e} \text { (4 traits) } \\
& \text { Model 5: } \quad \mathbf{y}=\mathbf{X} b+\mathbf{Z}_{1} a+\quad \mathbf{Z}_{3} f+\mathbf{Z}_{4} \text { lit }+e \text { (2 traits) } \\
& \text { Model 6: } \quad \mathbf{y}=\mathbf{X} b+\quad+\mathbf{Z}_{2} m+\mathbf{Z}_{3} f+\mathbf{Z}_{4} \text { lit }+e \text { (2 traits) } \\
& \text { Model 7: } \quad \mathbf{y}=\mathbf{X} b+\mathbf{Z}_{1} a+\mathbf{Z}_{2} m+\mathbf{Z}_{3} f+\mathbf{Z}_{4} \text { lit }+e(2 \text { traits })
\end{aligned}
$$

All analyses were single trait, between parentheses is the number of different traits analyzed. Farrowing survival and birth weight were not analyzed with models including nurse sow effect.

The random effects: $\boldsymbol{a}$ is a vector of direct genetic effects, $\boldsymbol{m}$ is a vector of maternal genetic effects, $f$ is a vector of nurse sow genetic effects. Lit is a vector of common environmental effects for all piglets within a litter at birth and $e$ is a vector of residual effects. and $\mathbf{Z}_{1}, \mathbf{Z}_{2}, \mathbf{Z}_{3}$, and $\mathbf{Z}_{4}$ are incidence matrices relating observations to random effects $a, m, f$, and $l i t$, respectively.

The covariance structure for the random effects in Model 7, the most complex model, was:

$\mathrm{V}=\left[\begin{array}{l}a \\ m \\ f \\ l i t \\ e\end{array}\right] *\left[\begin{array}{lllll}\mathbf{A} \sigma_{\mathrm{a}}{ }^{2} & \mathbf{A} \sigma_{\mathrm{am}} \mathbf{A} \sigma_{\mathrm{af}} & \mathbf{0} & \mathbf{0} \\ \mathbf{A} \sigma_{\mathrm{am}} & \mathbf{A} \sigma_{\mathrm{m}}{ }^{2} \mathbf{A} \sigma_{\mathrm{mf}} & \mathbf{0} & \mathbf{0} \\ \mathbf{A} \sigma_{\mathrm{af}} & \mathbf{A} \sigma_{\mathrm{mf}} & \mathbf{A} \sigma_{\mathrm{f}}{ }^{2} & \mathbf{0} & \mathbf{0} \\ \mathbf{0} & 0 & \mathbf{0} & \mathbf{I} \sigma_{\mathrm{lit}}{ }^{2} & \mathbf{0} \\ \mathbf{0} & \mathbf{0} & \mathbf{0} & \mathbf{0} & \mathbf{I} \sigma_{\mathrm{e}}{ }^{2}\end{array}\right]$

where $\sigma_{\mathrm{a}}{ }^{2}$ is the direct genetic variance, $\sigma_{\mathrm{m}}{ }^{2}$ the maternal genetic variance, $\sigma_{\mathrm{f}}{ }^{2}$ the genetic variance due to the nurse sow effect, $\sigma_{\mathrm{lit}}{ }^{2}$ the part of the permanent environmental effects explained by the litter at birth effect and $\sigma_{e}{ }^{2}$ the error variance. Relationships between all 
animals with records and parents of animals with records were used in building $\mathbf{A}$. I is the identity matrix.

The mixed model equations for Model 7 are as follows:

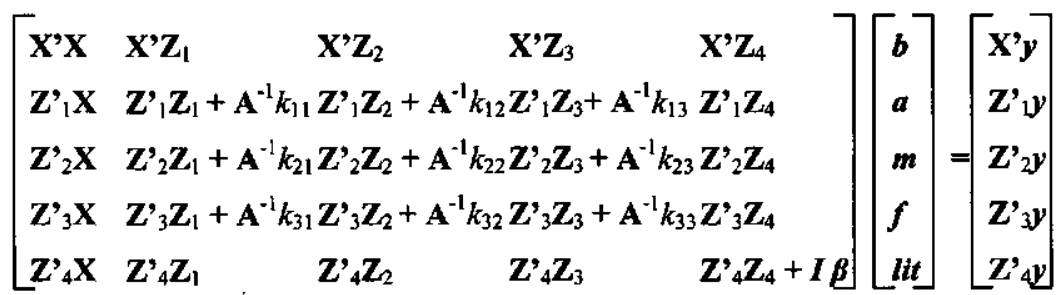

where

$\left[\begin{array}{ll}k_{11} k_{12} & k_{13} \\ k_{21} k_{22} & k_{23} \\ k_{31} k_{32} & k_{33}\end{array}\right]=\left[\begin{array}{lll}\sigma_{\mathrm{a}}^{2} & \sigma_{\mathrm{am}} & \sigma_{\mathrm{af}} \\ \sigma_{\mathrm{am}} & \sigma_{\mathrm{m}}{ }^{2} & \sigma_{\mathrm{mf}} \\ \sigma_{\mathrm{af}} & \sigma_{\mathrm{mf}} & \sigma_{\mathrm{f}}^{2}\end{array}\right]{ }^{-1} \sigma_{\mathrm{e}}^{2}$

and $\beta=\sigma_{\mathrm{e}}{ }^{2} / \sigma_{\mathrm{lit}}{ }^{2}$. The total phenotypic variance $\sigma_{\mathrm{p}}{ }^{2}$ is then equal to:

$\sigma_{\mathrm{a}}^{2}+\sigma_{\mathrm{m}}^{2}+\sigma_{\mathrm{f}}^{2}+\sigma_{\mathrm{am}}+\sigma_{\mathrm{af}}+\sigma_{\mathrm{mf}}+\sigma_{\mathrm{lit}}^{2}+\sigma_{\mathrm{e}}^{2}$

Analyses were performed with the routines of ASREML as described by Gilmour (1999). ASREML is a statistical package, which handles, among many other models, mixed models and provides estimates for genetic parameters, such as heritabilities and genetic correlations. Survival traits were analyzed as continuous variables and not as binary.

\section{Results}

\section{Descriptive statistics}

Litter size was lower in sows of the sire line compared to the purebred litters of the dam line (Table 1), as was piglet survival, despite a somewhat higher birth weight in the sire line. Crossbred piglets in the dam line showed a $50 \mathrm{~g}$ higher birth weight and a $1.7 \%$ increase in piglet survival as compared to purebred piglets from $\mathrm{D} 2$ sows.

Cross-fostering in the dam line $(17.8 \%)$ was much higher than in the sire line $(6.3 \%)$ (Table 1). Cross-fostered piglets in the dam line had a pre-weaning survival of $91.3 \%$ as compared to $88.0 \%$ for the non-cross-fostered piglets, while birth weight was on average $80 \mathrm{~g}$ lower (Table 2). In the sire line, cross-fostered piglets had a lower survival, but their 
weight was considerably lower than the non-cross-fostered piglets. In both lines, crossfostered piglets were transferred on average from the larger, more variable litters. In the dam line, more boar piglets were cross-fostered; while in the sire line, more female piglets were cross-fostered.

This is associated with the breeding function of the farms. As much as possible animals with no future function in replacement or sales are used for crossfostering.

Table 1: Phenotypic statistics for pure line (D2 and S2) and crossbred (D12) piglets and their litters.

\begin{tabular}{|c|c|c|c|c|c|c|c|c|}
\hline Piglet traits & $\begin{array}{l}\text { Line/ } \\
\text { Cross }\end{array}$ & $\begin{array}{l}\text { No. of } \\
\text { obs. }\end{array}$ & $\begin{array}{c}\text { Sex } \\
\text { Ratio }^{b}\end{array}$ & $\begin{array}{c}\text { Cross- } \\
\text { foster } \\
\%\end{array}$ & $\begin{array}{c}\text { Birth } \\
\text { weight } \\
(\mathbf{k g})\end{array}$ & $\begin{array}{c}\text { Farrowing } \\
\text { survival } \\
(\%)\end{array}$ & $\begin{array}{l}\text { PWS }^{2} \\
(\%)\end{array}$ & $\begin{array}{l}\text { Piglet } \\
\text { surviv } \\
\text { al (\%) }\end{array}$ \\
\hline \multirow[t]{3}{*}{ Dam line } & D2 & 2095 & 52.4 & 13.7 & 1.39 & 92.0 & 87.6 & 80.6 \\
\hline & D12 & 31622 & 52.0 & 18.1 & 1.44 & 92.7 & 88.7 & 82.3 \\
\hline & All & 33717 & 52.1 & 17.8 & 1.44 & 92.7 & 88.7 & 82.2 \\
\hline Sire line & S2 & 29200 & 52.3 & 6.3 & 1.42 & 93.2 & 85.0 & 79.2 \\
\hline Litter traits & $\begin{array}{l}\text { Linel } \\
\text { Cross }\end{array}$ & & $\begin{array}{l}\text { No. of } \\
\text { Litters }\end{array}$ & Parity & $\begin{array}{c}\text { Litter } \\
\text { Size }\end{array}$ & \multicolumn{3}{|c|}{$\begin{array}{l}\text { Variation in birth } \\
\text { weight }^{\mathrm{c}}(\mathrm{kg})\end{array}$} \\
\hline \multirow[t]{3}{*}{ Dam line } & $\mathrm{D} 2$ & & 173 & 3.92 & 12.10 & \multicolumn{3}{|c|}{0.311} \\
\hline & D12 & & 2647 & 4.58 & 12.02 & \multicolumn{3}{|c|}{0.309} \\
\hline & All & & 2820 & 4.54 & 12.02 & \multicolumn{3}{|c|}{0.309} \\
\hline Sire line & S2 & & 2874 & 2.68 & 10.17 & \multicolumn{3}{|c|}{0.277} \\
\hline
\end{tabular}

${ }^{a}$ Pre-weaning survival; ${ }^{b}$ Percentage of males; ${ }^{\circ}$ W ithin litter standard deviation

Table 2: Phenotypic statistics for non-cross-fostered and cross-fostered piglets and their birth litter information.

\begin{tabular}{cccccccccc}
\hline Farm & $\begin{array}{c}\text { Cross- } \\
\text { fostering }\end{array}$ & $\begin{array}{c}\text { No. of } \\
\text { piglets }\end{array}$ & $\begin{array}{c}\text { Sex } \\
\text { ratio }^{6}\end{array}$ & $\begin{array}{c}\text { Birth } \\
\text { weight } \\
(\mathrm{kg})\end{array}$ & $\begin{array}{c}\mathrm{PWS}^{\mathrm{a}} \\
(\%)\end{array}$ & $\begin{array}{c}\text { No. of } \\
\text { litters }\end{array}$ & $\begin{array}{c}\text { Parity } \\
\text { Litter } \\
\text { Size }\end{array}$ & $\begin{array}{c}\text { Variation in } \\
\text { birth weight } \\
\text { c } \\
\text { (kg) }\end{array}$ \\
\hline Dam line & No & 27703 & 51.6 & 1.45 & 88.0 & 1000 & 3.28 & 10.31 & 0.281 \\
& Yes & 6014 & 54.2 & 1.37 & 91.3 & 1820 & 5.23 & 12.97 & 0.324 \\
& No & 27349 & 53.0 & 1.44 & 85.1 & 1937 & 2.37 & 9.37 & 0.269 \\
& Yes & 1851 & 41.3 & 1.23 & 83.5 & 937 & 3.33 & 11.82 & 0.295 \\
\hline
\end{tabular}

${ }^{a}$ Pre-weaning survival; ${ }^{b}$ Percentage of males; ${ }^{c}$ Within litter standard deviation 


\section{Fixed effects}

All fixed effects were estimated within line with the fixed effect model without inclusion of random effects. The most significant effect on piglet survival was birth weight. Estimates are shown in Figure 1. Visual appraisal of this Figure suggests two straight lines, one from 500 to $800 \mathrm{~g}$ and one from 1300 to $2000 \mathrm{~g}$. These lines cross at a point around $1000 \mathrm{~g}$ in the dam line and around $1100 \mathrm{~g}$ in the sire line. Birth weight was therefore included in the model as a class variable instead as a linear or other function.

Including variation in birth weight in the model did not give a significant reduction in error variance. The relation of litter size with survival traits was positive and significant. Survival of piglets born in small litters ( $<5$ piglets) was considerably lower than average. This was after correction for birth weight and all other effects. In the normal space of observation ( 6 to 16 piglets) the relationship was more or less linear, with an increase in survival of around $0.5 \%$ per piglet. Sex of the piglet was important for its survival; survival probability for a female piglet was $2.2 \pm 0.4 \%$ higher in the dam line and $4.2 \pm$ $0.4 \%$ in the sire line. The higher birth weight of boar piglets eliminates a large part of this difference, however. The difference in piglet survival between crossbred and purebred piglets was not significant, suggesting an absence of heterosis or a lower direct genetic effect in the sow line. The effect of parity on piglet survival was negative in the dam line and particularly for farrowing survival (Figure 1c).

\section{Heritabilities and genetic correlations}

Based on log-likelihood values in Table 3 for birth weight in both lines, the direct/maternal model (Model 4) fitted the data significantly $(\mathrm{P}<0.01)$ better than a maternal model (Model 2) and certainly better than the direct model (Model 1) in both lines. Maternal heritabilities were 0.22 and 0.18 for the dam line and sire line, respectively, and direct heritabilities 0.03 and 0.06 . Genetic correlations were nonsignificant and had a different sign for the dam line and sire line, respectively. It was concluded that the sow, with a significant contribution from the piglet, had the greatest effect on the birth weight of piglets.

The results of the farrowing survival analysis differed between the two lines (Table 4). For the dam line the direct model was preferred, while for the sire line the maternal and direct/maternal models described the data equally well. It was concluded that farrowing survival had low, but significant, genetic components. These effects were mainly direct in 
nature in the dam line and mainly maternal in the sire line. This would indicate that different processes are limiting farrowing survival in the dam line and in the sire line.

Results of the pre-weaning survival analysis are somewhat difficult to interpret statistically, since comparison of models on the basis of log-likelihood is only possible if one model is a sub-model of the other.
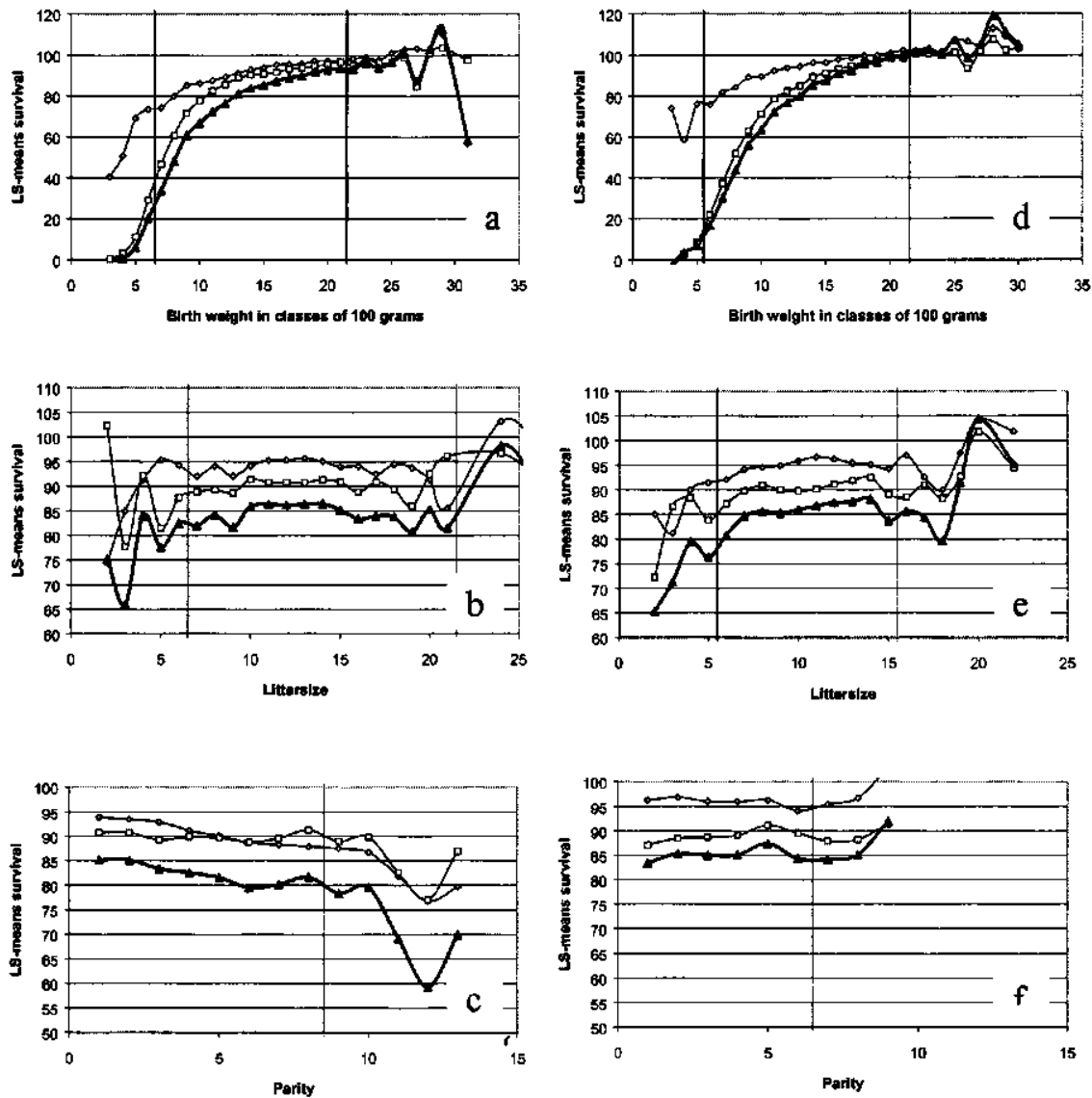

Figure 1: Influence of birth weight $(a, d)$, litter size $(b, e)$ and parity $(c, f)$ on farrowing- (- -), pre-weaning - (- -) and piglet survival (- -) in the dam line (ac) and in the sire line (d-f). Estimates between vertical lines $(a, b, d, e)$ or left of the vertical line ( $c$ and $f$ ) have a stde for piglet survival between $-2 \%$ and $2 \%$.

In the sire line Model 7 had a significantly better fit than Models 1-5, while Model 6, the maternal/nurse-sow model, had an equally good fit as model 7 (Table 5). In the dam line Model 7 was significantly better than Models 2-5, while Model 1 fitted the data similarly 
to Model 7. Model 6, however, was significantly better than Models 1 and 7. A direct comparison between Models 1 and 6 is not possible, since direct effect is not part of Model 6. Using the comparison with Model 7, it can be concluded indirectly, that Model 6 is significantly better than Model 1 . On the basis of these results pre-weaning survival can best be described with Model 6, the combination of uterine quality of the dam and mothering ability of the nurse sow.

Piglet survival was defined as the combination of farrowing survival and pre-weaning survival. In Table 6 the log-likelihood and variance component estimates are given. In both lines it can be seen that models ignoring the nurse sow effect had a significantly lower likelihood than Models 3, 5 and 6, which included the nurse sow effect. Of these last three models, Model 6 had the highest likelihood in both lines, a result similar to the result of pre-weaning survival.

\section{Discussion}

All analyses have been done twice, once in a dam line and once in a sire line. Dam line and sire line were confounded with farm. Differences in results might be due to line differences or to differences between farms, fi in crossfostering strategy. In the sire line litter size total born was 10.17 and crossfostering $6.3 \%$ and in the dam line these figures were 12.02 and $17.8 \%$, respectively. In our opinion these two, rather different, situations give a clear indication of genetic parameters for piglet survival and birth weight in general.

Of particular interest are the genetic correlations between birth weight and survival traits. Scope of this article was to find the best models to describe the survival traits and to check if a direct -maternal model is indeed the best model to describe birth weight. A proper genetic correlation analysis would involve two animal effects on the birth weight side and two or even three animal effects on the survival side, giving 4 or 6 genetic correlations with the associated interpretation difficulties. A simplified analysis was carried out, in which both survival and birth weight were modeled with the direct effect only, and birth weight and variation in birth weight were dropped from the original survival model. This yielded values of $-0.05 \pm 0.11$ and $-0.49 \pm 0.11$ for the genetic correlation between farrowing survival and birth weight for the dam line and the sire line, respectively. And $0.18 \pm 0.10$ and $0.32 \pm 0.13$ for pre-weaning survival and birth weight, respectively and $0.10 \pm 0.11$ and $0.02 \pm 0.12$ for piglet survival. The effect of birth weight 
on farrowing survival was negative, on pre-weaning survival positive and the net result on piglet survival almost zero. But again, a dedicated analysis would be worth while.

\section{Influence of fixed effects on survival}

Birth weight is recognized as the most important factor for piglet survival. Several authors have described the non-linear relation between the two. Roehe and Kalm (2000) presented $40 \%$ pre-weaning mortality below a birth weight of $1.0 \mathrm{~kg}, 15 \%$ between 1.0 and $1.2 \mathrm{~kg}$ and $7 \%$ above $1.6 \mathrm{~kg}$. Fireman and Siewerdt (1997) estimated Gompertz curves for pre-weaning mortality, which fitted their data quite nicely. In the present analysis no assumptions were made about the relationship between birth weight and survival. Pre-weaning survival estimates per class of $100 \mathrm{~g}$ birth weight were in very good agreement with the data of Fireman and Siewerdt (1997). The influence of litter size, corrected for birth weight and parity, was significant and positive, but not very important. Small litters seemed to have reduced survival rates, as reported by Kerr and Cameron (1995). The effect was most obvious in the sire line; however, the number of small litter sizes observed was low. The cause-effect relation is questionable. Perhaps, survival differences are the cause for small litters. If anything, the relation between litter size and piglet survival in the sire line was positive in general and positive in the area of larger numbers of observations, too

An increase in parity did not influence pre-weaning survival in either line. It did influence farrowing survival in the dam line, but not in the sire line. An increase in the number of stillborn with parity, corrected for birth weight and litter size, has been reported in similar data by Leenhouwers et al. (1998).

Correction of survival parameters for parity is allowed, since parity can be considered as an environmental factor. Litter size and especially birth weight are more difficult, since birth weight is the most important factor for survival and significantly heritable. Common environment was defined in terms of the dam and included the possible influence of gestation length on survival traits.

In a pre-analysis a fixed effect 'cross-fostered or not' was included. The effect was highly significant, suggesting that cross-fostering in itself has a positive influence on the survival of piglets. It was dropped from the model, because of the non-random nature of crossfostering. The caretaker decides to transfer a specific piglet to a specific sow. The expected vitality of the piglet and the expected mothering ability of the biological mother 
and the new nurse sow influence this decision. Inclusion of this fixed effect will, therefore, bias the analysis.

\section{Genetic parameters for birth weight and farrowing survival}

The analysis of birth weight gave similar and consistent results for both lines. The best model was the direct-maternal model with the higher contribution from the maternal effect. This is in good agreement with the results of the very extensive analysis of birth weight by Roehe (1999), who estimated 0.08 for the direct heritability, 0.22 for the maternal heritability and $-0.22 \pm 0.20$ for the genetic correlation. In the current analysis these values were $0.03(0.06), 0.22(0.18)$ and $0.30 \pm 0.38(-0.22 \pm 0.16)$ for the dam line (and for the sire line). (Table 3). Kerr and Cameron (1995) reported a direct heritability of $0.14 \pm 0.02$ for individual birth weight using Model 1 , while in the present analyses values of 0.43 and 0.33 were found. A possible explanation is the common environment estimate, which was 0.37 for Kerr and Cameron (1995) and 0.09 and 0.13 in the present analyses.

In a strictly formal sense the two lines differed in their best models for farrowing survival, based on the comparison of the log-likelihood's. Table 4 reveals large similarities in variance component estimates. Using Model 1, direct genetic effects of 25.6 and 32.5 were found for the two lines; with Model 2, maternal genetic effects of 18.3 and 17.4. Model 4 directed most of the variance towards the maternal effect; note, however, that the estimates of the genetic covariances differed considerably between the lines. Both estimates did not differ significantly from zero or from one another. In both lines, no significant gain in log-likelihood was found going from Model 2 to Model 4. This resulted in heritabilities of 0.03 for the maternal effect of farrowing survival.

This maternal effect on farrowing survival can be compared with estimates of percent stillborn (\%-stillborn) on a litter level. Most estimates on stillborn, however, are expressed as number (\#) stillborn. Siewerdt and Cardellino (1996) gave heritabilities for both traits: \#-stillborn, 0.016 and \%-stillborn, 0.004. In particular, the latter number is a very low estimate, possibly caused by the use of a sire model and including litter effect. A sire model ignores the genetic contribution of the sow, which will then be largely attributed to the litter effect. Johnson et al. (1999) found a relatively high heritability of 0.17 for \#-stillborn, while their estimates for litter size, \#-born alive and \#-mummified were also high, as was their genetic correlation between litter size and \#-stillborn. 
Hanenberg et al. (2001) estimated 0.020 and 0.048 for \#-stillborn in first and higher parity sows, respectively. In the current analysis phenotypic corrections were made for birth weight, litter size and parity. A heritability of 0.03 is considered low, but a genetic standard deviation of over $4 \%$ farrowing survival (square root of the maternal variance of Model 2, Table 4), compared with an average \%-stillborn of $7 \%$ (Table 1 ) is high.

Exact registration of stillborn is difficult; some piglets are mistakenly considered stillborn since they have breathed but not moved after birth. In field data part of the preweaning mortality before the first check is registered as stillborn. In creating the current data set the exact definitions were used and the calculated genetic parameters apply for this situation. A different definition of stillborn will yield somewhat different results.

\section{Pre-weaning survival and evidence for mothering ability}

Cross-fostering of piglets increased pre-weaning survival probability by some $3.3 \%$ in the dam line, while piglets were $80 \mathrm{~g}$ lighter on average, which is equivalent to $1.4 \%$ survival in that area of the survival/birth weight curve. Survival of cross-fostered piglets on the sire line was $1.6 \%$ lower than with the non-cross-fostered piglets, but their birth weight was $210 \mathrm{~g}$ lower, which is equivalent to $4.4 \%$ survival. Cross-fostering, therefore, improved pre-weaning survival by $4.7 \%$ and $2.8 \%$ respectively and is an indication of phenotypic differences in mothering ability.

Mothering ability enters the equation for pre-weaning survival and can be estimated if cross-fostering is applied. The best model for pre-weaning survival was Model 6, the maternal/nurse sow model. The estimates for the variance components differ widely between the lines, 18.0 and 278.0 for the maternal effects and 19.6 and 196.2 for the nurse sow effects in the dam line and sire line, respectively (Table 5). If total genetic variance is calculated with the formula, $\sigma_{g}^{2}=\sigma_{m}^{2}+\sigma_{f}^{2}+2 * \sigma_{f m}$, the result is 35.0 for the dam line and 39.4 for the sire line. The lines differed in the amount of cross-fostering, which was $17.8 \%$ in the dam line and $6.3 \%$ in the sire line respectively, making it much more difficult to disentangle maternal and nurse sow effects in the sire line. Johnson et al. (1999) used Model 5 to analyze pre-weaning mortality and reported heritabilities of 0.03 for the direct effect and 0.07 for the nurse sow effect. Table 5 shows these estimates to be 0.01 and 0.02 for the dam line and 0.04 and 0.03 for the sire line. Kerr and Cameron (1995) estimated a direct heritability of 0.04 with Model 1 , which is similar to the current estimates of 0.05 for both lines. Rothschild and Bidanel (1998) averaged 16 literature estimates for pre-weaning mortality at the sow level, with the result of a mean heritability 
of 0.05 with the full range of possibilities from 0.00 to 0.97 . This value of 0.05 should be compared with the 0.03 and 0.04 results of Model 2 from Table 5.

\section{Combination of farrowing survival and pre-weaning survival}

Piglet survival was defined as the probability of survival from late gestation to weaning, and,-therefore, combined the traits farrowing survival and pre-weaning survival. Results in Table 6 seem quite erratic. Models without nurse sow effects had a much lower log-likelihood than models including nurse sow effect, while at the same time estimates for nurse sow effect were very high, resulting in estimated heritabilities between 0.15 and 0.36 (Table 6). This is possibly caused by the specific data structure; stillborn piglets had a missing value for the nurse sow, obviously. Especially for Model 3 (which only takes into account the nurse sow effect) these stillborn piglets did not contribute to the genetic variances, but did influence litter effect. The net result was an overestimated nurse sow effect and a lower litter effect than in models without the nurse sow effect. It is unclear why the likelihood of these models is so much higher.

From another perspective, the direct, maternal and direct/maternal models yielded quite consistent results within and between lines. The sum of the variances of the direct effects of farrowing and pre-weaning survival was 66.0 for the dam line and 87.3 for the sire line (Tables 4 and 5), while their estimated variances for piglet survival were respectively 81.0 and 131.3 (Table 6). A similar calculation for the maternal effects gave 46.4 and 56.9 for the sums and 54.0 and 65.6 for the maternal variance for piglet survival.

Van Arendonk et al. (1996) analyzed the same trait with partially the same data set and estimated, in their best model, heritabilities of 0.11 for the direct effect and 0.09 for the maternal effect with a high, very significant, negative genetic correlation. If total genetic variance is calculated with the formula, $\sigma_{\mathrm{g}}^{2}=\sigma_{\mathrm{a}}^{2}+0.5^{*} \sigma_{\mathrm{m}}^{2}+1.5^{*} \sigma_{\mathrm{am}}$, then the Van Arendonk et al. (1996) results yielded 91.5, the Model 4 results from Table 6, 1.5 for the dam line and 35.5, for the sire line. In the Van Arendonk article piglets from several lines and crosses were analyzed simultaneously. The current results were obtained from within-line analyses. Between line variation can explain at least part of the difference.

It is concluded that modeling piglet survival does not give convincing results. For a large part, because of the stillborn-nurse sow problem and possibly because of the low degree of crossfostering and/or because of the different genetic models underlying the component traits. 


\section{Possibility of selection for piglet survival}

On the basis of the results presented, modeling piglet survival as the combination of farrowing and pre-weaning survival is too complicated with the given data structure and method of analysis. Analyses of farrowing and pre-weaning survival gave consistent results within as well as between the two lines. Estimated genetic variance for the direct genetic effects was around 30 for farrowing survival and around 45 for pre-weaning survival (Tables 4 and 5). For maternal effects estimates were around 18 for farrowing survival and around 32 for pre-weaning survival, while the nurse sow contributed some 23 units to pre-weaning survival.

The use of a more sophisticated model, such as Model 6, for pre-weaning survival resulted in a value for total genetic variance of roughly 37 (Table 5). For farrowing survival genetic variance was around 18 (Table 4). On the basis of these values a genetic variance for piglet survival of around 55 seems realistic, which results in a genetic standard deviation of $7.5 \%$ and a heritability of around 0.05 . Under single trait mass selection a genetic gain of $1.6 \%$ survival could be realized per year, if selection intensity and generation interval are assumed to be 1 , a somewhat optimistic assumption.

\section{Conclusions}

Exploitable genetic variance exists for piglet survival and its component traits, heritability is low, but genetic variance is considerable. Modeling total piglet survival simultaneously with direct, maternal, and nurse sow effects was not successful. For farrowing survival, pre-weaning survival and birth weight best fitting models were found, a maternal, a maternal/foster sow and a direct/maternal model, respectively. Variance components estimated in two fully separate data sets for a sire line and a sow line on two different farms showed a high degree of consistency. The phenotypic correlation of birth weight with piglet survival is moderate, but the genetic correlation is almost zero.

\section{Acknowledgements}

The authors want to express their thanks to Rob Bergsma for his endless work in data preparation, to Sheila Roberton for her help with the English language and to all farmers and farm staff for their patient and careful recording of piglet information, even if their data were not used for this specific article (>90\%). 


\section{References}

Bereskin, B., C.E. Shelby, and D.F. Fox. 1973. Some factors affecting pig survival. J. Anim. Sci. 36, 821-827.

Fireman, F.A.T., and F. Siewerdt. 1997. Efeito do peso ao nascer sobre a mortalidade de leit es do nascimento até 21 dias de idade. $R$. Bras. Zootec. 26, 479-484.

Hanenberg, E.H.A.T., E.F. Knol, and J.W.M. Merks. 2001. Estimates of genetic parameters for reproduction traits at different parities in Dutch Landrace pigs. Livest. Prod. Sci. (accepted).

Gilmour, A.R., B.R. Cullis, and S.J. Welham, and R. Thompson. 1999. ASREML. NSW Agriculture, occasional publication.

Johnson, R. K., M.K. Nielsen, and D.S. Casey. 1999. Responses in ovulation rate, embryonal survival, and litter traits to 14 generations of selection to increase litter size. J. Anim. Sci. 77, 541-557.

Kerr, J.C., and N.D. Cameron. 1995. Reproductive performance of pigs selected for components of efficient lean growth. Anim. Sci. 60, 281-290.

Lamberson, W.R., and R.K. Johnson. 1984. Preweaning survival in swine: heritability and maternal effects. J. of Anim. Sci. 59, 346-349.

Leenhouwers, J.I., T. van der Lende, and E.F. Knol. 1998. Analysis of stillbirth in different lines of pig. Livest. Prod. Sci. 57, 243-253.

Roehe, R., 1999. Genetic determination of individual birth weight and its association with sow productivity traits using bayesian analyses. J. Anim. Sci. 77, 330-343.

Roehe, R., and E. Kalm. 2000: Estimation of genetic and environmental risk factors associated with pre-weaning mortality in piglets using generalized linear mixed models. Anim. Sci. 70, 227-240.

Rothschild, M.F., and J.P. Bidanel. 1998. Biology and genetics of reproduction. In: M.F. Rothschild and A. Ruvinsky (ed) Genetics of the pig. p 323. CAB International, Oxon, UK.

Siewerdt, F., and R.A. Cardellino. 1996. Genetic parameters of piglet mortality from birth to 21 days of age in the Landrace breed. Revta Soc. Bras. Zootéc. 25, 902-909.

Van Arendonk, J.A.M., C. van Rosmeulen, L.L.G. Janss, and E.F. Knol. 1996. Estimation of direct and maternal genetic (co)variances for survival within litters of piglets. Livest. Prod. Sci. 46, 163-171. 


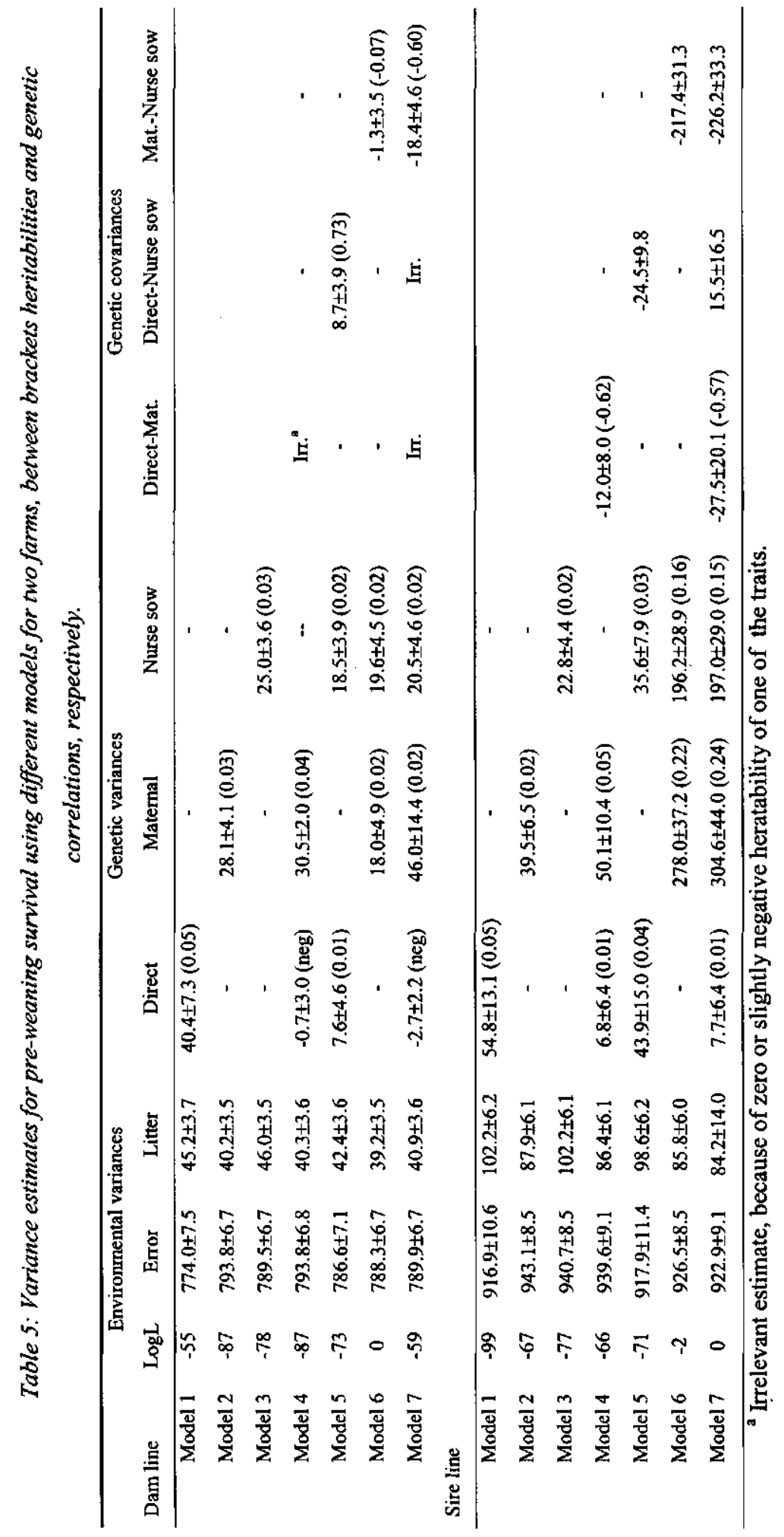




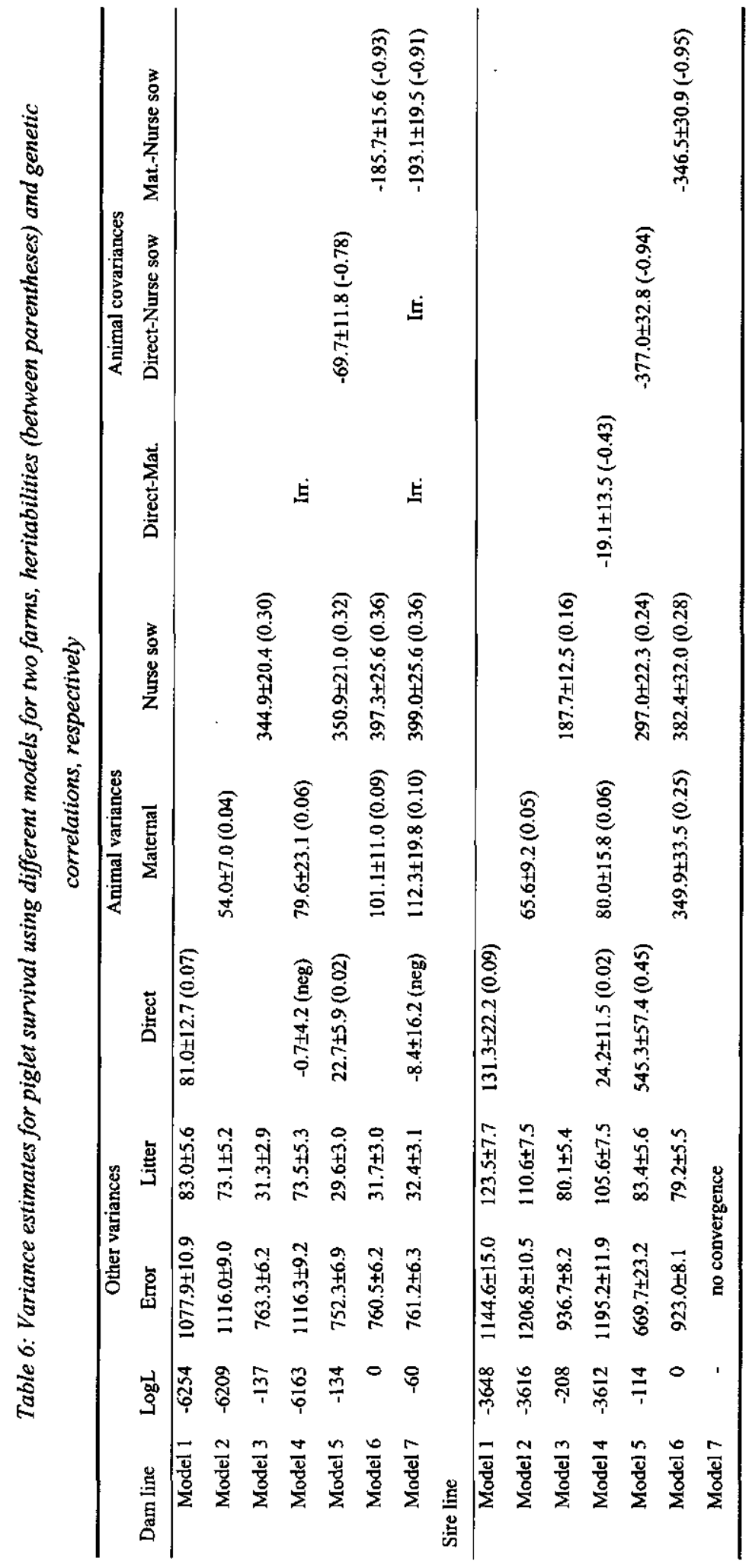




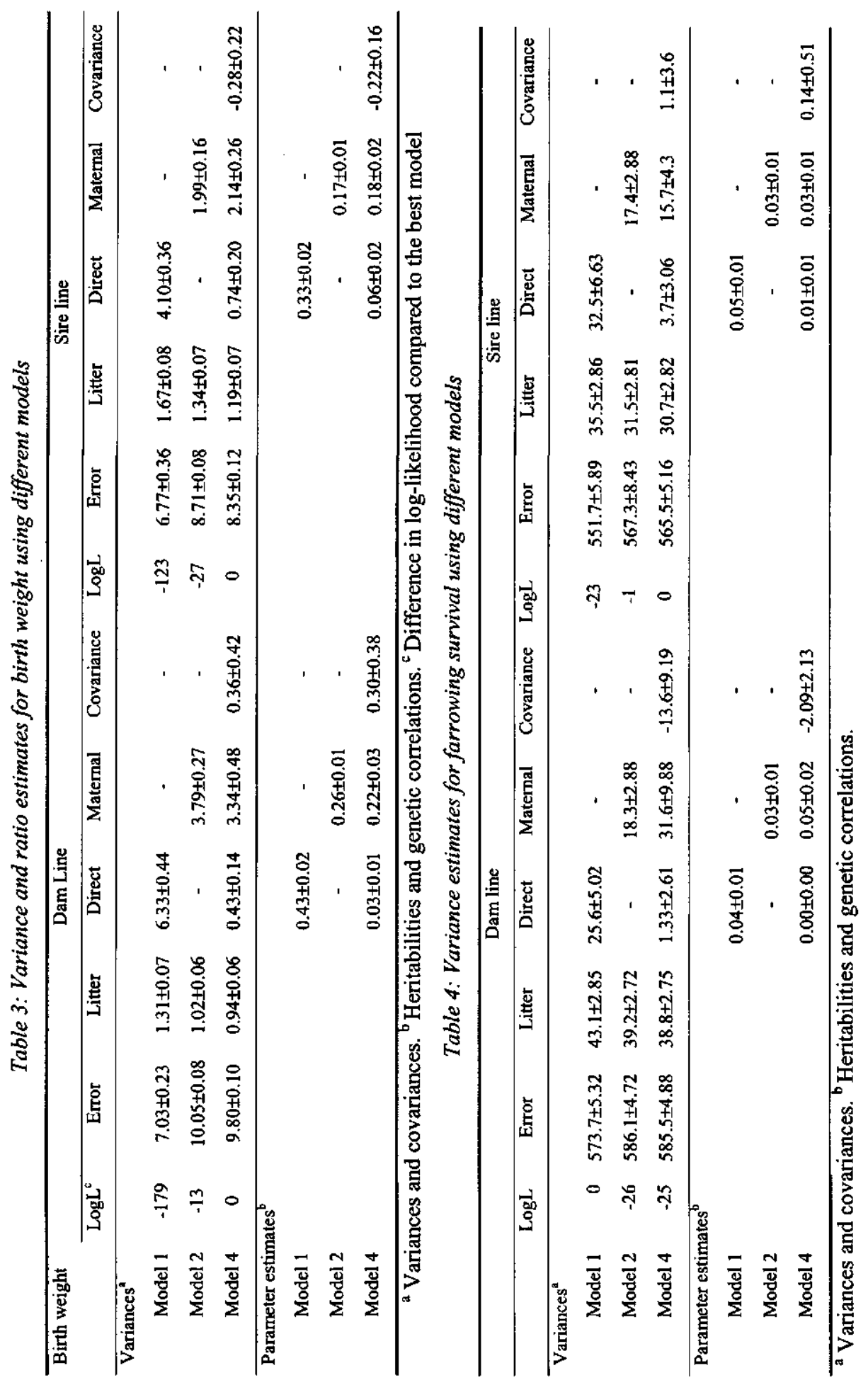


Piglet losses were classified as:

(f) missing - piglets that, by their own action, got out of the farrowing crates or pens and into the gutter system and inadvertently went out with the manure;

McKay (1993) 


\title{
1 Predictive value of breeding values in three strategies to select for improved piglet survival
}

\begin{abstract}
Perinatal mortality in pigs is high. Estimated heritabilities for survival are low. The goal of this study was to investigate the expected effects of selection for increased survival and to compare these results with a selection strategy for increased birth weight. Data of around 60.000 piglets taken from half a year of production on two farms were used to predict breeding values for survival traits and birth weight for future litters of gestating sows. Realized survival and birth weights were analyzed and compared with predicted breeding values. The relationship between predicted and realized values for both survival and birth weight was very good. Regression coefficients of realized survival on predicted survival were close to the expected values of 1.0 for piglet survival and birth weight. Selection for increased birth weight, however, did not result in a correlated response in piglet survival. It was concluded that the best way to genetically increase perinatal survival in pigs is to select for this trait directly. Selection for increased birth weight is not expected to increase perinatal survival.
\end{abstract}

Keywords: Selection, Perinatal Mortality, Piglets, Birth Weight, Variation in Birth Weight

\section{Introduction}

Survival from late gestation to weaning in pigs is low, around $81 \%$, both in the Netherlands and in the USA (Kengetallenspiegel, 1999 and PigCHAMP, 1998). This low

\section{Submitted:}

E.F. Knol, J.I. Leenhouwers and T. van der Lende. Predictive value of breeding values in three strategies to select for improved piglet survival 
survival is harmful to the piglets, harmful to the economy of the farmer and harmful to public acceptance of the industry.

In a previous paper (Knol et al., 2001a), different genetic models describing piglet survival and its components, farrowing and pre-weaning survival, were compared. Estimated heritabilities were significant, but low, which is in agreement with Rothschild and Bidanel (1998), Kerr and Cameron (1995) and Roehe and Kalm (2000). The latter two papers conclude that the heritability is too low to realize substantial genetic gain and both suggest indirect selection for birth weight. Many publications stress the importance of birth weight for piglet survival (e.g. Bereskin, 1973; Fahmy, 1978; Fireman, 1997; Daza 1999), suggesting to the reader that birth weight is more or less equivalent to survival. However, after phenotypic correction for birth weight, there is still considerable genetic variation for piglet survival (Knol, 2001b). A straightforward selection strategy would be to select for the direct component of piglet survival and to ignore maternal and nurse sow effects. An alternative strategy could be to select for the direct component of birth weight as the most important factor for piglet survival. The efficiency of both procedures can be predicted using deterministic simulation. Experimental validation of these predictions is lacking.

The objectives of this study were to use data analysis to:

1. investigate the predictive value of breeding values for piglet survival in future litters,

2. investigate the correlated response in survival traits in future litters to selection for birth weight,

3. check for possible correlated responses of these two selection strategies on other litter traits.

\section{Material and Methods}

\section{General}

Data sets were the same as used by Knol et al. (2001a). Data were collected on two farms, a multiplier with a dam line and a boar nucleus with a sire line, both with on-farm production of replacement gilts. Line and farm are therefore confounded. Reference will be made to line. All piglets, including stillborns, but excluding mummified piglets were 
weighed within 24 hours after birth and mortality was recorded until weaning. Realized piglet survival as a litter trait, a trait of the sow, was calculated by taking the number of surviving piglets as a percentage of the total number of littermates at birth, excluding mummified piglets. Piglet survival, therefore, was as much an indication of uterine quality as an indication of mothering ability. Variation in birth weight was calculated as the within-litter variation. For further details see Knol (2000a). From both data sets observations of the second and third trimester of 1999 were the last two trimesters of the data set. They were set aside and will be referred to as 'test sets'.

\section{Breeding value estimation}

Breeding values for piglet survival were predicted with ASREML of Gilmour et al. (1999) using the following two models (ignoring subscripts):

$$
\begin{aligned}
\mathrm{Y}= & \text { HYS }+ \text { Sex }+ \text { Cross }+ \text { Parity }+\underline{\text { Birth weight }+} \\
& \text { b1*Variation in birth weight }+b 2^{*} \text { Number born total }+ \\
& \text { Litter }+ \text { Piglet }+ \text { Error, } \\
\mathrm{Y}=\quad & \mathrm{HYS}+\text { Sex }+ \text { Cross }+ \text { Parity }+ \\
& \text { b1*Variation in birth weight }+b 2^{*} \text { Number born total }+ \\
& \text { Litter }+ \text { Piglet }+ \text { Error },
\end{aligned}
$$

with Birth weight in classes of 100 grams, Variation in birth weight and Number born total as co-variables and with Litter, Piglet and Error as random effects. Heritability was estimated in a separate data set with both the sire and dam line animals on the same farm and using model 1 . The heritability for piglet survival found in this analysis $(0.073)$ was between the values given by Knol et al (2001a) for the sire and dam line separately. Y was piglet survival from late gestation to weaning. The individual piglet was the unit of observation. Breeding values for birth weight were, for obvious reasons, only estimated with model $1 \mathrm{~b}$. Three selection strategies were evaluated: 1) improvement of survival at a given birth weight (ST1), 2) improvement of survival regardless of the correlated response in birth weight (ST2) and improvement of survival as the correlated response of an increase in birth weight (ST3). 
Analysis

The test set for the dam line consisted of 2700 piglets, and for the sire line of 3833 piglets. Survival traits and birth weight were averaged across each litter. These litter tests set were split into high and low EBV groups, (within line) and uncorrected means were calculated. Subsequently, the relation of EBV with each measured trait was estimated across the whole test set within line, with the GLM procedure of SAS (SAS Institute Inc, 1990), using the models:

$$
\begin{aligned}
& Y=H Y S+\text { Parity }+\quad E B V_{z}+\text { Error } \\
& Y=H Y S+\text { Parity }+b 1 * B W+b 2 * B W^{2}+E B V_{z}+\text { Error }
\end{aligned}
$$

where HYS was the effect of Herd Year Season in trimesters per year (1999.2 and 1999.3), and $E B V_{z}$ was the pedigree index, i.e. the predicted breeding value of the litter for piglet survival (SURV) or birth weight (BW). All traits were analyzed with model 2a and $2 \mathrm{~b} . \mathrm{EBV}_{\mathrm{SURV}}$ was predicted with model $1 \mathrm{a}\left(\mathrm{EBV}_{\mathrm{SURV} \cdot \mathrm{a}}\right)$ and with model $1 \mathrm{~b}$ $\left(E B V_{\text {SURV-b}}\right)$, and $\mathrm{EBV}_{\mathrm{BW}}$ with model $\mathrm{lb}$. This resulted in $3 \mathrm{EBV}$ tables, each with two lines, and each line with two analyses per trait.

\section{Results}

Descriptive statistics of the data sets are given in Table 1. Litter sizes were somewhat higher in the test sets than in the total sets in both lines. Piglet survival was $2.6 \%$ higher in the test set than in the total set in the sire line, but $1.3 \%$ lower in the dam line test set compared with the total set.

Results for ST1 are given in Table 2a. In the dam line, the low EBV group had an average predicted $\mathrm{EBV}_{\mathrm{SURV}-\mathrm{a}}$ of -0.76 , the high group of +4.21 . Expected difference in piglet survival of these groups was then the difference in EBV $_{\text {SURV-a }}: 4.97 \%$. Realized piglet survival in the low EBV group was $78.9 \%$ and in the high group $83.6 \%$ (i.e. a realized difference of $4.7 \%)$. Analysis of piglet survival yielded a significant $(\mathrm{P}=0.009)$ 
positive regression coefficient of 0.92 , i.e. each unit of genetic piglet survival resulted in $0.92 \%$ of realized piglet survival.

Table 1: Descriptive statistics of the total data sets and of the test sets for both lines.

\begin{tabular}{lcccc}
\hline & \multicolumn{2}{c}{ Dam line } & \multicolumn{2}{c}{ Sire line } \\
& Total set & Test set & Total set & Test set \\
\hline No. of observations & 33717 & 2700 & 29200 & 3833 \\
Sex ratio, \% boars & 52 & 53 & 52 & 52 \\
Cross fostering, \% & 18 & 19 & 6 & 7 \\
Piglet survival, \% & 82.2 & 80.9 & 79.2 & 82.4 \\
Farrowing survival, \% & 92.7 & 92.2 & 93.2 & 95.2 \\
Pre-weaning survival, \% & 88.7 & 87.7 & 85.0 & 86.6 \\
Litter size & 12.0 & 12.4 & 10.2 & 10.6 \\
Birth weight, kg (BW) & 1.44 & 1.46 & 1.42 & 1.47 \\
Variation in BW, g & 309 & 296 & 277 & 267 \\
\hline
\end{tabular}

Birth weight in the high $\mathrm{EBV}_{\mathrm{SURV}}$ group was somewhat, but not significantly, lower than in the low group (1.46 vs. 1.48). Corrected for this lower birth weight, piglet survival (model 2b) in the low group was significantly higher $(\mathrm{P}=0.004)$ and the regression coefficient was 0.97 realized survival per unit of predicted survival. As EBV $_{\text {SURV }}$ was predicted with a model including a phenotypic correction for birth weight (model 1a), the proper verification of realized survival should therefore include a correction for birth weight too (model $2 b$ ).

Piglet survival is the product of farrowing survival and pre-weaning survival. EBV $_{\text {SURV-a }}$ seems to have a positive relationship with both component traits. Farrowing survival in the high EBV group was $1.7 \%$ higher than in the low EBV group, while preweaning survival was $2.7 \%$ higher. The regression coefficient of farrowing survival on EBV $_{\text {SURV-a }}$ (model $2 \mathrm{~b}$ ) was $0.42(\mathrm{P}=0.11)$, and that of pre-weaning survival on $\mathrm{EBV}_{\text {SURV-a }}$ was $0.65(\mathrm{P}=0.01)$. Litter size of the high EBV group was similar to the litter size of the low EBV group, but both litter weight and variation in birth weight were significantly lower in the high group. 
Table 2a: Uncorrected means for two lines, where litters were assigned to a low EBV $V_{S U R \text {-a }}$ or a high EBV $V_{S U R \text {-a }}$ group (discrete approach). Significance levels and partial regression coefficients (b) were based on GLM analyses (continuous approach), without correction for birth weight (model $2 a$ ) and with correction (model $2 b$ ).

\begin{tabular}{lcccccccccccc}
\hline & \multicolumn{1}{c}{ Dam line } & \multicolumn{1}{c}{ Sire line } \\
& EBV & EBV & b & Sign. & b & Sign. & EBV & EBV & b & Sign. & b & Sign. \\
& low & high & $(2 \mathrm{a})$ & & $(2 \mathrm{~b})$ & & low & high & $(2 \mathrm{a})$ & & $(2 \mathrm{~b})$ & \\
\hline \# of litters & 107 & 108 & & & & & 179 & 182 & & & & \\
Parity & 3.94 & 4.37 & & & & & 2.87 & 2.66 & & & & \\
EBV & -0.76 & 4.21 & & & & & 0.55 & 4.75 & & & & \\
Piglet surv. \% & 78.9 & 83.6 & 0.92 & $0.01^{1}$ & 0.97 & 0.004 & 81.0 & 83.8 & 0.92 & 0.02 & 1.29 & 0.001 \\
Farr. Surv. \% & 90.7 & 93.4 & 0.39 & 0.14 & 0.42 & 0.11 & 93.8 & 95.9 & 0.37 & 0.08 & 0.36 & 0.08 \\
PW surv. \% & 86.7 & 89.4 & 0.61 & 0.02 & 0.65 & 0.01 & 86.0 & 87.4 & 0.65 & 0.07 & 1.07 & 0.002 \\
& & & & & & & & & & & & \\
Total \# born & 12.53 & 12.31 & -0.08 & 0.15 & & & 10.61 & 10.62 & 0.06 & 0.34 & & \\
Sex ratio & 51.8 & 53.0 & & 0.99 & & & 51.2 & 51.9 & & 0.80 & & \\
Litter weight ${ }^{2}$ & 18.1 & 17.6 & -0.18 & 0.02 & & & 15.5 & 14.9 & -0.06 & 0.36 & & \\
Av. BW, g & 1480 & 1460 & -2 & 0.64 & & & 1500 & 1430 & -17 & 0.001 & & \\
Var. BW, g & 302 & 295 & -5 & 0.01 & & & 291 & 259 & -7 & 0.001 & & \\
\#weaned & 9.89 & 10.19 & 0.02 & 0.69 & & & 8.59 & 8.91 & 0.13 & 0.03 & & \\
\hline
\end{tabular}

'Significance expressed as $\mathrm{P}$ values, ${ }^{2}$ Litter weight in $\mathrm{kg}$.

In the sire line the results were similar (Table $2 a)$. Piglet survival increased $(\mathrm{p}=0.02)$ with increasing EBV $_{\text {SURV-a }}$ (model $2 \mathrm{a}$ ), as did both farrowing- and pre-weaning survival. Birth weight decreased significantly $(\mathrm{P}=0.001)$, as did variation in birth weight $(\mathrm{P}=0.001)$. Significance of the relationship between predicted and realized survival increased substantially $(\mathrm{P}=0.001$ ), when correction for birth weight was applied (model 2b).

Table $2 \mathrm{~b}$ gives results for the situation in which no correction for birth weight was applied in the EBV estimation (ST2). Model 2a results yielded regression coefficients between realized and predicted survival of 0.78 for the dam line and 0.90 for the sire line, somewhat lower than those given in Table 2a. 
Table 2b: Responses and correlated responses of a grouping on predicted $E B V_{S U R V}$, where $E B V_{S U R V}$ was estimated with a model excluding birth weight. Presentation of results identical to Table $2 a$.

\begin{tabular}{lcccccccccccc}
\hline & \multicolumn{1}{c}{ Dam line } & \multicolumn{1}{c}{ Sire line } \\
& EBV & EBV & b & Sign. & b & Sign & EBV & EBV & b & Sign. & b & Sign. \\
& low & high & $(2 \mathrm{a})$ & & $(2 \mathrm{~b})$ & & Low & high & $(2 \mathrm{a})$ & & $(2 \mathrm{~b})$ & \\
\hline \# of litters & 108 & 107 & & & & & 177 & 184 & & & & \\
Parity & 4.02 & 4.30 & & & & & 2.79 & 2.74 & & & & \\
EBV & -0.74 & 5.02 & & & & & 0.33 & 4.41 & & & & \\
Piglet surv.\% & 78.0 & 84.5 & 0.78 & 0.01 & 0.66 & 0.03 & 80.4 & 84.3 & 0.90 & 0.02 & 0.95 & 0.01 \\
Farr.surv. \% & 90.3 & 93.8 & 0.46 & 0.05 & 0.40 & 0.09 & 94.1 & 95.6 & 0.26 & 0.20 & 0.24 & 0.23 \\
PW surv. \% & 86.1 & 90.1 & 0.40 & 0.07 & 0.34 & 0.11 & 85.2 & 88.2 & 0.72 & 0.05 & 0.79 & 0.02 \\
& & & & & & & & & & & & \\
Total \# born & 12.56 & 12.29 & -0.08 & 0.17 & & & 10.77 & 10.47 & 0.05 & 0.38 & & \\
Sex ratio & 52.3 & 52.5 & & 0.91 & & & 51.4 & 51.8 & & 0.64 & & \\
Litter weight & 17.8 & 17.9 & -0.04 & 0.54 & & & 15.4 & 15.0 & 0.03 & 0.65 & & \\
Av. BW, g & 1450 & 1480 & 6 & 0.22 & & & 1470 & 1470 & -5 & 0.38 & & \\
Var. BW, g & 301 & 296 & -3 & 0.08 & & & 285 & 265 & -6 & 0.003 & & \\
\#weaned & 9.79 & 10.29 & 0.03 & 0.61 & & & 8.67 & 8.83 & 0.11 & 0.06 & & \\
\hline
\end{tabular}

Differences between high and low EBV groups in piglet survival and in farrowing and pre-weaning survival were very similar to those shown in Table $2 \mathrm{a}$. In terms of correlated responses, the decrease in litter weight, as seen in the dam line in Table 2a, disappeared, as did the decrease in birth weight in the sire line. The reduction in variation in birth weight remained, albeit somewhat less pronounced than in Table $2 a$.

Selection for birth weight (ST3) increased birth weight significantly (Table 2c), but did not significantly increase piglet survival on either farm. After correction for the increase in birth weight, piglets in the sire line had a lower survival rate $(\mathrm{P}=0.002)$. An increase in $\mathrm{EBV}_{\mathrm{BW}}$ decreased the number of piglets weaned per litter significantly $(P=0.007)$ in the sire line due mainly to a lower litter size $(P=0.04)$. Variation in birth weight increased significantly with increasing $\mathrm{EBV}_{\mathrm{Bw}}$, in both lines. 
Table 2c: Responses and correlated responses to a selection step on birth weight, where $E B V_{B W}$ was estimated with a model with direct effect of birth weight in the model. Presentation of results identical to Table $2 a$.

\begin{tabular}{lccccccccccccc}
\hline & \multicolumn{1}{c}{ Dam line } & \multicolumn{8}{c}{ Sire line } \\
& EBV & EBV & b (2a) & Sign. & b (2b) & Sign. & EBV & EBV & b & Sign. & b (2b) & Sign. \\
& low & high & & & & & low & high & $(2 \mathrm{a})$ & & & \\
\# of litters & 108 & 107 & & & & & 182 & 179 & & & & \\
Parity & 4.24 & 4.07 & & & & & 2.82 & 2.70 & & & & \\
EBV & -0.53 & 0.88 & & & & & -1.23 & -0.24 & & & & \\
Piglet surv \% & 80.2 & 82.3 & 0.22 & 0.86 & -0.75 & 0.53 & 83.9 & 80.9 & -2.0 & 0.18 & -4.53 & 0.01 \\
Farr.surv. \% & 90.8 & 93.3 & 1.31 & 0.17 & 0.90 & 0.34 & 95.6 & 94.2 & -1.1 & 0.19 & -1.11 & 0.19 \\
PW surv. \% & 88.1 & 88.1 & -0.98 & 0.27 & -1.65 & 0.06 & 87.8 & 85.6 & -1.5 & 0.29 & -4.29 & 0.01 \\
& & & & & & & & & & & & \\
Total \# born & 12.62 & 12.22 & -0.09 & 0.66 & & & 11.0 & 10.24 & -0.48 & 0.04 & & \\
Sex ratio & 51.0 & 53.8 & & 0.33 & & & 51.1 & 52.1 & -0.09 & 0.94 & & \\
Litter weight & 17.5 & 18.2 & 0.55 & 0.04 & & & 15.1 & 15.3 & 0.21 & 0.44 & & \\
Av. BW, g & 1410 & 1520 & 52 & 0.01 & & & 1400 & 1540 & 106 & 0.01 & & \\
Var. BW, g & 293 & 304 & 7 & 0.30 & & & 272 & 278 & 15 & 0.06 & & \\
\#weaned & 10.06 & 10.01 & -0.02 & 0.91 & & & 9.20 & 8.29 & -0.62 & 0.01 & & \\
\hline
\end{tabular}

Since variation in birth weight appears to be related to survival, the distribution of survival across different birth weight categories was calculated. In Table 3 numbers of piglets and piglet survival rates are given for the different birth weight classes in both lines split into low and high $\mathrm{EBV}_{\mathrm{SURV}}$ groups. In the dam line and especially in the sire line is a tendency for fewer very heavy piglets in the high EBV group can be observed. In the dam line 20 piglets in the low EBV group had a weight higher than $2.3 \mathrm{~kg}$, in the high group only 7 , these figures were 17 and 6 , respectively, in the sire line. Survival rates seemed to increase with high $\mathrm{EBV}_{\text {SURV }}$ in most of the weight classes, notably in weight classes below $1.0 \mathrm{~kg}$. 
Table 3: Uncorrected piglet survival averages of low and high EBV piglets for different birth weight classes within farm.

\begin{tabular}{|c|c|c|c|c|c|c|c|c|}
\hline & \multicolumn{4}{|c|}{ Dam line } & \multicolumn{4}{|c|}{ Sire line } \\
\hline $\begin{array}{l}\text { Birth } \\
\text { weight }\end{array}$ & $\begin{array}{l}\text { No. } \\
\text { piglets } \\
\text { low }\end{array}$ & $\begin{array}{c}\text { No. } \\
\text { piglets } \\
\text { high }\end{array}$ & $\begin{array}{c}\text { Survival } \\
\text { EBV } \\
\text { low }\end{array}$ & $\begin{array}{c}\text { Survival } \\
\text { EBV } \\
\text { high }\end{array}$ & $\begin{array}{l}\text { No. } \\
\text { piglets } \\
\text { low }\end{array}$ & $\begin{array}{c}\text { No. } \\
\text { Piglets } \\
\text { High } \\
\end{array}$ & $\begin{array}{c}\text { Survival } \\
\text { EBV } \\
\text { Low }\end{array}$ & $\begin{array}{c}\text { Survival } \\
\text { EBV } \\
\text { High }\end{array}$ \\
\hline 0.3 & & 2 & & 0.0 & 5 & 1 & 0,0 & 0,0 \\
\hline 0.4 & 5 & 2 & 0,0 & 0,0 & 5 & 2 & 0,0 & 0,0 \\
\hline 0.5 & 9 & 6 & 11,1 & 0,0 & 11 & 16 & 18,2 & 18,8 \\
\hline 0.6 & 19 & 17 & 5,3 & 58,8 & 25 & 30 & 40,0 & 13,3 \\
\hline 0.7 & 22 & 25 & 22,7 & 48,0 & 43 & 30 & 32,6 & 33,3 \\
\hline 0.8 & 35 & 34 & 42,9 & 61,8 & 46 & 51 & 47,8 & 60,8 \\
\hline 0.9 & 43 & 61 & 76,7 & 70,5 & 66 & 69 & 56,1 & 65,2 \\
\hline 1.0 & 78 & 67 & 70,5 & 68,7 & 99 & 99 & 63,6 & 76,8 \\
\hline 1.1 & 94 & 92 & 69,2 & 75,0 & 103 & 112 & 77,7 & 83,0 \\
\hline 1.2 & 122 & 102 & 73,8 & 76,5 & 151 & 185 & 67,6 & 81,1 \\
\hline 1.3 & 108 & 131 & 81,5 & 84,7 & 164 & 217 & 79,9 & 84,3 \\
\hline 1.4 & 144 & 150 & 83,3 & 87,3 & 171 & 226 & 87,7 & 87,6 \\
\hline 1.5 & 134 & 147 & 88,1 & 90,5 & 210 & 222 & 86,2 & 92,3 \\
\hline 1.6 & 140 & 114 & 83,6 & 80.7 & 174 & 215 & 91,4 & 89,3 \\
\hline 1.7 & 116 & 122 & 86,2 & 93,4 & 174 & 171 & 93,1 & 93,0 \\
\hline 1.8 & 96 & 112 & 94,8 & 90,2 & 157 & 125 & 93,0 & 94,4 \\
\hline 1.9 & 65 & 48 & 90,8 & 93,8 & 115 & 76 & 91,3 & 90,8 \\
\hline 2.0 & 41 & 49 & 92,7 & 95,9 & 71 & 37 & 95,8 & 100,0 \\
\hline 2.1 & 30 & 37 & 100,0 & 91,9 & 49 & 27 & 98,0 & 96,3 \\
\hline 2.2 & 25 & 11 & 88,0 & 90,9 & 27 & 12 & 96,3 & 100,0 \\
\hline 2.3 & 12 & 6 & 83,3 & 100,0 & 17 & 4 & 94,1 & 100,0 \\
\hline 2.4 & 14 & 4 & 85,7 & 100,0 & 6 & 5 & 83,3 & 100,0 \\
\hline 2.5 & 3 & 1 & 100,0 & 100,0 & 3 & & 100,0 & \\
\hline 2.6 & 1 & 1 & 100,0 & 100,0 & 4 & 1 & 100,0 & 100,0 \\
\hline 2.7 & & 1 & & 0,0 & 2 & & 100,0 & \\
\hline 2.8 & & & & & 1 & & 100,0 & \\
\hline 2.9 & 1 & & 100,0 & & 1 & & 100,0 & \\
\hline 3.0 & & & & & & & & \\
\hline 3.1 & 1 & & 0,0 & & & & & \\
\hline All & 1358 & 1342 & 79,2 & 82,6 & 1900 & 1933 & 81,0 & 83,9 \\
\hline
\end{tabular}

\section{Discussion}

Will selection for piglet survival increase survival?

In both ST1 and ST2 and on both farms piglet survival increased with increasing EBV SURV. The best model for evaluating ST1 was model $2 \mathrm{~b}$, the regression value for the 
dam line in this model was 0.97 and for the sire line 1.29 , with an expected value in each case of 1.0. For ST2 model 2a was best, and the regression values were 0.77 and 0.90 , for dam and sire lines, respectively. In all situations a selection step on the basis of predicted pedigree index for piglet survival yielded a clear increase in survival with minor deviations from the expected value.

The net result in terms of number weaned per litter was somewhat disappointing in the dam line, 0.03 piglets weaned per litter, whereas 0.12 were expected $(1 \%$ increase in survival multiplied by the average litter size). Litter size decreased, but not significantly, with increasing EBV for piglet survival. In the sire line the increase in number weaned was 0.13 , a little above the expected value. Litter weight and average birth weight had a tendency to decrease. Variation in birth weight decreased significantly. Selection on piglet survival is, therefore, possible without negative correlated responses on litter size and without an increase in individual birth weight. These results are not surprising, since they are in agreement with the genetic correlation matrix estimated using similar material (Knol et al. 2001a). The effect of selection on survival can have substantial practical implications. A $50 \%-50 \%$ subdivision of the test sets into low and high EBV groups in the ST2 situation resulted in a decrease in total mortality from $21.6 \%$ to $15.4 \%$ (stillborn from 9.3 to $4.9 \%$ and pre-weaning mortality from 13.9 to $10.1 \%$ ) in the dam line; an interesting economic result.

\section{Does selection for birth weight increase piglet survival?}

The results from ST3, selection for increased birth weight, showed an increase in birth weight, as expected. Birth weight was analyzed in units of $100 \mathrm{~g}$. Regression of birth weight on $\mathrm{EBV}_{\mathrm{BW}}$ was $56 \mathrm{~g}$ for the dam line and $106 \mathrm{~g}$ for the sire line. Correlated responses for survival traits were non-significant. However, in the sire line piglet survival decreased with increasing EBV for birth weight, while birth weight itself increased, i.e. piglets became heavier, but their survival decreased. Corrected for this increase in birth weight, the decrease in survival was significant.

Correlated responses in total number born and numbers weaned per litter were negative. The genetic correlation between average birth weight and litter size is negative (e.g. Roehe, 1999). These results suggest that selection for birth weight will decrease 
intrinsic piglet survival. At best it will maintain phenotypic piglet survival at its current level through an increase in birth weight. A negative response in litter size is expected, according to the current results and the negative correlation between litter size and average birth weight. Number of piglets weaned per litter is, therefore, expected to be negatively influenced by selection for increased birth weight.

Is weighing of piglets necessary for a good survival selection?

The difference between ST1 and ST2 was the individual weighing of piglets. In ST1 birth weight information was used, in ST2 it was not. The significance levels of improvements in survival traits, corrected or uncorrected for birth weight did not differ, and regression coefficients were only marginally lower for ST2. After correction for birth weight, significance levels of ST1 increased somewhat more than significance levels of ST2. Selection on piglet survival following ST2 appears to be only marginally inferior to ST1.

\section{Use of the data analysis technique}

Current analyses started as a demonstration of the possibilities of selection for increased survival. Take a group of pregnant sows with known breeding values for survival, divide them into a high and a low group on the basis of EBV of the litter and observe the performance of the litters after they are born. An analysis like this can be done retrospectively. EBV's are a prediction of future performance in the same units of measurement. Calculation of the regression coefficient with an appropriate model will therefore give a clear indication of the validity of the model and model assumptions used for the EBV estimation. The difference between the high and low $50 \%$ of a normal distribution is 1.35 std. The standard deviation of the distribution in EBV depends on the genetic standard deviation and the accuracy of the prediction. In the current data sets these values were $8 \%$ and 0.4 , respectively. The expected difference between the high and low groups was therefore $8 * 0.4 * 1.35=4.32 \%$ EBV. The realized EBV difference for the dam line was 4.97 and for the sire line $4.2 \%$, a consistent result. If in commercial pig selection programmes selection intensity is around 1.0 std and the generation interval is 1.5 years, then the $50 \%-50 \%$ split approach will give an indication of the effect of two 
years of single trait selection. Conversely, the current finding of a more than $4 \%$ difference in survival within a 50-50 split would lead to a potential increase in survival of $2 \%$ per year, again assuming single trait selection.

A second interesting aspect of this approach is the possibility of investigating correlated responses. If the regression of the realized performance on the predicted performance is not significantly different from 1.0, then the genetic make-up of the animals is representative of the selection direction and other traits can be measured on the animals. This approach is expected to be valuable for any trait in any data set used for breeding value estimation.

\section{Conclusions}

Selection on the direct effect of piglet survival, with or without correction for birth weight, will be successful. It will reduce both percentage stillborn and percentage preweaning mortality. Correlated effects will be a reduction in variation in birth weight and possibly a reduction in birth weight itself. Selection for increased birth weight is expected to decrease, instead of increase, the number of weaned piglets per litter somewhat.

\section{Acknowledgements}

The authors thankfully acknowledge the help of Rob Bergsma in the preparation of the data sets and of Johan van Arendonk for his friendly and helpful comments on the manuscript. This research was financially supported by The Netherlands Technology Foundation (STW).

\section{References}

Bedrijfsvergelijking SIVA software BV, 1999. Kengetallenspiegel. Available at: http://www.siva.nl/nl/result/rzlan99.htm. Accessed at: July 3, 2000.

Bereskin, B., C.E. Shelby, D.F. Fox. 1973. Some factors affecting pig survival. J. Anim. Sci. 36, 821-827. 
Daza, A., J.N.B. Evangelista, M.G. Gutierrez-Barquin. 1999. The effect of maternal and litter factors on piglet mortality rate. Ann. Zootechn. 48, 317-325.

Fahmy, M. H., W.B. Holtmann, T.M. MacIntyre, and J.E. Moxley. 1978. Evaluation of piglet mortality in 28 two-breed crosses among eight breeds of pigs. Anim. Prod. 26, 277-285.

Fireman, F.A.T., F. Siewerdt. 1997. Efeito do peso ao nascer sobre a mortalidade de leit es do nascimento até 21 dias de idade. R. Bras. Zootec. 26, 479-484.

Kerr, J.C. and N.D. Cameron. 1995. Reproductive performance of pigs selected for components of efficient lean growth. Anim. Sci. 60, 281-290.

Gilmour A. R., B.R. Cullis, S.J. Welham, and R. Thompson. 1999. ASREML. NSW Agriculture, occasional publication.

Knol, E.F., B.J. Ducro, J.A.M. van Arendonk, and T. van der Lende. 2001 a. Direct, maternal and nurse sow genetic effects on farrowing-, pre-weaning- and total piglet survival (submitted).

Knol, E.F. 2001b. Genetic Parameters of Litter Mortality in Pigs (submitted).

PigCHAMP database, 1998. Swine data management's Pigchamp record service.

Available at: http://www.netins.net/showcase/swinedata. Accessed July 3, 2000.

Roehe, R., 1999. Genetic determination of individual birth weight and its association with sow productivity traits using bayesian analyses. J. Anim. Sci., 77,330-343.

Roehe, R., and E. Kalm. 2000. Estimation of genetic and environmental risk factors associated with pre-weaning mortality in piglets using generalized linear mixed models. Anim. Sc. 70, 227-240.

Rothschild, M.F., J.P. Biđanel. 1998. Biology and genetics of reproduction. In: M.F. Rothschild and A. Ruvinsky (ed). Genetics of the pig. p 323. CAB International, Oxon, UK.

SAS Institute Inc. 1990. SAS Procedures Guide, Version $6\left(3^{\text {td }}\right.$ ed.). SAS Institute Inc. Cary, NC. 
Piglet losses were classified as:

(d) exposure - piglets that died due to excessive chilling by having crawled into the gutter system;

McKay (1993) 


\title{
Genetic correlations between piglet survival, birth weight and performance traits
}

\begin{abstract}
The genetic relationship between piglet survival and birth weight on one side and performance traits on the other were studied. Measurements were taken on animals in a commercial sire line. For birth weight and survival traits (farrowing-, pre-weaning- and total-) 29,200 observations were available. Performance traits were measured in two test periods, one beginning at $29 \pm 4 \mathrm{~kg}$ and lasting 56 days (Phase1, 2019 observations) and one beginning at the end of Phasel and lasting another 56 days (Phase2). Daily gain and backfat thickness were available for both Phases and feed intake only for Phase2 (1622 observations). Protein and lipid depositions were estimated for both Phases and residual feed intake for Phase2. For birth weight a model with a direct and a maternal animal factor was used; this resulted in heritabilities of 0.05 and 0.20 , respectively. The maternal component of birth weight had positive genetic correlations with lifetime daily gain (0.24 \pm 0.12$)$, estimated protein deposition during Phase2 (0.46 0.18$)$ and a negative correlation with Phase2 backfat (-0.25 \pm 0.11$)$.

For pre-weaning survival a model with a direct (piglet) and a nurse sow animal effect was fitted. Estimated heritabilities were 0.02 and 0.03 respectively. The direct effect of pre-weaning survival had a positive genetic correlation with average daily feed intake

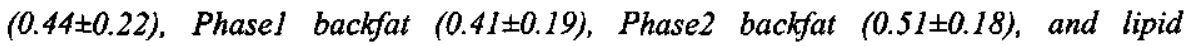
deposition during Phase $2(0.44 \pm 0.19)$, and a negative correlation with estimated residual feed intake (-0.64 \pm 0.28$)$. The nurse sow effect of pre-weaning survival had a negative genetic correlation with Phase2-gain (-0.41 \pm 0.21$)$ and in particular with estimated protein deposition during Phase $2(-0.63 \pm 0.24)$. The study indicated that selection against backfat will increase birth weight and decrease piglet survival, while selection for increased pre-weaning survival will increase gain, feed intake and backfat.
\end{abstract}

Keywords: Piglet Survival, Genetic Parameters, Performance Traits, Birth Weight.

$\overline{\text { Submitted: }}$

Knol, E.F., R. Bergsma, J.A.M. van Arendonk, and T. van der Lende. Genetic correlations between piglet survival, birth weight and performance traits. 


\section{Introduction}

Peri- and pre-weaning mortality in pigs is high. In the USA in 1998, mortality, including stillbirths and pre-weaning deaths, was $19.4 \%$ (1998 PigCHAMP database). In the Netherlands this figure was $19.3 \%$ in 1999 (Bedrijfsvergelijking SIVA software BV.) Mortality, and therefore its complement, survival, shows genetic variation. Rothschild and Bidanel (1998) reported, on the basis of 16 literature estimates, an average heritability of 0.05 for pre-weaning survival. In a previous analysis we found clear indications for the existence of genetic variance in farrowing and pre-weaning survival in pigs ( $\mathrm{Knol}$ et al., 2001a/b). These estimates show that selection for piglet survival is possible.

Mersmann et al (1984) reported lower birth weights and higher survival rates in a genetically obese line of pig in comparison to a genetically lean line. Selection for lean tissue growth rate might result in heavier, but less mature piglets at birth, and thus also affect survival rates (Herpin et al., 1993). Furthermore, selection for reduced backfat thickness and increased growth rate might influence early postnatal capacity for thermoregulation and thus pre-weaning mortality. Herpin and Hulin (2000) quantified thermoregulation in relation to birth weight in Meishan and Pietrain-Large White piglets and found that thermo-regulation in Meishan piglets was much better. These factors imply that commonly practiced selection in favor of daily gain and against backfat traits may be harmful for survival of piglets, and that selection for increased survival might harm finishing performance. Knowledge on the magnitude of phenotypic and genetic correlations between the two within breeds is limited.

This paper reports on the genetic and some phenotypic relationships between piglet survival and birth weight on one side and a number of performance traits on the other. The genotypes of the piglet (direct effect), the sow (maternal effect) and of the sow nursing the piglets (nurse sow effect) are considered for survival traits and, where appropriate, for birth weight. For performance traits the animal effect is the genotype of the tested animal. 


\section{Material and methods}

\section{Material}

The animals used in the analysis were of a commercial sire line of breeding company TOPIGS (Vught, the Netherlands). Survival data from this line were analyzed previously and reported by Knol (2001b). The data set consisted of 29,200 piglets, including stillborn, which were weighed within 24 hours after farrowing. Cross-fostering, date and reason of mortality were recorded. Survival was divided into three traits: farrowing survival, pre-weaning survival and piglet survival, the last trait defined as survival of both the farrowing and the lactation phase. The one third of male piglets with the highestranking pedigree index were transferred from the farm of birth to a testing station with a maximum of 4 boars per litter at an average weight of around $15 \mathrm{~kg}$. The pedigree index used for ranking was:

0.24 * EBV_testgain $-4.6 *$ EBV_backfat $-0.06 *$ EBV_feed intake $+1.3^{*}$ EBV_survival.

At the testing station piglets were mixed with male piglets from two other farms and given an adaptation period until an average weight of $29 \mathrm{~kg}$. At this weight the first 8 week phase of the test started (Phasel), followed by the second 8-week phase of the test (Phase2). Feeding was ad libitum using a mixture of two commercially available feeds, with a high (feed 1) and a low (feed 2) protein content, respectively. Feed 1 contained $208 \mathrm{~g}$ crude protein, $12.7 \mathrm{~g}$ lysine, and 13.5 MJ DE per kg, feed $2146 \mathrm{~g}, 8.5 \mathrm{~g}$ and 13.5 MJ DE, respectively. The feeding regime started with $100 \%$ feed 1 in week 1 , and subsequently the percentage of feed 1 decreased by $7.5 \%$ per week. The ration fed was constant over each week.

Feed intake was recorded daily on an individual pig basis using IVOG $^{\circledR}$ feeding stations during Phase2. Pigs were housed in pens with $75 \%$-slatted floors with 12 animals per pen during Phase1 and 9 animals per per during Phase2. Selection between Phasel and Phase2 was within pen in order not to mix groups, and was based on conformation and weight. Backfat thickness (backfat) was measured at 6 points with an ultrasonic device at the end of Phase1 and Phase 2 comparable to P2 measurement.

Survival data were collected continuously from the third quarter of 1994 until the third quarter of 1999. Test records on performance traits were collected on animals born in this 
period with the exception, due to an outbreak of swine fever in the Netherlands, of piglets born in 1997 and the first 3 months of 1998.

\section{Traits}

The traits available for analysis were:

- gain from birth until start of the test (early gain),

- gain from the start of the test until the end of Phase1 (Phase1-gain),

- gain from the end of Phasel until the end of Phase2 (Phase2-gain) and

- gain from the beginning of Phase1 until the end of Phase2 (test-gain).

- Also available were backfat at the end of Phasel (Phasel-backfat),

- backfat at the end of Phase2 (Phase2-backfat) and

- feed intake during Phase2 (Feed Intake).

From these traits new traits were derived, analysis of which might result in a better understanding of some of the underlying mechanisms of survival. Daily lipid deposition was calculated as the difference between lipid masses at beginning and end of the test divided by length of test period. Lipid mass at the beginning of Phasel was estimated as $10 \%$ of the empty body, assuming $5 \%$ intestinal fill. Lipid mass at the end of Phase 1 and Phase 2 were estimated using the backfat measurements. Protein depositions were calculated by subtracting estimated lipid and ash weights from empty body weights to obtain estimated protein+water weight. The formulae applied were based on the experimental work of de Greef et al. (1994), who used the same line of pigs. Residual feed intake was estimated according to the procedure of De Haer et al. (1993). Details of the estimation of lipid deposition, protein deposition and residual feed intake are given in Appendix 1.

\section{Statistical analysis}

Firstly performance traits were analyzed as single traits with piglet as the random animal factor. Subsequently, bi-variate analyses were performed with piglet survival and with birth weight, again with piglet as the only random animal effect. Finally, piglet survival was replaced with pre-weaning survival, and nurse sow effect was added as a random animal factor in the pre-weaning analysis, following the conclusions of Knol et al. (2001b). A maternal effect was also added as a random animal factor in the birth weight analysis, following Roehe (1999). 
In addition to the animal factors the models for survival traits $\left(\mathrm{Y}_{\mathrm{s}}\right)$ included: the fixed effects HYS (quarter within year within herd), sex, birth weight in units of 100 gram (BW), the covariate litter size (TNB) and the random factor common environment (as litter of birth of the piglet) [1]. Models for birth weight were equal to the models for survival traits except for the obvious exclusion of BW from the model [2]. Models for performance traits $\left(\mathrm{Y}_{\mathrm{f}}\right)$ included the fixed effect HYS (month within year), the random factor common environment (as litter of birth of the piglet) and, for backfat, the covariable weight at the moment of measurement [3]. In formulae, excluding subscripts:

$$
\begin{array}{lll}
\mathrm{Y}_{\mathrm{s}}=\mu+\mathrm{HYS}+\mathrm{Sex}+\mathrm{BW}+\mathrm{b} 1^{*} \mathrm{TNB}+\text { Common }+ \text { Animal }+(\text { Nurse sow })+\text { error [1] } \\
\mathrm{Y}_{\mathrm{bw}}=\mu+\mathrm{HYS}+\mathrm{Sex}+\quad+\mathrm{b} 1^{*} \text { TNB }+ \text { Common }+ \text { Animal }+(\text { Dam }) & + \text { error [2] } \\
\mathrm{Y}_{\mathrm{f}}=\mu+\mathrm{HYS}+ & + \text { Common + Animal }+ & + \text { error [3] }
\end{array}
$$

Genetic analyses were performed with ASREML (Gilmour et al., 1999). 165 sires and 1039 dams produced the 29,200 piglets born, averaging 177 piglets per sire and 28 piglets per dam. 136 of these sires and 698 dams had tested offspring, averaging 20 tested boars per sire and almost 4 tested boars per dam.

\section{Results}

Descriptive statistics for the data set are given in Table 1. Traits were categorized as: (a) survival traits, (b) performance traits: gains in different weight intervals, backfat measurements and feed intake, and (c) derived traits: estimated protein and lipid depositions and estimated residual feed intake.

Average weight at the start of Phasel was $29 \mathrm{~kg}$, average weight at the end of Phasel $78 \mathrm{~kg}$, and average weight at the end of Phase $2130 \mathrm{~kg}$. Estimated protein- and especially lipid depositions were higher in the second phase of the test. Protein deposition increased from $141 \mathrm{~g} / \mathrm{d}$ during Phase 1 to $165 \mathrm{~g} / \mathrm{d}$ during Phase 2 and lipid deposition increased from $84 \mathrm{~g} / \mathrm{d}$ to $242 \mathrm{~g} / \mathrm{d}$, respectively. Average feed intake during Phase 2 was $2.75 \mathrm{~kg} / \mathrm{d}$ with a Phase2-gain of $999 \mathrm{~g} / \mathrm{d}$. The average residual feed intake was positive $(+140 \mathrm{~g} / \mathrm{d})$, indicating a higher feed intake than needed based on estimated maintenance requirements and protein and lipid depositions. 


\section{Genetic parameters of performance traits}

Heritabilities for gain ranged from 0.14 for Phase2-gain to 0.27 for Test-gain (Table 2). $\sigma_{\mathrm{G}}$ for Phase2-gain was higher $(73 \mathrm{~g} / \mathrm{d})$ than for test-gain $(56 \mathrm{~g} / \mathrm{d})$. Heritability estimates for protein deposition were 0.09 to 0.14 and for lipid deposition 0.33 to 0.51 for Phase2 and Testperiod, respectively.

Estimates of the proportion of common environment effects $\left(c^{2}\right)$ for gain and protein deposition were of the same magnitude as the estimates of the heritabilities.

Table 1: Descriptive statistics

\begin{tabular}{|c|c|c|c|c|c|}
\hline Trait $^{2}$ & No. & Mean & Std & Min & $\operatorname{Max}$ \\
\hline \multicolumn{6}{|l|}{ a Survival traits } \\
\hline Piglet survival (\%) & 29200 & 79.15 & & & \\
\hline Farrowing survival (\%) & 29200 & 93.16 & & & \\
\hline Pre-weaning survival (\%) & 29200 & 84.96 & & & \\
\hline Birth weight (kg) & 29200 & 1.42 & 0.36 & 0.3 & 3.0 \\
\hline \multicolumn{6}{|l|}{ b Performance traits } \\
\hline Weight at start (kg) & 2019 & 29 & 4.2 & 18 & 46 \\
\hline Weight end Phase $1(\mathrm{~kg})$ & 2648 & 78 & 9.6 & 45 & 110 \\
\hline Weight end Phase 2 (kg) & 2009 & 130 & 13.2 & 79 & 168 \\
\hline Early gain & 2051 & 364 & 49 & 228 & 536 \\
\hline Phase 1-gain & 2019 & 775 & 125 & 347 & 1233 \\
\hline Phase2-gain & 2009 & 999 & 199 & 131 & 1574 \\
\hline Test-gain & 1520 & 879 & 107 & 474 & 1172 \\
\hline Lifetime gain & 2653 & 654 & 95 & 307 & 924 \\
\hline Feed intake $(/ 1000)$ & 1623 & 2.75 & 0.45 & 1.07 & 4.37 \\
\hline Eating time (min/day) & 1622 & 67.8 & 15.4 & 31 & 168 \\
\hline Frequency (\# meals/day) & 1622 & 15.2 & 7.7 & 3 & 66 \\
\hline Phase1-backfat (mm) & 2670 & 7.7 & 0.95 & 5.2 & 12.0 \\
\hline Phase2-backfat (mm) & 2362 & 10.7 & 1.97 & 6.0 & 20.8 \\
\hline \multicolumn{6}{|l|}{ c Derived performance traits } \\
\hline Phase1-protein deposition & 2005 & 141 & 21 & 65 & 234 \\
\hline Phase2-protein deposition & 2004 & 165 & 32 & 26 & 301 \\
\hline Test-protein deposition & 1517 & 154 & 17 & 88 & 203 \\
\hline Phase 1-lipid deposition & 2005 & 84 & 30 & $\overline{14}$ & 240 \\
\hline Phase2-lipid deposition & 2004 & 242 & 99 & 0 & 721 \\
\hline Test-lipid deposition & 1517 & 151 & 52 & 31 & 168 \\
\hline Residual feed intake $(/ 1000)$ & 1602 & 143 & 311 & -1287 & 1336 \\
\hline
\end{tabular}


This implies that piglets resemble one another as much or more through their common environment as through their common genes.

\section{Correlations of performance traits with piglet survival and individual birth weight}

In Table 3 phenotypic and genetic correlations of performance traits with piglet survival and birth weight are presented. Genetic correlations of piglet survival with backfat measurements were clearly positive (0.4-0.5). Negative genetic correlations were found between protein deposition and survival, particularly with estimated protein deposition during Phase 2. Furthermore, high negative correlations of piglet survival were found with early gain and with residual feed intake. The genetic correlations of survival with gain showed an interesting pattern, changing from strongly negative for early gain, via moderately negative for Phase1-gain to slightly positive in Phase2-gain.

Table 2: Heritability $\left(h^{2}\right)$ and common environment $\left(c^{2}\right)$ estimates for performance traits.

\begin{tabular}{lccc}
\hline Trait $^{2}$ & $h^{2}$ & $c^{2}$ & $\sigma_{\mathrm{G}}^{2}$ \\
\hline Early gain & $0.17 \pm 0.04$ & $0.16 \pm 0.02$ & $440 \pm 129$ \\
Phase1-gain & $0.19 \pm 0.04$ & $0.10 \pm 0.03$ & $2294 \pm 797$ \\
Phase2-gain & $0.14 \pm 0.05$ & $0.20 \pm 0.03$ & $5362 \pm 1811$ \\
Test-gain & $0.27 \pm 0.07$ & $0.17 \pm 0.04$ & $3130 \pm 889$ \\
Lifetime gain & $0.19 \pm 0.04$ & $0.10 \pm 0.02$ & $2226 \pm 504$ \\
\hline Feed intake & $0.28 \pm 0.07$ & $0.08 \pm 0.04$ & $50684 \pm 12930$ \\
Eating time & $0.29 \pm 0.07$ & $0.13 \pm 0.04$ & $61 \pm 16$ \\
Frequency & $0.45 \pm 0.08$ & $0.04 \pm 0.03$ & $27 \pm 5$ \\
\hline Phasel-backfat & $0.51 \pm 0.06$ & $0.05 \pm 0.02$ & $0.31 \pm 0.054$ \\
Phase2-backfat & $0.41 \pm 0.06$ & $0.06 \pm 0.02$ & $1.1 \pm 0.189$ \\
\hline Phase1-protein deposition & $0.11 \pm 0.04$ & $0.14 \pm 0.03$ & $55 \pm 21$ \\
Phase2-protein deposition & $0.09 \pm 0.04$ & $0.19 \pm 0.04$ & $94 \pm 40$ \\
Test-protein deposition & $0.14 \pm 0.05$ & $0.18 \pm 0.03$ & $56 \pm 20$ \\
\hline Phase1-lipid deposition & $0.39 \pm 0.06$ & $0.05 \pm 0.03$ & $309 \pm 62$ \\
Phase2-lipid deposition & $0.33 \pm 0.06$ & $0.10 \pm 0.03$ & $2980 \pm 649$ \\
Test-lipid deposition & $0.51 \pm 0.08$ & $0.04 \pm 0.04$ & $1232 \pm 255$ \\
\hline Residual feed intake & $0.11 \pm 0.05$ & $0.12 \pm 0.04$ & $8389 \pm 4137$ \\
\hline
\end{tabular}

a For units see Table 1. 
The genetic correlations of birth weight with performance traits showed a rather different picture. Correlations with backfat were negative and with protein depositions positive, especially with Phase2-protein deposition $(0.40)$.

\section{Direct-nurse sow model for pre-weaning survival}

In Table 4 a more detailed genetic model was used to analyze pre-weaning survival. Animal effects fitted were the direct and the nurse sow effects. The estimated heritability for the direct effect was $0.020 \pm 0.009$, and for the nurse sow effect $0.027 \pm 0.006$, with a genetic correlation between the two of $-0.31 \pm 0.22$.

Table 3: Phenotypic and genetic correlations of performance traits with piglet survival and birth weight estimated with a direct animal effect model.

\begin{tabular}{|c|c|c|c|c|}
\hline \multirow[b]{2}{*}{ Trait } & \multicolumn{2}{|c|}{ Piglet survival $^{\mathrm{a}}$} & \multicolumn{2}{|c|}{ Birth weight ${ }^{b}$} \\
\hline & $\begin{array}{l}\text { Phenotypic } \\
\text { Correlation }\end{array}$ & $\begin{array}{c}\text { Genetic } \\
\text { Correlation }\end{array}$ & $\begin{array}{l}\text { Phenotypic } \\
\text { Correlation }\end{array}$ & $\begin{array}{c}\text { Genetic } \\
\text { Correlation }\end{array}$ \\
\hline Early gain & $-0.73 \pm 0.01$ & $-0.64 \pm 0.11$ & $0.32 \pm 0.02$ & $0.16 \pm 0.14$ \\
\hline Phase 1-gain & $-0.56 \pm 0.02$ & $-0.21 \pm 0.19$ & $0.14 \pm 0.03$ & $0.00 \pm 0.16$ \\
\hline Phase2-gain & $-0.05 \pm 0.03$ & $0.08 \pm 0.19$ & $0.10 \pm 0.03$ & $0.19 \pm 0.16$ \\
\hline Test-gain & $-0.04 \pm 0.04$ & $0.24 \pm 0.17$ & $0.15 \pm 0.03$ & $0.12 \pm 0.14$ \\
\hline Lifetime gain & $-0.57 \pm 0.02$ & $-0.25 \pm 0.14$ & $0.20 \pm 0.02$ & $0.04 \pm 0.12$ \\
\hline Feed intake & $-0.11 \pm 0.03$ & $0.08 \pm 0.16$ & $0.07 \pm 0.03$ & $-0.12 \pm 0.13$ \\
\hline Eating time & $0.12 \pm 0.03$ & $-0.03 \pm 0.16$ & $-0.02 \pm 0.03$ & $0.10 \pm 0.13$ \\
\hline Frequency & $-0.05 \pm 0.03$ & $0.11 \pm 0.14$ & $-0.01 \pm 0.03$ & $-0.22 \pm 0.11$ \\
\hline Phase1-backfat & $0.41 \pm 0.02$ & $0.36 \pm 0.10$ & $-0.15 \pm 0.02$ & $-0.05 \pm 0.09$ \\
\hline Phase2-backfat & $0.54 \pm 0.02$ & $0.52 \pm 0.10$ & $-0.21 \pm 0.03$ & $-0.20 \pm 0.10$ \\
\hline Phase1-protein deposition & $-0.48 \pm 0.03$ & $-0.34 \pm 0.19$ & $0.17 \pm 0.03$ & $0.08 \pm 0.17$ \\
\hline Phase2-protein deposition & $-0.41 \pm 0.02$ & $-0.46 \pm 0.19$ & $0.16 \pm 0.03$ & $0.40 \pm 0.18$ \\
\hline Test-protein deposition & $-0.55 \pm 0.02$ & $-0.27 \pm 0.19$ & $0.23 \pm 0.03$ & $0.31 \pm 0.16$ \\
\hline Phase1-lipid deposition & $0.04 \pm 0.03$ & $0.13 \pm 0.14$ & $0.03 \pm 0.03$ & $-0.07 \pm 0.11$ \\
\hline Phase2-lipid deposition & $0.06 \pm 0.03$ & $0.36 \pm 0.13$ & $-0.02 \pm 0.03$ & $-0.13 \pm 0.12$ \\
\hline Test-lipid deposition & $0.09 \pm 0.03$ & $0.40 \pm 0.12$ & $0.00 \pm 0.03$ & $-0.05 \pm 0.13$ \\
\hline Residual feed intake & $-0.07 \pm 0.03$ & $-0.64 \pm 0.19$ & $0.08 \pm 0.03$ & $-0.00 \pm 0.20$ \\
\hline
\end{tabular}

${ }^{\mathrm{a}}$ Estimate for $\mathrm{h}^{2}$-direct effect piglet survival $0.095 \pm 0.016 ;{ }^{b}$ Estimate for $\mathrm{h}^{2}$-direct effect birth weight $0.326 \pm 0.025$ 
Genetic correlations of the direct effect of pre-weaning survival with performance traits were, on average, moderately positive. Piglets with a good genotype for preweaning survival had clearly higher appetites, higher backfat measurements, and higher estimated lipid depositions. Genetic correlations of mothering ability with feed intake, frequency (number of meals per day), eating time, and Phase2-protein deposition were all negative.

Birth weight was analyzed with a direct-maternal model and yielded heritabilities of $0.059 \pm 0.015$ for the direct, and $0.172 \pm 0.017$ for the maternal effect, with a genetic correlation between the two of $-0.22 \pm 0.16$. The genetic correlation between the maternal effect for birth weight and Phase2-protein deposition was moderate (0.46), and with Phase1-protein deposition effectively zero, suggesting that sows with a somewhat postponed protein deposition, possibly later maturing, will give heavier piglets.

These two correlations were reversed for the direct effect; there was a strong positive genetic correlation between the direct effect of birth weight and Phasel-protein deposition (0.53), and a non-significant negative correlation between the direct effect and Phase2-protein deposition $(-0.20)$.

\section{Discussion}

The objective of the present analyses was to investigate the relationship between piglet survival, birth weight and performance traits. Piglet survival and birth weight data were recorded on all piglets born in the period of analysis.

Performance traits, however, were measured only on males, pre-selected to undergo test on a pedigree index of performance traits and survival. Ideally a multivariate analysis should have been performed, including all traits simultaneously. Since this is technically not possible, bi-variate analyses have been used. In most analyses the larger part of the pre-selection has been accounted for, since the traits analyzed were part of the selection index.

\section{Performance traits}

Heritabilities for performance traits were within the range of the literature. Results presented here (literature review estimates from Clutter and Brascamp, 1999, are shown in parentheses) were 0.14-0.27 (0.31) for different phases of gain, 0.41-0.51 (0.49) for backfat and $0.28(0.29)$ for feed intake. Heritabilities for gains, estimated in Phasel, Phase2, and Test were $0.19,0.14$ and 0.27 . Genetic variance in Phase 2 was higher than 
the variance in the overall Test period while the estimated heritability in Phase 2 was lower (Table 2). Phenotypic variation in backfat at the end of Phase 2 was twice as high as at the end of Phasel (Table 1).

Table 4: Genetic correlations of performance traits with pre-weaning survival (animal effects; direct and nurse sow) and birth weight (animal effects: direct and maternal).

\begin{tabular}{lcc|cc}
\hline & \multicolumn{2}{c|}{ Pre-weaning survival ${ }^{\mathrm{a}}$} & \multicolumn{2}{c}{ Birth weight $^{\mathrm{b}}$} \\
\hline & direct & Nurse sow & Direct & Maternal \\
\hline Early gain & $-0.23 \pm 0.25$ & $-0.44 \pm 0.18$ & $0.05 \pm 0.21$ & $0.29 \pm 0.14$ \\
Phase1-gain & $0.25 \pm 0.30$ & $0.08 \pm 0.22$ & $0.53 \pm 0.20$ & $-0.05 \pm 0.17$ \\
Phase2-gain & $0.38 \pm 0.26$ & $-0.41 \pm 0.21$ & $-0.12 \pm 0.22$ & $0.31 \pm 0.17$ \\
Test-gain & $0.43 \pm 0.24$ & $-0.15 \pm 0.19$ & $0.10 \pm 0.22$ & $-0.22 \pm 0.15$ \\
Lifetime gain & $0.29 \pm 0.23$ & $-0.29 \pm 0.16$ & $-0.07 \pm 0.19$ & $0.24 \pm 0.12$ \\
\hline Feed intake & $0.44 \pm 0.22$ & $-0.30 \pm 0.17$ & $0.10 \pm 0.22$ & $0.22 \pm 0.15$ \\
Eating time & $0.15 \pm 0.23$ & $-0.23 \pm 0.17$ & $-0.26 \pm 0.19$ & $0.21 \pm 0.14$ \\
Frequency & $-0.20 \pm 0.21$ & $-0.43 \pm 0.19$ & $-0.03 \pm 0.17$ & $-0.33 \pm 0.11$ \\
\hline Phasel-backfat & $0.41 \pm 0.19$ & $-0.31 \pm 0.22$ & $0.18 \pm 0.16$ & $-0.18 \pm 0.10$ \\
Phase2-backfat & $0.51 \pm 0.18$ & $0.18 \pm 0.15$ & $0.05 \pm 0.17$ & $-0.25 \pm 0.11$ \\
\hline Phase1-protein deposition & $0.11 \pm 0.32$ & $0.04 \pm 0.24$ & $0.53 \pm 0.22$ & $0.02 \pm 0.18$ \\
Phase2-protein deposition & $0.20 \pm 0.33$ & $-0.63 \pm 0.24$ & $-0.20 \pm 0.25$ & $0.46 \pm 0.18$ \\
Test-protein deposition & $0.19 \pm 0.30$ & $-0.24 \pm 0.22$ & $0.22 \pm 0.24$ & $0.29 \pm 0.17$ \\
\hline Phase1-lipid deposition & $0.37 \pm 0.21$ & $0.00 \pm 0.16$ & $0.28 \pm 0.18$ & $-0.11 \pm 0.12$ \\
Phase2-lipid deposition & $0.44 \pm 0.19$ & $-0.05 \pm 0.17$ & $-0.03 \pm 0.18$ & $-0.02 \pm 0.13$ \\
Test-lipid deposition & $0.50 \pm 0.18$ & $-0.01 \pm 0.16$ & $0.00 \pm 0.18$ & $-0.03 \pm 0.12$ \\
\hline Residual feed intake & $-0.64 \pm 0.28$ & $-0.06 \pm 0.25$ & $-0.27 \pm 0.28$ & $0.19 \pm 0.21$ \\
\hline & & $-w 18$ & \\
\hline
\end{tabular}

${ }^{2}$ Estimates for $\mathrm{h}^{2-}$ direct effect of pre-weaning survival $0.020 \pm 0.009$, for $\mathrm{h}^{2}$-nurse sow effect

$0.027 \pm 0.006$ and for the genetic correlation between the two, $-0.31 \pm 0.22 ;{ }^{b}$ Estimates for $\mathbf{h}^{2-}$ direct effect of birth weight $0.059 \pm 0.015$, for $h^{2}$-maternal effect $0.172 \pm 0.017$ and for the genetic correlation between the two, $-0.22 \pm 0.16$.

However, the heritability of backfat at the end of Phasel was at least as high as the heritability at the end of Phase 2 . The genetic correlation between the two was high $(0.86)$ (result not shown). If gain is partitioned into protein and lipid deposition, lipid deposition clearly has the higher heritability. $\sigma_{G}$ for Phase2-protein deposition was $9.7 \mathrm{~g} / \mathrm{d}$, compared with the $73 \mathrm{~g} / \mathrm{d}$ for Phase-2 gain and $55 \mathrm{~g} / \mathrm{d}$ for Phase2-lipid deposition. 
Kennedy et al. (1993) addressed the question of the benefit of analyzing derived traits and concluded that an index of derived traits was not superior to a well designed index of the original traits. The benefit of calculating derived traits lies in the better understanding of the origin of variation in growth. The data show that it will be difficult to increase protein deposition genetically, since genetic variance was small, heritabilities low and the effect of common environment high. Selection for increased gain will, therefore, mainly influence lipid deposition. Still, the data suggest that protein deposition is a trait that offers additional information over gain. For example, birth weight seems more closely related to protein deposition than to gain.

Genetic correlations between piglet survival and pre-weaning survival on one side and performance traits on the other

Piglet survival is the product of farrowing survival and pre-weaning survival. Piglet survival was modeled with a direct genetic effect (vitality of the piglet). Pre-weaning survival was modeled with a direct and nurse sow effect (mothering ability).

Mersmann et al. (1984) found pre-weaning survival rates of $93 \%$ in an obese and 76 $\%$ in a lean line of sows and attributed the increased survival more to the piglet than to the nurse sow. McKay (1993) reported that index selection for reduced backfat thickness and increased growth rate increased pre-weaning death losses, for a large part through a decrease in mothering ability. Kerr and Cameron (1995) found a significant correlated negative response $(-14 \%)$ in pre-weaning survival after 5 generations of selection for lean gain under scale feeding; under ad libitum feeding the response was negative too ( -5 $\%$ ), but not significant. Their high lean gain selection line gave a higher mortality (nonsignificant). The findings of Mersmann et al. (1984) are in line with the current correlations (Table 4), where the genetic correlation between both backfat measurements and the direct effect of pre-weaning survival was 0.41-0.51.

For mothering ability no significant correlation was found. McKay 's (1993) results could be explained through a combination of the negative genetic correlation between gain and mothering ability and the positive correlation between backfat and the direct effect of pre-weaning survival. Selection for decreased backfat will harm piglet vitality and selection for increased gain will have negative consequences for mothering ability. The results of Kerr and Cameron (1995) are in line with the present results; their high lean growth lines had a decreased survival. 
Table 5: Genetic regression coefficients of survival and birth weight expressed as percentage survival $/ \sigma_{g}$ and gram birth weight $/ \sigma_{g}$ of the trait concerned

\begin{tabular}{|c|c|c|c|c|c|c|}
\hline \multirow{3}{*}{$\begin{array}{l}\text { Trait } \\
\text { Model } \\
\text { Effect }\end{array}$} & \multicolumn{3}{|c|}{ Survival } & \multicolumn{3}{|c|}{ Birth weight } \\
\hline & \multirow{2}{*}{$\begin{array}{l}\text { Direct } \\
\text { Direct" }\end{array}$} & \multicolumn{2}{|c|}{ Direct/nurse sow } & \multirow{2}{*}{$\begin{array}{l}\text { Direct } \\
\text { Direct } \\
\end{array}$} & \multicolumn{2}{|c|}{ Direct/maternal } \\
\hline & & Direct $^{b}$ & Nurse sow & & Direct $^{b}$ & Maternal \\
\hline Early gain & -7.4 & -1.1 & -2.4 & 32 & 4 & 42 \\
\hline Phasel-gain & -2.9 & 1.2 & 0.4 & 0 & 43 & -7 \\
\hline Phase2-gain & 0.9 & 1.8 & -2.3 & 38 & -10 & 45 \\
\hline Test-gain & 2.8 & 2.1 & -0.8 & 24 & 8 & -31 \\
\hline Lifetime gain & -2.8 & 1.4 & -1.6 & 8 & -6 & 35 \\
\hline Feed intake & 0.9 & 2.1 & -1.7 & -24 & 8 & 32 \\
\hline Eating time & -0.3 & 0.7 & -1.3 & 20 & -21 & 31 \\
\hline Frequency & 1.3 & -1.0 & -2.4 & -44 & -2 & -48 \\
\hline Phasel-backfat & 4.2 & 2.0 & -1.7 & -10 & 15 & -26 \\
\hline Phase2-backfat & 6.0 & 2.4 & 1.0 & -40 & 4 & -37 \\
\hline Phase 1-protein deposition & -3.9 & 0.5 & 0.2 & 16 & 43 & 3 \\
\hline Phase2-protein deposition & -5.3 & 1.0 & -3.5 & 81 & -16 & 67 \\
\hline Test-protein deposition & -3.1 & 0.9 & -1.3 & 63 & 18 & 42 \\
\hline Phase1-lipid deposition & 1.5 & 1.8 & 0.0 & -14 & 23 & -16 \\
\hline Phase2-lipid deposition & 4.2 & 2.1 & -0.3 & -26 & -2 & -3 \\
\hline Test-lipid deposition & 4.6 & 2.4 & -0.1 & -10 & 0 & -4 \\
\hline Residual feed intake & -7.4 & -3.1 & -0.3 & 0 & -22 & 28 \\
\hline
\end{tabular}

\footnotetext{
${ }^{3}$ Piglet survival and birth weight were modeled with a direct effect as the only animal factor (see Table 3);

${ }^{b}$ Pre-weaning survival and birth weight were modeled with a direct effect and nurse sow effect, and with a direct effect and maternal effect as animal factors, respectively (see Table 4).
}

Correlations can be significant, but not necessarily relevant. In Table 5 genetic regression coefficients are given per genetic std of a trait. The genetic regression of preweaning survival on backfat was $2.0 \%$ survival per genetic std of backfat measured at the end of Phasel and $2.4 \%$ per genetic std at the end of Phase2 (Table 5), if piglet survival is modeled with a direct effect-nurse sow model. Regression coefficients were even higher for piglet survival, modeled with a direct effect of the piglet only. The genetic correlations of residual feed intake with piglet survival in the direct effect model (Table 3) and with the direct effect of pre-weaning survival (Table 4) were highly negative, indicating higher survival rates for energetically more efficient animals. This again is in agreement with Kerr and Cameron (1995), who found a higher pre-weaning mortality in their high lean food conversion line. This negative genetic correlation was 
contrary to expectation; the trait 'residual feed intake" estimates the amount of feed intake surplus to requirements for average maintenance and for lipid and protein deposition. Low values for lower levels of activity, lower heat production may explain residual feed intake, lower level of disease resistance etc. A genetic decrease in residual feed intake could therefore have negative consequences for survival. On the other hand, if all processes in the body function without disruption, both efficiency and piglet survival will benefit. Kerr and Cameron (1995) stated: '.. the high food conversion ratio and low daily food intake selection lines had impaired reproductive performance.' Litter size was reduced and mortality increased. The effect of selection against residual feed intake could, per genetic std, result in an increase of $7 \%$ in the direct effect of piglet survival or $3.1 \%$ in the direct effect of pre-weaning survival (Table 5). Feed intake was measured in Phase 2 of the test and piglet survival in the first three weeks of life. There were large differences in the respective rearing environments, and it is therefore possible that there is another explanation for the negative relationship between residual feed intake and survival. In the current analyses derived traits were calculated using literature values for maintenance and protein and lipid deposition efficiencies. This was somewhat different from the approach of de Haer et al. (1993), who estimated the costs of maintenance and depositions in the data set itself, forcing the average residual feed intake to be zero.

The results of Tables 3 and 4 indicate an effect of selection for survival on growth pattern. In both approaches the genetic correlations of survival with early gain were negative, with Phase2-gain positive, and with Phase-1 gain intermediate. This suggests that selection for survival will lead to piglets which grow slower in the early phases of life and faster in the late phases, which corresponding to weight curves with a higher adult weight (Taylor, 1982). The genetic correlations with protein and lipid deposition, however, do not support this hypothesis. The genetic correlations of protein deposition in both Phases and in the overall test period with the direct effect of piglet survival have a negative sign (Table 3), while the lipid depositions share a positive sign. The suggested difference in growth pattern is then merely a function of changes in protein and lipid deposition.

Table 4 yields information on the performance qualities of a good nursing sow. Most of the genetic correlations between performance traits and mothering ability were negative, whereas most of the genetic correlations with piglet vitality were positive. 
Selection for mothering ability will yield animals with, in general, a somewhat lower gain, similar backfat, and a lower appetite during the test phase of life. Van Erp et al. (1998) estimated the genetic correlation between feed intake during test and feed intake during lactation as $0.92 \pm 0.5$. If this high correlation is true, it creates an interesting dilemma. The necessity for increased mothering ability increases with successful selection for increased litter size. A major limiting factor for improvement of reproduction is lactation feed intake (Eissen et al., 2000). A low feed intake during lactation and a high demand for milk of the piglets will deplete the energy and protein reserves of a sow, resulting in a prolonged interval from weaning to oestrus. An increase in litter size will increase the milk demand by the piglets and increase weight loss in the sow. According to the current results, selection for increased feed intake during the growing phase is not likely to improve the survival chances of piglets and might even adversely influence these $\left(r_{\mathfrak{g}}=-0.30 \pm 0.17\right.$, Table 4). The genetic correlations of mothering ability and Phase2-gain and Phase2-protein deposition were moderately to highly negative. Selection for sows with a high protein deposition in the later phases of the test will reduce mothering ability. The genetic regression of mothering ability per genetic std of protein deposition was $-3.5 \%$ survival attributable to mothering ability (Table 5).

Tables 3 and 4 both give estimates of genetic correlations between performance traits and survival. In Table 3 the survival trait considered was pigiet survival, including farrowing survival, and in Table 4 it was pre-weaning survival only. The second difference was the inclusion of nurse sow in the model for pre-weaning survival. The two most extreme correlations had the same value in both Tables, residual feed intake with a value of -0.64 and Phase2-backfat with a value of 0.52 . Quite large differences in genetic correlations were found with the protein deposition estimates, feed intake and life daily gain. In all situations the genetic correlation of survival with performance traits was higher in the pre-weaning analysis. It is unclear whether this was caused by the exclusion of farrowing survival from piglet survival or the introduction of nurse sow in the model for pre-weaning survival.

\section{Correlations of birth weight with performance traits}

Increasing birth weight has been proposed as a means to increase piglet survival (Kerr and Cameron, 1995; Roehe and Kalm, 2000). The genetic regulation of birth weight, 
however, is mainly maternal (Roehe, 1999 and Kaufmann et al., 2000). The results of Table 4 are therefore more relevant in this respect than those of Table 3. The genetic correlations of birth weight with backfat measurements were negative and with growth traits positive. Selection for lean tissue daily gain in sows will therefore result in heavier piglets. This is in agreement with the results of Mersmann et al. (1983). Their lean line of sows produced piglets of $1.3 \mathrm{~kg}$; their obese line gave birth to piglets of $1.1 \mathrm{~kg}$. Gaughan et al. (1995) categorized sows on the basis of their phenotype into three groups using backfat depth; the lean group had $12.2 \mathrm{~mm}$ and the fat group with $18.5 \mathrm{~mm}$. The lean group gave birth to piglets with an average birth weight of $1.51 \mathrm{~kg}$ and the fat group with $1.32 \mathrm{~kg}$. Kerr and Cameron (1995) saw an increase in both litter weight and average birth weight in their scale feeding lean growth selection line, but no change in litter size. Furthermore they found a decrease in average birth weight in their ad libitum lean growth selection line. The genetic correlation of the maternal component of birth weight and estimated protein deposition in the present study is $0.46 \pm 0.18$, which is moderately high. One genetic std of Phase2-protein deposition is predicted to yield 67 gram of birth weight (Table 5).

The genetic correlation between individual birth weight and piglet survival was $0.00 \pm 0.13$, if both traits were modeled with a direct effect only (result not shown).

It is concluded that selection for heavier piglets at birth will give correlated responses in terms of higher protein deposition and leaner carcasses.

\section{Implications}

A genetic relationship exists between birth weight and survival on one side and performance traits on the other. Birth weight is a mainly maternal trait, and this maternal animal effect has a positive genetic correlation with lean gain. Selection for improved piglet survival will increase feed intake, gain, and backfat and will decrease residual feed intake. Selection for improved mothering ability will decrease gain, feed intake and in particular, estimated protein deposition in the later phase of the testing period. In a selection program aimed at increasing production efficiency it is necessary to include survival traits 


\section{Acknowledgements}

The authors thankfully acknowledge the help of Karel de Greef for his comments on the manuscript. This research was financially supported by The Netherlands Technology Foundation (STW).

\section{References}

Bedrijfsvergelijking SIVA software BV, 1999. Kengetallenspiegel. Available at: http://www.siva.nl/nl/result/rzlan99.htm. Accessed at: July 3, 2000.

Clutter A.C., and E.W. Brascamp. Genetics of performance traits. 1998. In: M.F. Rothschild and A. Ruvinsky (ed) Genetics of the pig. p 427-462. CAB International, Oxon, UK.

Eissen, J. J., E. Kanis, and B. Kemp. 2000. Sow factors affecting voluntary feed intake during lactation. Livest. Prod. Sci. 64:1372-1378.

De Greef, K. H., M. W.A. Verstegen, B. Kemp, and P. L. van der Togt. 1994. The effect of body weight and energy intake on the composition of deposited tissue in pigs. Anim. Prod. 58:263-270.

De Haer, L., L.C.M. Luiting, and H.L.M. Aarts. 1993. Relations among individual (residual) feed intake, growth performance and feed intake pattern of growing pigs in group housing. Livest. Prod. Sci. 36:223-232.

Gaughan, J.B., R.D.A. Cameron, G.McL. Dryden, and M.J. Josey, 1995. Effect of selection for leanness on overall reproductive performance in Large White sows. Anim. Sci. 61:561-564.

Gilmour, A.R., B.R. Cullis, and S.J. Welham, and R. Thompson. 1999. ASREML. NSW Agriculture, occasional publication.

Herpin, P., and J.C. Hulin. 2000. Effect of birth weight on thermoregulatory abilities of Chinese (Meishan) and European (Large $x$ Piétrain) newborn piglets. In: Proceedings of the 15th Symposium on Energy Metabolism of Animals;10-16 sept. 2000; Elsinore, DK. (in press)

Herpin, P., J. Le Dividich, and N. Amaral. 1993. Effect of selection for lean tissue growth on body composition and physiological state of the pig at birth. J. Anim. Sci. 71:26452653. 
Kaufmann, D., A. Hofer, J. P. Bidanel, and N. Künzi. 2000. Genetic parameters for individual birth and weaning weight and for litter size of Large White pigs. J.Anim. Breed. Genet. 117: 121-128.

Kennedy, B.W., J.H.J. van der Werf, and T.H.E. Meuwissen. 1993. Genetic and statistical properties of residual feed intake. J. Anim. Sci. 71:3239-3250.

Kerr, J.C., N. D. Cameron. 1995. Reproductive performance of pigs selected for components of efficient lean growth. Anim. Sci. 60:281-290.

Knol, E.F. 2001 a. Genetic parameters of litter mortality in pigs (submitted)

Knol E.F., B.J. Ducro, J.A.M. van Arendonk, and T. van der Lende. 2001b. Direct, maternal and nurse sow genetic effects on farrowing-, pre-weaning- and total piglet survival (submitted).

McKay R. M. 1993. Preweaning losses of piglets as a result of index selection for reduced backfat thickness and increased growth rate. Can. J. Anim. Sci. 73: 437-442.

Mersmann, H.J., W.G. Pond, R.T. Stone, J.T. Yen, and R.N. Lindvall. 1984. Factors affecting growth and survival of neonatal genetically obese and lean swine: cross fostering experiments. Growth 48:209-220.

PigCHAMP database, 1998. Swine data management's Pigchamp record service. Available at: http://www.netins.net/showcase/swinedata. Accessed July 3, 2000.

Roehe, R., 1999. Genetic determination of individual birth weight and its association with sow productivity traits using bayesian analyses. J. Anim. Sci. 77:330-343.

Rothschild, M.F., and J.P. Bidanel. 1998. Biology and genetics of reproduction. In: M.F. Rothschild and A. Ruvinsky (ed) Genetics of the pig. p 323. CAB International, Oxon, UK.

Taylor, St.C.S. 1982. Use of genetic size-scaling in evaluation of animal growth. International Symposium on "Current Concepts of Animal Growth". Guelph, 1982.

Van Erp, A.J.M., R.J.F. Molendijk, J.J. Eisen, and J.W.M. Merks, 1998. Relation between ad libitum feed intake of gilts during rearing and feed intake capacity of lactating sows. In: 49th Annual Meeting EAAP, G5.10 (abst.), Warsaw, Poland. pp42. 
Appendix 1:

Formulas used for the estimation of protein-, lipid deposition and residual feed intake.

$\%$ fat $=\frac{\text { ultrasonicbackfat }(\mathrm{mm})-1.87}{53.3}$

$\%$ protein $=0.165-\left\{0.00025 *\left(\frac{\text { Startweight }+ \text { finalweight }}{2}-80\right)\right\}$

Maintenance $=\frac{\left(\text { Finalweight }^{1.75}-\text { startweight }^{1.75}\right) * 420}{(\text { Finalweight }- \text { startweight }) * 1.75}$ (De Haer,1993)

Water_protein_ratio $=5.39 *\left(\% \text { protein } * \frac{\text { Startweight }+ \text { finalweight }}{2}\right)^{-0.145}($ De Greef, 1994)

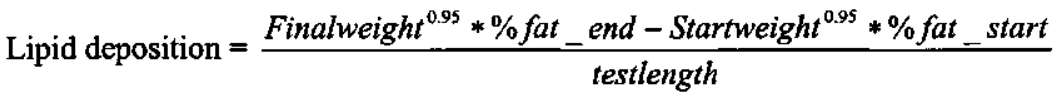

Protein deposition $=\frac{\text { Dailygain }- \text { Lipiddeposition }}{\text { Water_protein_ratio }+1}$

$\mathrm{RFI}=$ Residual feed intake

$\mathrm{RFI}=$ Feedintake $* 13.5-$ maintenance $-($ Proteindeposition + lipiddeposition $) * 53$ 
Piglet losses were classified as:

(e) euthanized - piglets that were humanely destroyed because of debilitating conditions (i.e. born without an anus, sever sply-leggedness or body tremors);

McKay (1993) 


\section{Discussion}

The main goal of this thesis was to find out whether selection for increased piglet survival is possible will beand effective. Piglet survival was analyzed as a trait of the dam, as a trait of the piglet and as a combination of the two. Estimated parameters were tested in two data sets. In paragraph 6.1 , the results of the litter, piglet and prediction approaches are summarized and the results compared with the literature. In subsequent paragraphs a number of remaining questions are addressed:

Is it worthwhile to differentiate piglet survival in farrowing and pre-weaning survival (6.2)?

Is mothering ability genetically important and how should it be approached (6.3)?

The phenotypic correlation between birth weight and survival of piglets is clearly positive. Will selection on birth weight result in an increase in survival (6.4)?

Current results indicate that selection for increased survival will increase survival at a given birth weight and will reduce variation in birth weight. Findings in The Meishan breeds of pigs show improved survival at a given birth weight and also a reduction in variation in birth weight. Is this resemblance a coincidence, or are the findings in the Meishan breed more relevant for commercial lines than expected (6.5)?

How relevant are current results for expected trends in performance traits and will selection for survival markedly influence performance traits (6.6)?

What selection strategies will optimize the yield of a balanced and economic improvement in reproduction traits $(6.7)$ ?

A generalized conclusion will end the discussion (6.8). 


\subsection{Summary of the genetic results}

Piglet survival was defined as the probability of a piglet surviving from late gestation to weaning. The time period over which survival was measured included farrowing, which is considered a critical event for the piglet. Piglet survival did not include nonfresh stillborn piglets or mummified piglets. Cross-fostering was recorded and survival could be traced back to the biological mother. In Figure 1, a schematic representation of traits and genotypes is given. A specific sow has a litter of nine piglets. One of the piglets

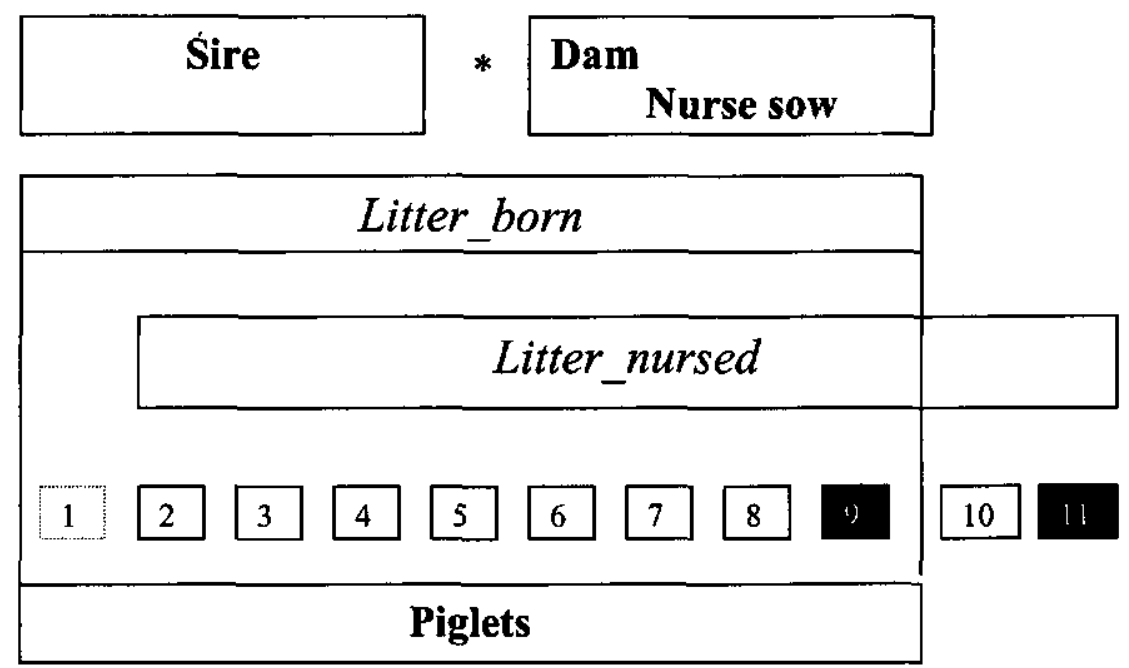

\begin{tabular}{lccc}
\hline Trait & Value & Genotype \\
\hline Litter size dam & 9 & \\
\#stillborn & 1 & \\
Farrowing survival & $(8 / 9)$ & $88.9 \%$ & Dam \\
Pre-weaning survival (7/8) & $87.5 \%$ & Dam \\
Litter survival & $(7 / 9)$ & $77.8 \%$ & Dam \\
\#Cross-fostered to the dam & 2 & \\
Litter for nursing & & 10 & \\
Mothering ability & $(8 / 10)$ & $80.0 \%$ & Nurse sow \\
\hline
\end{tabular}

Figure 1: Schematic representation of different traits (see Table in Figure) and sow genotypes (in bold) involved in piglet survival (dotted square: stillborn piglet, black square: piglet died before weaning, open square: piglet weaned). Sire and piglet genotypes are ignored in the Table. 
was stillborn (\#1) and seven of the remaining eight piglets survived to weaning. In this situation, farrowing survival was $88.9 \%$, pre-weaning survival $87.5 \%$, and piglet survival $77.8 \%$. The nurse sow effect or mothering ability of this sow was $80 \%$, eight piglets were live-born, two piglets were cross-fostered to the sow (\#10 and \#11) and eight piglets were still alive at weaning. In Chapter 2 , analyses were performed in which piglet survival was considered a trait of the dam. The trait was litter survival (litter mortality), and was calculated as a percentage of weaned piglets from the original litter (litter_born).

Table 1: Estimated heritabilities for farrowing-, pre-weaning-, and piglet survival showing different approaches to address survival. Analyses were with a sire or an animal model, on an individual piglet- or on a litter level, binomial or on the underlying scale.

\begin{tabular}{lcllll}
\hline Authors & Year & Trait & $\begin{array}{l}\text { Level of } \\
\text { analysis }\end{array}$ & $\begin{array}{l}\text { Animal } \\
\text { effect }\end{array}$ & Estimate \\
\hline Kerr and Cameron & 1995 & Pre-weaning surval & Litter & Sire+Dam & $0.04^{\top}$ \\
Van Arendonk et al. & 1996 & Piglet survival & Piglet & Dam & 0.09 \\
& & Piglet survival & Piglet & Piglet & 0.11 \\
Siewerdt and Cardellino & 1996 & Farrowing survival & Litter & Dam & 0.00 \\
& & Pre-weaning surval & Litter & Dam & 0.05 \\
Rothschild and Bidanel & 1998 & Pre-weaning survival & Review & Dam & 0.05 \\
Roehe and Kalm & 2000 & Pre-weaning survival & Piglet & Sire & 0.02 \\
Lund et al. & 2000 & Pre-weaning survival & Litter & Dam & 0.08 \\
& & Pre-weaning survival & Litter & Piglet & 0.04 \\
Grandinson et al. & 2000 & Farrowing survival & Piglet & Piglet & 0.27 \\
& & Piglet survival & Piglet & Piglet & 0.04 \\
\hline
\end{tabular}

This resulted in an estimated heritability for piglet survival of $0.06 \pm 0.01$. This estimate is in line with literature estimates as given in Table 1. Sire (that is, sire of the litter) effect was small (the ratio between sire variance and total variance was $0.012 \pm 0.003$ ).

From Table 1 it is clear that, in the literature, piglet survival has not been analyzed in a uniform way. Piglet survival has been treated as one trait or as two separate traits, as a binomial or as a continuous variable, and has been analyzed on a piglet, a sire and on a 
litter (dam) basis. In addition, confounding of maternal and nurse sow effects might be a problem. It is not always clear whether and how cross-fostering was accounted for. Kerr and Cameron (1995) stated very clearly that no cross-fostering was performed, which is reasonable for their experimental situation. Lund et al. (2000) analyzed field data and excluded litters in which cross-fostering was performed, but lost very few records. On the farms in our data set cross-fostering was common practice, and even though only 6-18\% of piglets were cross-fostered, it affected one-third to two-thirds of the litters (Table 2 in Chapter 3).

Piglet survival may be genetically correlated with litter traits such as litter size, litter weight, average birth weight, variation in birth weight and gestation length. Litter size and litter weight are highly positively correlated (Rothschild and Bidanel, 1995; Roehe, 1999). Litter size and average birth weight are negatively correlated (Chapter 2). The estimated heritability of piglet survival could be an analytical artifact due to a phenotypic correlation with another clearly heritable trait. For example, selection for survival could decrease litter size and increase birth weight and could therefore increase survival without affecting the piglets intrinsic ability to survive. A genetic analysis of survival could then pick up genetic variation in litter size. However, this does not seem to be the case. After correction for these litter traits, heritability for litter survival remained at the same level, as did the genetic variance (Chapter 2).

Genetic correlations of variation in birth weight and piglet survival were moderately negative ( -0.3$)$, both before and after correction for other litter traits. Heritability of variation in birth weight was 0.07 , which is in the same range as the heritabilities of total number born and piglet survival.

These genetic parameters, heritabilities and genetic correlations, show that genetic progress in piglet survival at the sow level is possible. Selection against variation in birth weight is possible and will help to increase survival.

The genetic contribution of the sire to piglet survival was small. In the analyses of Chapter 2, service sire was introduced as an unrelated random effect and not as an animal effect (i.e. relationships between animals were ignored). In a later phase the full pedigree was added to the service sire effect, but results remained unchanged $\left(\mathrm{h}^{2}=0.011 \pm 0.003\right)$. This heritability is similar to the one estimated by Roehe and Kalm (2000). The genetic correlation between sow and sire effects was $0.39 \pm 0.17$, indicating that the two animal effects address at least partially the same trait. The sow effect includes the influence of 
the sow by means of uterine quality and her contribution to the genotype of the piglet. The sire only influences the genotype of the piglet.

In Chapter 3 the piglet was the subject of interest. Models used for analysis included a direct effect of the piglet, a maternal effect and a nurse sow effect. In the ideal situation survival variance would be distributed over the three components. We did not succeed in obtaining estimates using this approach for the trait piglet survival. One of the explanations was the low degree of cross-fostering, making it hard to distinguish between maternal and nurse sow effects. Another explanation is the relative complexity of the analysis. Records of stillborn piglets included details of sire and dam, but obviously not ot the nurse sow. This phenomenon causes missing values in the equations used for the genetic analysis of piglet survival.

Piglet survival is the product of farrowing survival and pre-weaning survival. For farrowing survival in a dam line, a model with only the direct effect fitted the data best, whereas in a sire line a direct/maternal model gave the best results (Chapter 3 ). In both situations an influence of the piglet itself on the probability of farrowing survival was found. Pre-weaning survival can be described with a maternal/nurse sow model. The results of this model for the sire line were difficult to interpret. The variance components for both animal effects were very high and their genetic covariance was highly negative, resulting in relatively high heritabilities and a strong negative correlation between them. On the basis of the log-likelihood ratios, all other models fitted the data equally well, except for the most complicated (direct/maternal/nurse sow) model in the sire line, which fitted the data better.

In conclusion, a model with direct piglet and nurse sow animal effects described the individual piglet survival data quite well and is easy to interpret. This shows that the vitality of the piglet in addition to the mothering ability of its nursing sow is important for its survival.

To determine the predictive value of EBVs, a simpler approach was followed in Chapter 4. The analyses presented in Chapter 3 resulted in low heritabilities. Low heritabilities are used as an argument for not selecting for a trait (Kerr and Cameron, 1995; Roehe and Kalm, 2000). In Chapter 4 breeding values for piglet survival were estimated for future litters of gestating sows. The breeding values were estimated with a model where the only important animal effect for piglet survival was the genotype of the 
piglet itself. The anticipated litters were divided into low and high groups on the basis of their pedigree index. After birth, the piglets of these litters were individually identified and realized survival was recorded and analyzed. The predictive value of this approach was good: survival in the high pedigree index animals was significantly higher than survival in the low pedigree index animals. The regression coefficient of realized survival on pedigree index was not significantly different from 1.0 , indicating that the pedigree index is a good predictor of actual survival. Thus, selection on survival will work, despite the low heritability on a piglet basis.

In Chapter 5 performance traits were analyzed in relation to survival traits. Genetic correlations suggested that single trait selection for survival will lead to animals with a higher feed intake, higher growth, higher protein-, and in particular, a higher lipid deposition. The genetic correlation between piglet survival and ultrasonically measured back fat, analyzed with a model with only a direct animal effect, was high $(+0.5)$. The genetic correlation between the direct effect of pre-weaning survival and back fat, analyzed with a direct-nurse sow model, was also +0.5 . This indicates that there is a conflict between simultaneous improvement of survival and carcass quality.

\subsection{Farrowing and pre-weaning survival}

The current work emphasizes piglet survival, defined as survival of the piglet from late gestation to weaning. In most research a distinction is made between farrowing survival (stillbirth) and pre-weaning survival.

The definition used for stillbirth in the current project was "dead and wet behind the sow', and included piglets that died just before, during, or within a few hours after farrowing. Although the latter category was included in the stillbirth definition, those piglets were actually live-born, because they experienced respiratory activity before death (Randall and Penny, 1967; Randall, 1972). Sow related traits, that are important for farrowing survival, are total duration of farrowing and expulsion time per piglet (Randall, 1972; Zaleski and Hacker, 1993). Characteristics important for the piglet are length and strength of the umbilical cord, and amount of body reserves (Randall, 1989). Pre-weaning survival was defined as the number of piglets surviving to weaning expressed as a percentage of littermates live-born. Relevant sow components of pre-weaning survival are behavior of the sow, udder quality and colostrum quality and quantity. Important components for the piglet are energy reserves in the first hours after farrowing, colostrum 
intake, and mobility. On the basis of their different underlying biological factors, farrowing survival and pre-weaning survival should be treated as separate traits, since it is expected that different genes will be involved. However, selection on piglet survival as a whole gave improvements in both traits on both farms (Chapter 4). Selection on piglet survival as a whole, therefore, appeared to influence both farrowing survival and preweaning survival. The genetic correlation between the two traits was $0.14 \pm 0.13$ before correction for litter traits (Chapter 2) and $0.28 \pm 0.13$ after correction (result not shown), indicating that selection for farrowing survival alone is not expected to greatly improve pre-weaning survival. Index selection is theoretically more powerful than selection for a combined trait, especially if economic values or heritabilities of the involved traits differ. However, in the current situation the economic values for both survival traits are very similar and heritabilities are not very different either.

In conclusion, selection on piglet survival will improve both farrowing- and preweaning survival and is appealing in its simplicity. The objective is to produce piglets that do not die whenever, until the moment of slaughter has arrived.

\subsection{Is mothering ability genetically important and how should it be approached?}

Mothering ability is an important trait for piglet survival. We were aware of this, both at the start and during the current project. However, emphasis tended to be drawn towards the genotype of the piglet. A complicating factor in the analysis of mothering ability is the non-random nature of cross-fostering as shown in Table 2 of Chapter 3. Crossfostered piglets are substantially smaller, but survive just as well as their non-crossfostered litter mates. Attempts to estimate direct, maternal and nurse sow effects in a simultaneous analysis resulted in quite consistent parameters in which survival variances were relatively evenly distributed over these three animal effects. The contribution of maternal and nurse sow effects were more or less similar and resulted in low heritabilities (Chapter 3). On a litter basis, heritability of the maternal effect was 0.06 (Chapter 2). A similar approach for mothering ability on a litter-nursed basis (see Figure 1) yielded a heritability of $0.084 \pm 0.008$. This heritability increased to 0.14 after correction for the genetic quality of the piglets (results not shown).

However, the non-random nature of cross-fostering presents problems for an unbiased analysis. Two examples are drawn from a review of Le Dividich (1999). The first relates 
to selective teeth clipping of the heaviest piglets in a litter in order to increase competitiveness of the smaller piglets. Teeth clipping did increase survival of the smaller piglets, but decreased survival of the other piglets. It can be considered as preferential treatment of these piglets and will therefore bias estimation of genetic parameters. The second example concerns the spreading of disease as a result of cross-fostering. A crossfostered piglet, that introduces a disease in his new litter, is less at risk (if it drank colostrum with its biological mother) than its new litter mates. This phenomenon will decrease the average survival of non-cross-fostered piglets and will tempt farmers to increase cross-fostering.

An alternative for selection on mothering ability is to select directly on its underlying traits. This is of interest if the underlying traits have a higher heritability than mothering ability itself. Important underlying traits are milk quantity and quality, number and quality of teats, quality of the attachment of the udder, especially the rear udder, and maternal behavior (e.g. Rydhmer, 2000). We did some work in this area (unpublished) and found a heritability of $0.04 \pm 0.01$ for aggression, with a repeatability of $0.42 \pm 0.01$ For crushing of piglets as a maternal (dam) trait, the heritability was $0.04 \pm 0.01$ and repeatability $0.07 \pm 0.01$. Aggression and crushing account for much of the death loss which farmers find so irritating. Aziz et al. (1995) estimated a heritability for the quality of the rear udder attachment of 0.19 . Assessment of mothering ability in field data is risky and assessment of all underlying traits is labour-intensive. Nevertheless, selection for improved nurse sow effect, as part of the piglet survival approach in Chapter 3, will help to increase mothering ability. Good recording of one or two specific problem traits, such as rear udder quality, will help to speed up genetic improvement.

If heritability of litter size $(0.10)$ is taken as a reference value, heritability of mothering ability is good (between 0.08 and 0.14 ). Possible complications involved in a selection strategy for increased mothering ability could include correction for the effects of crossfostering and correction for genetic differences in piglet vitality. It would be worthwhile to create an experimental situation in which all piglets are removed from sows and then randomly redistributed, creating evenly sized litters. Survival and gain to weaning should be recorded. The resulting data set will create the opportunity to correctly and simultaneously estimate the genetic contributions of piglet and nurse sow. 


\subsection{Birth weight and survival}

The literature on piglet survival has for quite some time and in different parts of the world recognized the (phenotypic) importance of higher birth weight for survival (Bereskin, 1973; Fahmy, 1978; Fireman, 1997; Daza 1999). Gradually, a tendency has developed to interpret this phenotypic correlation as a genetic correlation and to replace selection for increased piglet survival by a selection strategy for increased birth weight. Roehe (1999) and Kaufmann (2000) mention this assumed correlation to stress the importance of birth weight.

The phenotypic correlation between individual birth weight and individual survival, without correction for birth weight, was 0.34 , and the genetic correlation was 0.00 (in the present study). On a litter basis these figures were 0.27 and 0.11 , respectively. Siewerdt and Cardellino (1996) reported a negative genetic correlation between birth weight and survival of -0.20 . Grandinson et al. (2000) found a genetic correlation of +0.25 between total number dead and mean birth weight. These values cast some doubt on the approach of increasing survival through a genetic increase in birth weight. In Chapter 4 different forms of selection were analyzed. Selection for birth weight $\left(E B V_{-} b w\right)$ did not increase survival. If anything, pre-weaning survival decreased on both farms. Simulated selection for survival ( $E B V_{-} s u r v$ ) increased pre-weaning survival significantly, but did not change birth weight.

Data illustrating the relationship between pre-weaning survival and birth weight in various situations are plotted in Figure 2. Individual refers to a reference line, which is the 'normal' relation between individual birth weight and individual pre-weaning survival, as found in the data sets used for the analyses here. Lee and Haley (1995) showed that piglets from full Meishan litters survive almost as well as from full Large White litters, despite the fact that Meishan litter size was four piglets higher, and Meishan average birth weight was some $450 \mathrm{~g}$ lower. Obese in Figure 2 represents data from the obese and lean lines of Mersmann et al. (1984). Selection lines represent birth weight and survival data from Kerr and Cameron (1995). Mice refers to survival and birth weight data extracted from Rauw et al. (1999), in which birth weight of mice pups was multiplied by 1000 .

If the genetic relationship between survival and birth weight is very good it would be expected that genetically different groups, which differ in birth weight, would also differ in survival. This is not the case, as in some situations the birth weight-survival 
relationship is opposite to that expected. The line closest to the expected curve is that of the selection/control line in the mice selection experiment of Rauw et al. (1999).

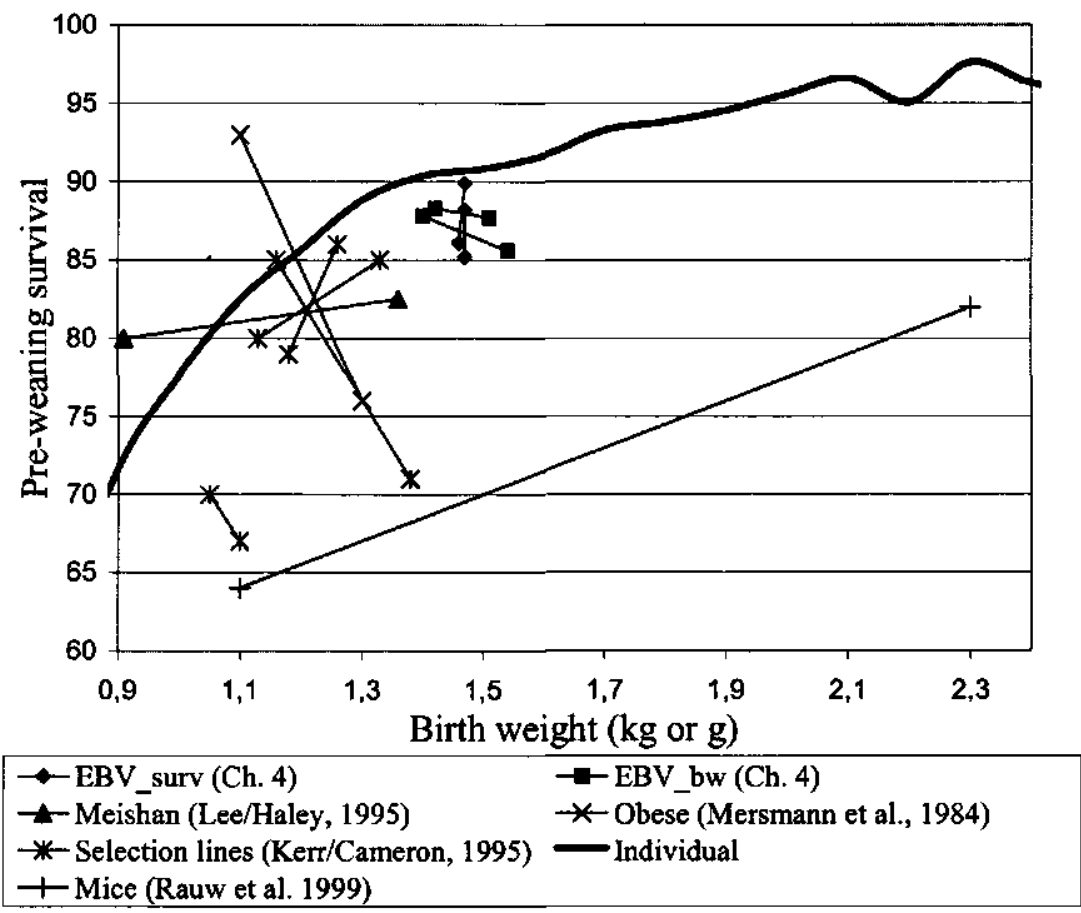

Figure 2: Relationship between birth weight and pre-weaning survival of piglets and mice pups. The bold line represents an individual weight-survival curve of piglets, and symbols group averages in different experiments. For further explanation see text.

It is unlikely that direct selection for birth weight or increased birth weight as a correlated response to selection for other traits will increase survival. Speculation on the nature of the negative genetic correlation between birth weight and survival could be a third factor. Selection for litter size, for example, will decrease birth weight $\left(r_{g}=-0.49\right)$ and increase pre-weaning mortality $\left(r_{g}=-0.45\right)$ (Chapter 2, Table 4), giving rise to the idea that selection for increased birth weight will increase pre-weaning survival, while the direct correlation between the two is only 0.11 . Another 'third factor' could be body fat. Body fat influences both survival and birth weight. The maternal genetic correlation between back fat and birth weight is negative $(-0.25)$ and the direct (piglet) correlation 
between backfat and survival is positive. This might explain the negative genetic correlation between birth weight and piglet survival.

Perhaps it is not average birth weight, but variation in birth weight that causes the problems with small piglets. In Chapters 2 and 4 clear associations between variation in birth weight and survival were found.

It is possible that selection for survival will decrease variation on the high side of the weight distribution. Weight and/or development of the heaviest piglets influence the onset of farrowing (Stryker and Dziuk, 1975). Van der Lende and De Jager (1991) took an interesting approach. This approach estimates whether or not possible runts or giants are present in a litter. Their technique is based on different types of outlier analysis and estimates whether the one or two lightest and heaviest piglets of a liter are part of the normal distribution of this litter. One of the possible outcomes is a left-hand litter, which reflects a second distribution on the low birth weight side of the distribution.

If the hypothesis holds that variation on the high side of the distribution causes part of

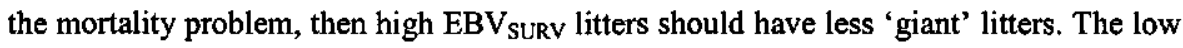
and high EBV groups from Chapter 4 were analyzed using this approach and results are given in Table 2. Results are in good agreement with Van der Lende and De Jager (1991), but no real difference in distribution was found between low and high EBV groups. This indicates that selection for survival will not lead to a reduction in the occurrence of runts or giants. However, there were only 9 incidences of 'giant' litters on both farms. The analysis was repeated for a second multiplier (Table 3) and again few differences between low and high EBV_survival were found. Therefore, it is unlikely that selection for higher survival will profoundly influence the distribution of birth weights within a litter. The reduction in variation in birth weight is apparently not due to a the decrease or loss of a second distribution.

The marginal genetic regression of litter weight on litter size is around $1.0 \mathrm{~kg}$ per piglet born (from this study and from Kerr and Cameron, 1995), indicating that an increase in litter size will gradually decrease average birth weight. The genetic correlation between litter size and litter weight is high ( 0.6 from Rothschild and Bidanel, 1995; 0.5 from Roehe, 1999). In mice, genetic gain in litter size was slightly higher in a divergent selection experiment on litter weight than in a line selected on litter size (Fernandez, 1998). It might be a good idea to use information on litter weight in the selection for litter 
size. It will help to increase litter weight and the correlated negative response in average birth weight will be reduced.

Table 2: Low and high EBV $V_{\text {SURV }}$ litters, classified as normal litters, litters with runts, or litters with giants, in two lines (data from Chapter 4).

\begin{tabular}{lcccc|c}
\hline & \multicolumn{2}{c}{ Dam line } & \multicolumn{2}{c|}{ Sire line } & \\
\cline { 2 - 6 } Litter type & Low EBV & High EBV & Low EBV & High EBV & Reference $^{\mathrm{a}}$ \\
\hline \#1 or 2 runts & 17 & 16 & 12 & 24 & \\
\#left-hand litters & 13 & 11 & 31 & 26 & \\
\#normal litters & 69 & 75 & 131 & 123 & \\
\#right-hand litters & 3 & 5 & 5 & 5 & \\
\#1 or 2 giants & 4 & 1 & 1 & 3 & \\
Total litters & 106 & 108 & 180 & 181 & 819 \\
& & & & & \\
\% 1 or 2 runts & 16.0 & 14.8 & 6.7 & 13.3 & 21.0 \\
\% left-hand litters & 12.3 & 10.2 & 17.2 & 14.4 & 10.3 \\
\% normal litters & 65.1 & 69.4 & 72.8 & 68.0 & 64.2 \\
\% right-hand litters & 2.8 & 4.6 & 2.8 & 2.8 & 1.7 \\
\% 1 or 2 giants & 3.8 & 0.9 & 0.6 & 1.7 & 2.8 \\
\hline
\end{tabular}

${ }^{\mathrm{a}}$ Van der Lende and De Jager (1991)

Table 3: Low and high $E B V_{S U R V}$ litters, classified as normal litters, litters with runts, or litters with giants, in the same dam line as Table 4, but on a different farm.

\begin{tabular}{lcc}
\hline \multirow{2}{*}{ Litter type } & \multicolumn{2}{c}{ Dam line } \\
\cline { 2 - 3 } & Low EBV & High EBV \\
\hline Total litters & 1049 & 1127 \\
\%1 or 2 runts & 15.8 & 15.2 \\
\%left-hand litters & 13.3 & 11.9 \\
\%normal litters & 67.2 & 68.9 \\
\%right-hand litters & 1.6 & 1.7 \\
\%>1 or 2 giants & 2.1 & 2.3 \\
\hline
\end{tabular}


In conclusion, we have to accept that, with an increase in litter size, average birth weight will decrease. Selection for increased average birth weight is not an option. Selection for increased litter weight could, in order to maintain selection pressure on litter size and to achieve an acceptable birth weight. However, piglet survival seems to have more to do with body reserves and possibly crowding of the piglets in the uterus, than with birth weight per se.

\subsection{Survival in Large White and Meishan breeds}

It is difficult not to notice some of the resemblances between high-survival groups of pigs and the Meishan breed in terms of piglet survival. The Meishan breed is considered to have a high prolificacy and high levels of body fat. It has been shown that it is possible to increase survival at a given birth weight, especially at lower birth weights (Chapter 4). Lee and Haley (1995) reported a $10 \%$ higher survival in Meishans at a given birth weight. Herpin and Hulin (2000) provided at least part of the explanation for this increase in survival. They studied thermo-regulation of Meishan and Large White*Pietrain newborn piglets and concluded that in the European piglets the summit metabolic rate started to decrease below a weight of $1125 \mathrm{~g}$, indicating that below that weight problems in maintaining body temperature increased with decreasing environmental temperatures. In Meishan piglets no such a breakpoint was found. Even light Meishan piglets were able to maintain body temperature. Slee and Stott (1986) reported a heritability of 0.17 for cold resistance in divergently selected lambs. Considering these results, selection for cold resistance may also be effective in pigs.

In the experiments of Lee and Haley (1995) average birth weight was $1306 \mathrm{~g}$ for the European and only $972 \mathrm{~g}$ for the Meishan piglets. Leenhouwers (2001a; 2001b) found higher liver and muscle glycogen levels and a higher body fat percentage in groups of piglets with a high genetic merit for survival. Mersmann (1974) suggests that an increase in body reserves will help to increase survival, through improved thermo-regulation and through availability of direct usable energy. In Chapter 5 a high genetic correlation between back fat and survival was found, indicating that selection for survival will result in an increase in body fat.

Lee and Haley (1995) reported lower variation in the birth weight of Meishan litters compared with Large White litters. Wilson et al. (1998) calculated the ratio between birth weight of the piglet and its individual placenta and found higher ratios for Meishan piglets, indicating more efficient placentas. Litters with a high genetic merit for survival 
showed a non-significant $(\mathrm{p}=0.08)$ increase in this ratio, but a significant reduction in within-litter variation in placental weight, suggesting more uniformity in placentation (Leenhouwers, 2001a). In Chapters 2 and 4 an increase in genetic merit for survival reduced variation in birth weight.

\subsection{Optimizing selection on performance traits}

Genetic correlations of the direct and nurse sow effects of pre-weaning survival with performance traits are, in general, rather unfavorable (Chapter 5). In particular, the genetic correlation between the direct effect of the piglet on survival and back fat at 130 $\mathrm{kg}$ is high (+0.51). An attempt was made to quantify the effect of different selection strategies on performance traits. Selection indices were used, starting with the situation of a limited breeding goal, in which correlated responses were ignored. Appraisal of the strategies was made using the trait 'Economic gain', calculated on the basis of all relevant traits and their proper economic values. For example, if the breeding goal was 'increased gain and decreased backfat', and measurements were taken on the same traits, economic gain was calculated including the effects on feed intake and survival, even if they were not included in the breeding goal. The direct effect of the piglet on pre-weaning survival will be addressed as 'vitality', the nurse sow effect as 'mothering ability'. Selection was simulated for a population of 250 sows and 50 boars with 8 offspring of each sex per year, and information on own performance and breeding values of parents available for all animals. Genetic response was simulated for single stage selection with discrete generations. Selection decisions were made after the performance test, with no selection on gilts and a top $10 \%$ selection of boars.

Response to BLUP selection was predicted using the deterministic simulation program MSSEL (Rutten et al., 2000). The current version of the program does not allow the use of a second-generation effect, such as maternal or nurse sow effect. The results given assume a direct model for piglet survival and birth weight. The economic value for $1 \mathrm{~mm}$ back fat, measured at $130 \mathrm{~kg}$ live weight, was assumed to be 1.50 (derived in a manner similar to De Vries, 1989). One gram of gain in the phase $29-130 \mathrm{~kg}$ was valued at 0.10 if feed intake was taken into account separately, or 0.005 if the value of feed intake was assumed to be integrated into the value of gain. Feed intake itself was measured from $75-130 \mathrm{~kg}$ and was valued at - $0.018 \mathrm{per} \mathrm{g} / \mathrm{d}$. Piglet survival was valued at $\quad 0.60$ per \% survival (costprice reduction per slaughterpig). Heritabilities and correlations between pre-weaning survival, birth weight and performance traits were 
taken from Chapter 5 and, where necessary, supplemented with similarly calculated correlations between performance traits. Economic gain was based on the weighted sum of direct and correlated economic responses in the full breeding goal $\left(\mathrm{H}^{*}\right)$. Gain, backfat, feed intake and survival were all taken to be economically important traits, even if they are, under the assumption of zero economic values, not considered in the actual breeding goal $(\mathrm{H})$.

Simulations were performed for different selection strategies and results are given in Table 4. The first strategy was named Simple finishing and depicted the situation in which selection was performed with test gain and backfat both in the breeding goal and in the index (B). Expected genetic gain (per generation) was $21 \mathrm{~g}$ for test gain and $-0.25 \mathrm{~mm}$ for backfat. Correlated responses were $+34 \mathrm{~g} / \mathrm{d}$ for feed intake and $-0.5 \%$ for vitality. Profit for this strategy was calculated to be 1.57 per pig per generation, using all genetic responses and the proper economic values. Strategy 2 Recognizing feed intake had feed intake explicitly in the breeding goal, but not in the index. This strategy was superior to Simple finishing in its more precise definition of the breeding goal. Economic gain dropped to 1.05 , resulting from a larger negative response in vitality. Efficient finishing included measurements on feed intake in the selection index. As a result genetic gain in feed intake improved. Economic gain increased to 1.79. Recognizing survival honored the economic value of survival. Compared with the previous strategy, the expected genetic response in feed intake, vitality, and economic gain increased, but the response in back fat gain was, without measuring extra traits, reduced to zero. Maximum economic gain was, obviously, reached with all traits in the breeding goal and all traits in the selection index (Measuring it all). Since exact recording of cross-fostering and mortality is labor intensive, the consequences of dropping this information were evaluated in the next strategy and economic gain decreased by 0.49 . Subsequently, not recording feed intake gave an extra loss of 1.00 in economic gain. The penultimate strategy was, again, measurement of gain and backfat, but now incorporating full knowledge of all correlations and the complete aggregate genotype. Economic gain was only a little higher compared to that with the strategy in which these relationships were assumed unknown (Simple finishing), but with substantially different expected genetic responses per trait.

All simulated strategies included selection for lean gain and resulted in an increase in birth weight. It is not uncommon to find an increase in birth weight in animals selected 
for lean gain. Mersmann et al. (1984) described differences between genetically lean and obese lines of pigs, and reported birth weights of $1.1 \mathrm{~kg}$ for piglets of the obese line, and $1.3 \mathrm{~kg}$ for piglets of the lean line. This particular piece of evidence for the effect of genetic leanness on birth weight is quite strong, since litter size was 7.8 for the obese line and 10.7 for the lean. This proves that the decrease in birth weight was not the correlated response of an increase in litter size. Gaughan et al. (1995) looked at differences between sows with different phenotypes for backfat and found $-210 \mathrm{~g}$ difference in birth weight between the high and low backfat groups of sows (difference $+6 \mathrm{~mm}$ backfat), i.e. fatter sows had lower birth weights. In contrast, Kerr and Cameron (1995) could not find significant differences in birth weight in their lean gaịn selection lines.

The strategy Simple finishing resulted in a loss of survival of $0.5 \%$ per generation. Mersmann et al. (1984) reported a large difference in survival between their obese and lean lines ( $93 \%$ versus $76 \%$, uncorrected for birth weight). The phenotypic data of Gaughan et al. (1995) showed a non-significant $1.5 \%$ advantage in total survival for the fat group of sows, again uncorrected for birth weight. The findings of McKay (1993) are possibly in very good agreement with the current findings for Simple finishing. McKay concluded that: 'It is clear that the selection practiced in the Yorkshire (eight generations) and Hampshire (seven generations) breeds has resulted in increased pre-weaning piglet deaths due to the sow.' So, he suggests that lack of mothering ability is the main problem. Selection was practiced on an index of back fat and average daily gain.

The predicted differences between selection strategies in the present study were large. Piglet survival varied from -1.6 to $+3.0 \%$ between strategies. Kerr and Cameron (1995) reported a $5 \%$ higher mortality in their high lean growth (ad libitum) selection line compared with their low one; on a scale feeding regime this difference was $14 \%$. The significance of the differences was not explicitly given; estimates of the differences on the logistic scale were $-0.4 \pm 0.4$ and $-0.9 \pm 0.4$. Selection was practiced for 5 generations. On average their mortality increased by $2 \%$ per generation $((14 \%+5 \%) / 2$ in 5 generations), which is in good agreement with the simulation results given here. Current analyses were performed in a sire line. Heritability for survival was relatively high $(0.09)$, in the sire line, compared with the sow line (Chapter 3). An explanation is, that through selection gradually minimum body fat levels are approached in sire lines, below which problems may arise in survival. 
A key factor in the simulation results is feed intake. Feed intake seems to have a biological optimum, since it has a positive genetic correlation with vitality and a negative correlation with mothering ability. This last correlation is interesting, because an important limiting factor for further increase of commercial pork production seems to be feed intake during lactation. If feed intake during lactation is too low, the interval from weaning to oestrus may be increased (Prunier and Quesnel, 2000). A suggested strategy for realizing a reduction in interval from weaning to oestrus is selection for increased feed intake (Eissen, 2000). Selection for increased feed intake, however, could backfire in terms of mothering ability. Feed intake in the current analyses was measured in the heavy weight phase of testing. The correlation of mothering ability with estimated protein deposition in the heavy weight phase of the test was highly negative, whilst with lipid deposition it was around zero. A sow with a good mothering ability could therefore be an early maturing animal with a somewhat reduced appetite at heavier finishing weights.

The correlation between vitality and mothering ability was moderately negative (Chapter 5: $-0.31 \pm 0.22$ ). Speculation on the biological nature of this correlation could be made in relation to selfishness. A sow with a low mothering ability will utilise nutrients from feed for her own recovery and is therefore better equipped for her own survival. The question is then whether the mechanisms causing this increased survival will also operate in a comparable manner in young piglets. The population in which the parameters were estimated appeared to compensate for an increase or decrease in vitality with a respective decrease or increase in mothering ability. In most pig breeding programs, specialization of sire and dam lines has been applied. Use of this phenomenon makes it possible to circumvent this negative correlation; "selfish" sire lines with "mothering" dam lines.

It is concluded that the mostly negative response in survival to selection for lean growth can be reversed with a well-designed selection program. However, genetic progress in back fat will then be reduced to around zero.

\subsection{Optimizing selection on reproduction traits}

Selection on reproduction traits was simulated using the same breeding scheme assumptions as for finishing traits. A discrepancy with reality was that performance in litter traits was assumed to be measurable on boars. This is debatable, as is the 
assumption that no offspring and no sibs were tested and that no selection in gilts was practiced. Assuming the availability of information on boars, however, mimics the more realistic situation of progeny recording outside the nucleus. All strategies were evaluated with the same assumptions and emphasis was placed on the possible effects of reproduction traits selection on piglet survival, rather than on the expected effects of different information structures. The value for a live-born piglet was assumed to be 4.50 and per percentage survival, both farrowing and pre-weaning, 0.60 . Selection index theory was applied with the exception of 'Sustainable' and 'Max. sust. selection', in which the economic weight of survival was subjectively doubled in the breeding goal (desired gains approach). Economic gain, however, was calculated using the defined economic values, and comparisons between strategies on the basis of economic gain are valid.

Selection for litter size (total born) only (Table 5: 'Litter size') resulted in a marked increase in litter size ( 0.25 piglet per generation) and a small increase in farrowing survival, the net result still being an increase in \#stillborn per litter (scale effect). Preweaning survival decreased. A selection strategy aiming only at survival ('Survival') did increase survival and decrease litter size, the net result being positive, i.e. more piglets weaned per litter. If both approaches were combined ('Economy'), expected trends in litter size and farrowing survival were positive, but the trend in pre-weaning survival was negative. Use of information on birth weight, variation in birth weight and gestation length ('Maximum Economy') increased gain in the index by some $15 \%$, but did not result in a positive trend in pre-weaning survival. Subsequently, the value for survival was arbitrarily doubled ('Sustainable'), which resulted in a situation of desirable trends for litter size, farrowing- and pre-weaning survival both in absolute and relative terms. Use of extra available information ('Maximum Sustainable') resulted in economic gain (using the original economic values!) to a level lower than the maximal economic approach but with favorable trends in all traits, which is to be expected since selection index theory maximises economic response. The subjective doubling of the economic value results therefore in a (only slightly) lower economic response. Selection for increased birth weight ('Birth weight') is a very effective way of decreasing littersize; it increases pre-weaning survival somewhat, but it decreases farrowing survival. As a consequence, adding birth weight selection to litter size selection ('LS/BW') resulted in an increase in birth weight, while the other traits remain constant. Birth weight does not 
have an economic value of its own; it was subjectively entered in the index on a 50/50 (genetic std) basis with litter size.

According to the literature review of Rothschild and Bidanel (1998), the genetic correlation between litter size and pre-weaning survival is only slightly negative $(-0.11)$. However, the selection experiment on litter size of Johnson et al (1999) resulted in a 0.22 piglets/litter per generation increase in litter size, of which 0.11 were stillborn. No trend in \#weaned/litter was found, indicating a negative response from selection for litter size on farrowing and pre-weaning survival. Lund et al. (2000) found a genetic correlation of -0.39 between litter size and pre-weaning survival, which is in very good agreement with the current estimate of -0.45 (Chapter 2 ). Size of the correlation can very well depend on litter size. With increasing litter size, crowding of piglets in the uterus will increase. This may harm development of the piglets and have negative consequences on survival. The definition of pre-weaning survival may be another explanation for the discrepancy between our results and the average literature values. If pre-weaning survival is defined in terms of mothering ability, i.e. after cross-fostering, the correlation with litter size will be much lower than with the definition in our studies. This is also true for the definition of Lund et al. (2000), in which pre-weaning survival was calculated as a fraction of the number of live-born piglets in a litter, regardless of whether piglets were cross-fostered or not. Rauw et al. (1999) reported results of a selection experiment on litter size in mice, where the difference between the selection and the control population after 101 generations was 10 pups. Pup development in high litter size line litters was $25 \%$ lower than in control line litters, and pre-weaning mortality was considerably higher in the high litter size line (36\%) than in the control line (18\%). This corresponds, assuming linearity, to a $1.8 \%$ increase in pre-weaning mortality per pup increase in litter size. From Table 5 , 'Litter size selection' it can be calculated that the expected increase in pre-weaning mortality in pigs is $1.88 \%$ per extra piglet. Similarly, from the results of Rauw et al. (1999) the average birth weight of pups can be derived as $2.29 \mathrm{~g}$ in the control line and $1.07 \mathrm{~g}(=47 \%$ of control) in the high litter size line. Table 5 indicates that an increase in litter size of one piglet will result in a $72 \mathrm{-g}$ decrease in average birth weight. As current birth weight is around $1450 \mathrm{~g}$, genetic doubling of litter size will thus decrease birth weight by some $50 \%$. This predicted result in pigs is remarkably similar to the result obtained in mice. If this also holds for other traits, the pig industry might expect some 3.7 
$\%$ increase in adult weight and mature daily feed intake from a genetic improvement of litter size of 1 piglet.

Genetic parameter estimation and within-line experiments suggest that it is possible to change current commercial lines to ones which will resemble the Meishan breed in a number of commercially important traits. Given a difference between Meishan and Large White in litter size of +4 piglets, in average birth weight of $-400 \mathrm{~g}$, and in variation in birth weight of $-60 \mathrm{~g}$ (Lee and Haley, 1995), and using the 'Economy' selection strategy, it would take some 15 generations to change a Large White into a Meishan for these three traits. Other information from Meishan studies might also be relevant for direct use.

\subsection{General conclusions}

1. Selection for increased piglet survival is necessary and possible. This selection should address piglet vitality, the maternal effect and mothering ability. It was not possible to fit a model with these three genetic effects for piglet survival. For pre-weaning survival a maternal-nurse sow model gave the best fit for both lines. Well-structured data sets with a high degree of crossfostering are necessary for a good separation of the genetic effects.

2. A straightforward selection approach, with only the direct effect of piglet survival in the model, will result in visible differences in piglet survival in the desired direction. It seems likely that more precise genetic models will increase accuracy and expected genetic progress.

3. To genetically improve piglet survival, piglet survival should be observed. Selection on birth weight as an indirect way to improve piglet survival is not a good strategy. Differences between piglets in survival will be found in differences in body composition rather than in differences in birth weight. (Lack of) variation in birth weight is important for survival and it shows genetic variation. An indirect strategy to improve piglet survival could be to select for decreased variation in birth weight.

4. Emphasis in selection for reproduction traits can be changed in the direction of survival, without decreasing total economic gain. This will give a better-balanced genetic improvement, a lower trend for total number born and positive trends for survival traits.

5. The genetic correlation between piglet survival and backfat is moderately high (0.5): Simulations suggest a visible decrease in piglet survival resulting from selection aiming at lower levels of backfat. Knowledge of the genetic relations makes it 
possible to build an index, which will allow a more balanced genetic progress, with an increase in piglet survival, instead of a decrease.

\subsection{References}

Aziz, M.A., R. Roehe, and E. Kalm. 1995. Genetic and environmental factores associated with firmness of the mammary gland in sows using quasi-loglinear and linear models. Arch. Terz., Dummerstorf. 38:665-671.

Bereskin, B., C.E. Shelby, and D.F. Fox. 1973. Some factors affecting pig survival. J. Anim. Sci. 36:821-827.

Daza, A., J.N.B. Evangelista, and M.G. Gutierrez-Barquin. 1999. The effect of maternal and litter factors on piglet mortality rate. Ann Zootechn. 48:317-325.

De Vries, A.G. 1989. A model to estimate economic values of traits in pig breeding. Livest. Prod. Sci. 21:49-66.

Eissen, J. J., E. Kanis, and B. Kemp. 2000. Sow factors affecting voluntary feed intake during lactation. Livest. Prod. Sci. 64:1372-1378.

Fahmy, M. H., W. B. Holtmann, T. M. MacIntyre, and J. E. Moxley. 1978. Evaluation of piglet mortality in 28 two-breed crosses among eight breeds of pigs. Anim. Prod. 26: 277-285.

Fernandez, J., A. Moreno, J.P. Gutiérrez, B. Nieto, P. Piqueras, and C. Salgado. 1998. Direct and correlated respons for litter size and litter weight at birth in first parity in mice. Livest. Prod. Sci. 53:217-223.

Fireman, F.A.T., and F. Siewerdt, 1997. Efeito do peso ao nascer sobre a mortalidade de leit es do nascimento até 21 dias de idade. R. Bras. Zootec. 26:479-484.

Gaughan, J. B., R.D.A. Cameron, G. McL. Dryden, and M.J. Josey. 1995. Effect of selection for leanness on overall reproductive performance in Large White sows. Anim. Sci. 61:561-564.

Grandinson, K., L. Rydhmer, E. Strandberg, and M.S. Lund. 2000. Estimation of genetic parameters for mortality and causes of death in piglets. EAAP 2000, The Hague.

Johnson, R. K., M. K. Nielsen, and D. S. Casey. 1999. Responses in ovulation rate, embryonal survival, and litter traits to 14 generations of selection to increase litter size. J. Anim. Sci. 77:541-557.

Herpin, P., and J.C. Hulin. 2000. Effect of birth weight on thermoregulatory abilities of Chinese (Meishan) and European (Large $x$ Piétrain) newborn piglets. In: Proceedings 
of the 15th Symposium on Energy Metabolism of Animals;10-16 sept. 2000; Elsinore, DK. (in press).

Kaufmann, D., A. Hofer, J. P. Bidanel, and N. Künzi. 2000. Genetic parameters for individual birth and weaning weight and for litter size of Large White pigs. J. Anim. Breed. Genet. 117:121-128.

Kerr, J.C., and N.D. Cameron. 1995. Reproductive performance of pigs selected for components of efficient lean growth. Anim. Sci. 60:281-290.

Lee, G. J., and C.S. Haley. 1995. Comparative farrowing to weaning performance in Meishan and Large White pigs and their crosses. Anim. Sci. 60:269-280.

Le Dividich, J. 1999. A review - Neonatal and weaner pig: management to reduce variation.VIIth Biennial Conference Adelaide, South Australia 1999:135-155.

Leenhouwers, J.I. 2001 a. Late prenatal development in the pig in relation to genetic merit for piglet survival 1. Uterine, placental and fetal development (in preparation).

Leenhouwers, J.I. 2001 b. Late prenatal development in the pig in relation to genetic merit for piglet survival 2. Blood characteristics and glycogen reserves (in preparation).

Lund, M.S., M. Puonti, L. Rydhmer, and J. Jensen. 2000. Relationship between litter size, perinatal, and preweaning survival in Landrace pigs. EAAP 2000, The Hague.

McKay, R.M. 1993. Preweaning losses of piglets as a result of index selection for reduced backfat thickness and increased growth rate. Can. J. Anim. Sci. 73: 437-442.

Mersmann, H. J. 1974. Metabolic patterns in the neonatal swine. J. Anim. Sci. 38:10221030.

Mersmann, H. J., W.G. Pond, R.T. Stone, J.T. Yen, and R.N. Lindvall. 1984. Factors affecting growth and survival of neonatal genetically obese and lean swine: cross fostering experiments. Growth 48:209-220.

Prunier, A., and H. Quesnel. 2000. Nutritional influences on the hormonal control of reproduction in female pigs. Livest. Prod. Sci. 63:1-16.

Randall, G.C.B., Penny, R.H.C. 1967. Stillbirth in pigs: the possible role of anoxia. Vet. Rec. 81:359-361.

Randall, G.C.B. 1972. Observations on parturition in the sow. II. Factors influencing stillbirth and perinatal mortality. Vet. Rec. 90:183-186.

Randall, G.C.B. 1989. Form and development of the umbilical cord in pigs and their association with delivery of viable pigs. Am. J. Vet. Res. 50: 1512-1515 
Rauw, W.M., P. Luiting, R.G. Beilharz, M.W.A. Verstegen, and O. Vangen. 1999. Selection for litter size and its consequences for the allocation of feed resources: a concept and its implications illustrated by mice selection experiments. Livest. Prod. Sci. 60:329-342.

Rothschild, M.F. and J.P. Bidanel. 1998. Biology and genetics of reproduction. In: M.F. Rothschild and A. Ruvinsky (ed) Genetics of the pig. p 323. CAB International, Oxon, UK.

Roehe, R., 1999. Genetic determination of individual birth weight and its association with sow productivity traits using bayesian analyses. J. Anim. Sci. $77:$ 330-343.

Roehe, R., and E. Kalm. 2000. Estimation of genetic and environmental risk factors associated with pre-weaning mortality in piglets using generalized linear mixed models. Anim. Sci. 70:227-240.

Rutten, M.J.M., P. Bijma, and J.A.M. van Arendonk. 2000. Optimising selection response in a multi-stage pig selection scheme at fixed costs. EAAP 2000, The Hague.

Rydhmer, L. 2000 . Genetics of sow reproduction, including puberty, oestrus, pregnancy, farrowing and lactation. Livest. Prod. Sci. 66:1-12.

Siewerdt, F, and R. A.Cardellino. 1996. Genetic parameters of piglet mortality from birth to 21 days of age in the Landrace breed. Revta Soc. Bras. Zootéc. 25:902-909.

Slee, J. and A.W. Stott. 1986. Genetic selection for cold resistance in scottish blackface lambs. Anim. Prod. 43:397-404.

Stryker, J.L., and P.J. Dziuk. 1975. Effects of fetal decapitation on fetal development, parturition and lactation in pigs. J. Anim. Sci. 40:282-287.

Wilson, M.E., N.J. Biensen, C.R. Youngs, and S.P. Ford. 1998. Development of Meishan and Yorkshire littermate conceptuses in either a Meishan or Yorkshire uterine environment to day 90 of gestation and to term. Biol. of Reprod. 58:905-910.

Van Arendonk, J.A.M., C. van Rosmeulen, L.L.G. Janss, and E.F. Knol. 1996. Estimation of direct and maternal genetic (co)variances for survival within litters of piglets. Livest. Product. Sci. 46:163-171.

Van der Lende, T. and D. de Jager. 1991. Death risk and preweaning growth rate of piglets in relation to the within-litter weight distribution at birth. Livest. Prod. Sci. 28:73-84.

Zaleski, H.M., and R.R. Hacker. 1993. Variables related to the progress of parturition and probability of stillbirth in swine. Can. Vet. J. 34:109-113. 


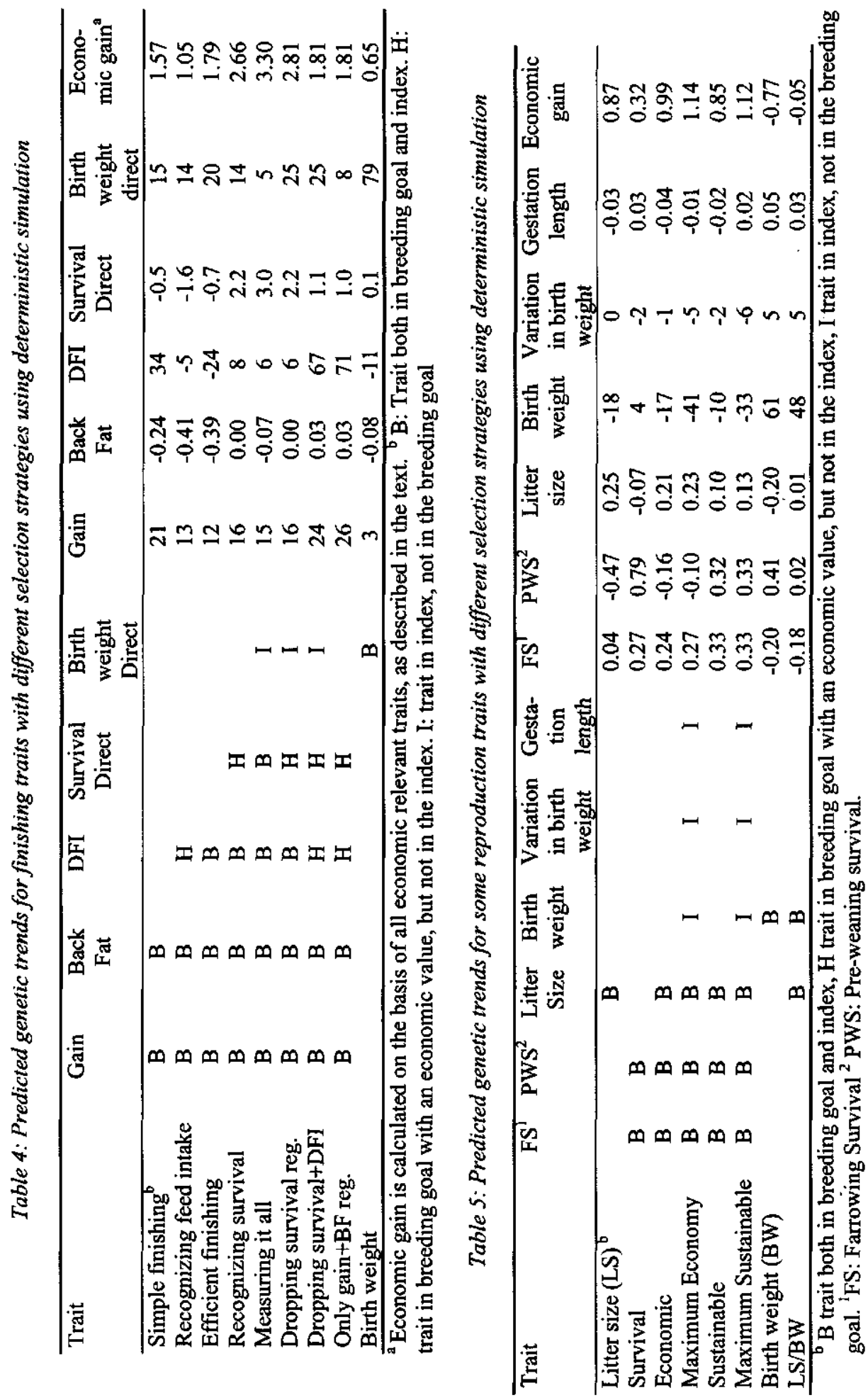


Piglet losses were classified as:

(g) died because the piglets were born in the gestating facilities (outside lots with insulated cabins) prior to the 109th day of gestation (when the sows enter the farrowing facilities);

McKay (1993) 


\section{Samenvatting}

De biggensterfte in Nederland is hoog. Gemiddeld overleeft bijna $20 \%$ van de biggen het traject van aanvang werpen tot spenen niet. Zo'n $7 \%$ van de biggen sterft tijdens of vlak voor de geboorte en $13 \%$ vanaf geboorte tot aan spenen. Nederland is hierin geen uitzondering. In de Verenigde Staten gaat vrijwel hetzelfde percentage van de biggen dood, zij het bij een lagere worpgrootte. De zeug wordt vaak gezien als de oorzaak. Doodliggen en zwakke, verkommerde biggen worden al snel aan karakter en (het tekort) melkproductie van de zeug geweten.

In dit proefschrift is gekeken naar het vermogen van de zeug om goede (vitale) biggen ter wereld te brengen, naar de kwaliteit van de big zelf en naar de moedereigenschappen van de zeug in abstracte zin, ofwel naar de erfelijke aspecten van baarmoeder, big en biest.

Een aantal bedrijven weegt sinds 1993, tegen vergoeding, alle geboren biggen, registreert het overleggen en de eventuele sterfte. In Tabel 1 zijn deze gegevens voor drie zeugen weergegeven. Bij de eerste zeug blijft 94 procent van de biggen in leven, bij de tweede $46 \%$ en bij de derde $95 \%$ (bigoverleving). Van de eerste en de derde zeug zijn vier biggen naar een andere zeug overgelegd. In beide gevallen hebben alle vier overgelegde biggen het overleefd. De derde is een eerste worpszeug. De worpmassa was $20.5 \mathrm{~kg}$, dit is een dikke $3 \mathrm{~kg}$ meer dan gebruikelijk. Toch wegen de 17 geboren biggen maar $1.21 \mathrm{~kg}$ ieder. Maar ze zijn wel bijzonder uniform. De standaardafwijking binnen de worp is erg laag: de lichtste big weegt 1040 gram en de zwaarste 1420 gram, waarbij de kleinste van 720 even buiten beschouwing gelaten is. De gegevens van 33.000 worpen zijn op deze manier verzameld en daarmee voor analyse beschikbaar.

\section{Kijken naar worpen van zeugen}

De gegevens boven de streep in Tabel 1 zijn als eerste geanalyseerd, dit zijn kenmerken die als worpgegevens zijn vastgelegd. De worpgrootte is vaak en door veel mensen geanalyseerd. De erfelijkheidsgraad komt gemiddeld uit op 0.10 met nauwelijks variatie naar boven of beneden. Dit betekent dat $10 \%$ van de verschillen tussen zeugen in het kenmerk worpgrootte een erfelijke achtergrond hebben. De huidige schatting van 0.09 
past daar aardig bij. Van worpgrootte is inmiddels bekend dat er door selectie van ouders met een goede aanleg voor worpgrootte een beduidende genetische vooruitgang gerealiseerd kan worden.

Het is hoopgevend dat de erfelijkheidsgraad voor worpoverleving op 0.06 uitkomt, niet eens zo heel ver van de 0.09 voor worpgrootte. Het niet doodgeboren worden en het overleven tijdens de lactatie vormen samen de worpoverleving. Deze twee componenten blijken ieder op zich ook erfelijk te zijn, met erfelijkheidsgraden van respectievelijk 0.05 en 0.06 .

Tabel 1: Drie zeugen met gegevens van hun biggen

\begin{tabular}{|c|c|c|c|c|c|c|c|c|}
\hline Zeug & & 5647837 & & 5738121 & & & 6134678 & \\
\hline Lijn/ras & & 020 & & 020 & & & 020 & \\
\hline Worpnummer & & 7 & & 7 & & & 1 & \\
\hline Jaar & & 1999 & & 1999 & & & 1999 & \\
\hline Worpgrootte & & 16 & & 16 & & & 17 & \\
\hline Worp massa & & 19,6 & & 21,0 & & & 20,5 & \\
\hline Geboortegewicht & & 1,23 & & 1,31 & & & 1,21 & \\
\hline Variatie & & 378 & & 354 & & & 178 & \\
\hline Drachtlengte & & 115 & & 111 & & & 114 & \\
\hline Worpsterfte & & $6 \%$ & & $56 \%$ & & & $5 \%$ & \\
\hline \multicolumn{9}{|l|}{ Biggen } \\
\hline 1 & & 0,60 & $\dagger$ & 0,70 & $\dagger$ & $\leftarrow$ & 0,71 & \\
\hline 2 & $\leftarrow$ & 0,60 & & 0,80 & $\dagger$ & & 1,03 & \\
\hline 3 & $\leftarrow$ & 0,66 & & 0,90 & $\dagger$ & & 1,04 & \\
\hline 4 & $\leftarrow$ & 0,96 & & 1,12 & $\dagger$ & & 1,07 & \\
\hline 5 & $\leftarrow$ & 1,04 & & 1,14 & $\dagger$ & & 1,11 & $\dagger$ \\
\hline 6 & & 1,16 & & 1,18 & & & 1,15 & \\
\hline 7 & & 1,22 & & 1,20 & & & 1,16 & \\
\hline 8 & & 1,26 & & 1,22 & $\dagger$ & & 1,17 & \\
\hline 9 & & 1,28 & & 1,26 & $\dagger$ & & 1,26 & \\
\hline 10 & & 1,30 & & 1,28 & $\dagger$ & & 1,27 & \\
\hline 11 & & 1,32 & & 1,62 & $\dagger$ & & 1,31 & \\
\hline 12 & & 1,44 & & 1,64 & & & 1,32 & \\
\hline 13 & & 1,58 & & 1,68 & & & 1,33 & \\
\hline 14 & & 1,58 & & 1,72 & & & 1,35 & \\
\hline 15 & & 1,76 & & 1,74 & & $\leftarrow$ & 1,35 & \\
\hline 16 & & 1,80 & & 1,84 & & $\leftarrow$ & 1,40 & \\
\hline 17 & & & & & & $\leftarrow$ & 1,42 & \\
\hline
\end{tabular}

$\dagger$ big doodgegaan tijdens de geboorte of tijdens het zogen

$\leftarrow$ big overgelegd naar een andere zeug

Kenmerken staan niet op zich, maar beïnvloeden elkaar soms positief, soms negatief en soms ook niet. Worpkenmerken die te maken hebben met overleving zijn: 1) 
geboortegewicht: zware biggen overleven beter, 2) worpgrootte: veel biggen, veel sterfte, 3) uniformiteit: veel variatie, veel problemen en 4) drachtlengte: het te vroeg geboren worden verlaagt de overlevingskans aanzienlijk. Probleem is dat deze vier factoren elkaar ook weer onderling beïnvloeden. Zo hebben grotere worpen gemiddeld een lager geboortegewicht, meer variatie en een kortere drachtlengte.

Het in kaart brengen van deze relaties vergroot het begrip en geeft de mogelijkheid om indirect te selecteren. $\mathrm{Er}$ is een duidelijk negatief genetisch verband tussen drachtlengte en percentage doodgeboren én drachtlengte is behoorlijk erfelijk. Het op peil houden van de drachtlengte bij een stijgende worpgrootte behoort daarmee tot de mogelijkheden en dit zal het percentage doodgeboren biggen in gunstige zin beïnvloeden

Op een vergelijkbare manier kan gekeken worden naar variatie in geboortegewicht. Het algemene gevoel is dat minder variatie betere overlevingskansen voor de biggen oplevert. Dit klopt in de huidige analyses, zowel in de stal als in de fokkerij. Ook de erfelijkheidsgraad van variatie in geboortegewicht $(0.07)$ is niet onaardig vanuit het oogpunt van selectie.

Geboortegewicht neemt een speciale plaats in. Overlevingskansen van zwaardere biggen zijn hoger dan van die van lichtere biggen, er is sprake van een positieve relatie. Deze positieve relatie heeft voor een deel te maken met concurrentie tussen biggen. Genetisch gezien is dit verband tussen geboortegewicht en overleving minder duidelijk. Immers ook bij een stijging van het gemiddelde geboortegewicht zullen de lichtste biggen nog steeds de concurrentie niet aan kunnen. Het klopt daarom niet wanneer door een vorm van correctie worpen eerst gelijk gemaakt worden voor worpgrootte, drachtlengte, geboortegewicht en variatie in geboortegewicht. Na deze correctie is het verband tussen geboortegewicht en overleving zelfs negatief. Dit geeft te denken. Selectie op betere overleving na correctie voor deze worpkenmerken kan dan zelfs leiden tot een daling van het geboortegewicht. Dit zal gebeuren bij correctie voor geboortegewicht in de fokwaardeschatting. Zonder correctie zal het geboortegewicht nauwelijks wijzigen.

De erfelijkheidsgraad van geboortegewicht als zeugkenmerk is vrij hoog (0.30) met opmerkelijk weinig invloed van de vader van de worp (0.02). Dit geeft aan dat het geboortegewicht van biggen vrijwel uitsluitend wordt bepaald door de zeug en nauwelijks door de biggen zelf. Bij rundvee is dit anders, daar heeft de stier een duidelijke invloed op het geboortegewicht van het kalf. 
In Figuur 1 is het verband tussen geboortegewicht en overleving weergegeven voor twee groepen biggen: een groep met een hoge verwachtingswaarde voor overleving en een groep met een lage verwachtingswaarde. De vorm van de curve is voor beide groepen hetzelfde, maar de groep met de hoge verwachtingswaarde is verschoven naar lagere geboortegewichten. Op hetzelfde gewicht overleven lichte biggen van de hoge groep aanzienlijk beter dan de lichte biggen van de lage groep.

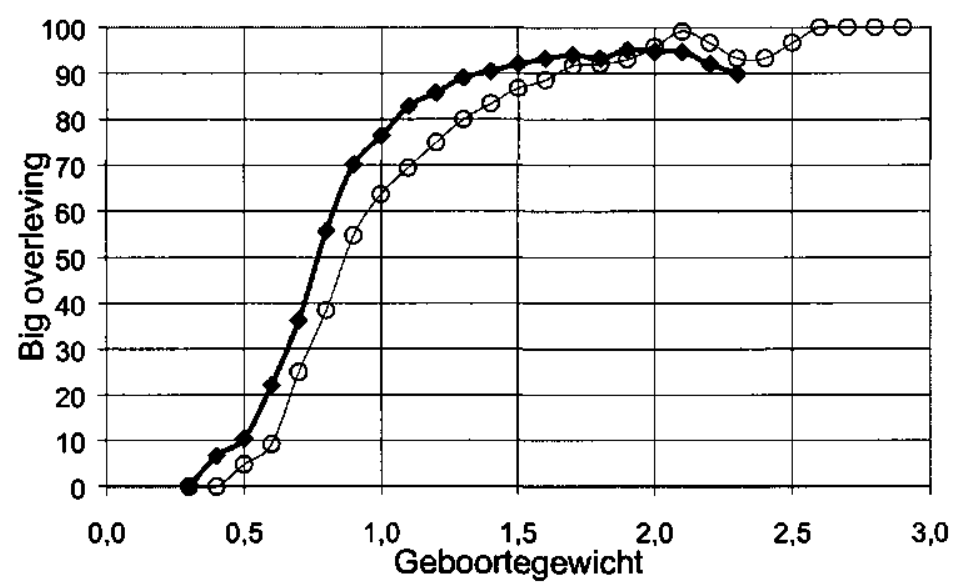

Figuur 1: Relatie tussen geboortegewicht en overleving in een groep biggen met een hoge verwachtingswaarde voor vitaliteit ( - ) en in een groep met een lage verwachtingswaarde (o-o).

\section{Kijken naar de biggen zelf}

Vervolgens zijn de gegevens aan de onderkant van de streep geanalyseerd, de biggen zelf. Het kenmerk waarnaar gekeken is, is de overleving tot en met spenen. Dit is een alles of niets kenmerk. Een big heeft het wel of juist niet overleefd. Een beetje overleven is er niet bij. Het gevolg is dat toeval, of error in statistische termen, een grote rol speelt. De erfelijkheidsgraden die hierbij geschat werden zijn laag, vooral door dit fenomeen. Wanneer gekeken wordt naar de hoeveelheid erfelijke variatie blijkt dit vrij aanzienlijk te zijn en goed overeen te komen met de resultaten van de schattingen op worpniveau. De aardigheid van de analyses op bigniveau is het uiteenrafelen van de genetische effecten. 
Het overleggen van biggen gebeurt niet willekeurig. Overgelegde biggen zijn gemiddeld lichter dan niet overgelegde biggen. Overleggen gebeurt om de kans op overleven van alle levend geboren biggen te vergroten. Lichte biggen zullen naar zeugen gaan waarvan verwacht wordt dat de zeug de big een betere kans geeft dan de biologische moeder. Een heel goede zeug, met een goede staat van dienst of met een mooi uier, loopt het risico dat ze vooral kleine zwakke biggen krijgt waarvan er betrekkelijk veel dood gaan. Ze wordt dan, ten onrechte, gestraft in haar fokwaarde voor grootbrengend vermogen.

In de analyses voor de overlevingskenmerken zijn daarom naast het effect van geboortegewicht, ook de genetische aanleg voor bigvitaliteit, de genetische aanleg voor moedereigenschappen en de maternaal genetische aanleg (het baarmoedereffect) geschat. Helaas is dit voor de huidige stand van de techniek teveel gevraagd. De schattingen van de genetische parameters lopen in een analyse met drie bovengenoemde genetische effecten naar onrealistisch hoge waarden of worden niet geschat. Een belangrijke verklaring hiervoor is dat biggen voor het overgrote deel gezoogd worden door hun biologische moeder. Het is daarom moeilijk om een goed onderscheid te maken tussen maternaal effect en moedereigenschappen. Bestudering van detailresultaten wijst uit dat alle drie genotypen van belang zijn, maar dat een combinatie van twee van de drie de waargenomen verschillen in overleving ook redelijk kan beschrijven. De keuze voor een model met een combinatie van bigvitaliteit en moedereigenschappen van de zeug is vooral ingegeven door de goede interpretatie van de resultaten.

\section{Werkt selectie op hogere overleving nu ook?}

Vervolgens is alle aandacht op bigvitaliteit gericht en gerekend met een model waarin als enig genetisch effect het dier is meegenomen. Fokwaarden werden geschat voor worpen van hoogdrachtige dieren en vervolgens is gekeken of de geboren biggen voldeden aan hun verwachting. Dit klopte heel mooi voor vitaliteit (één procent betere fokwaarde vitaliteit leverde inderdaad één procent meer echte overleving op) en het klopte voor geboortegewicht. In groepen met een hoge fokwaardeschatting voor vitaliteit waren de biggen inderdaad vitaler en in beide geboortegewicht situaties waren biggen met een hoge fokwaarde voor geboortegewicht wezenlijk zwaarder. Selectie op vitaliteit en/of geboortegewicht zal daarom succesvol zijn. 
Interessant is wat er daarnaast gebeurt, de gecorreleerde responsen. Selectie op een hoger geboortegewicht had geen wezenlijke stijging van de vitaliteit tot gevolg en selectie op vitaliteit liet het geboortegewicht vrijwel onaangeroerd. In alle vitaliteits analyses werd de uniformiteit van de worp groter, een resultaat dat ook al eerder gevonden was.

Het loont de moeite om eens goed naar Tabellen $2 \mathrm{a}$ en $2 \mathrm{c}$ van Hoofdstuk 4 te kijken. Hier is steeds een groep dieren in tweeën gedeeld op basis van fokwaarde. Bij voldoende groepsgrootte is bij een fifty-fifty verdeling ongeveer het resultaat van twee jaar selectie te zien. Iemand die wil weten wat er in de nabije toekomst van de fokkerij verwacht kan worden, verdeelt een groep zeugen of vleesvarkens in tweeën en kijkt onder zijn/haar eigen omstandigheden wat het verschil is in een aantal kenmerken. De helft van dit verschil mag aan jaarlijkse verandering verwacht worden bij een gelijkblijvend fokkerijbeleid.

So far, so good

Stand van zaken na deze analyses: biggen kunnen vitaler gemaakt worden, zonder dat worpgrootte hoeft te dalen en zonder dat het geboortegewicht hoeft te stijgen. Tegelijkertijd zal de uniformiteit van de worp stijgen. De verhoogde vitaliteit uit zich voor eenderde in minder dood geboren en voor tweederde in een lagere sterfte tot spenen.

Ondertussen is er dan nog geen expliciet gebruik gemaakt van selectie op maternale invloeden of selectie op moedereigenschappen. Er zijn daarom volop mogelijkheden om het aantal gespeende biggen per worp te verhogen zonder dat de worpgrootte bij geboorte stijgt.

\section{Mesterij eigenschappen vergeten?}

Doel van de varkenssector is te komen tot een efficiënte productie van mager vlees van een goede kwaliteit. Daarom is ook gekeken naar de relaties tussen bigvitaliteit, geboortegewicht en grootbrengend vermogen enerzijds en mesterijeigenschappen anderzijds. Conclusie uit deze analyses was dat deze relaties belangrijk zijn. Selectie op mesterijeigenschappen heeft als gecorreleerde respons gevolgen voor vitaliteit en grootbrengend vermogen. Omgekeerd: selectie op verbeterde overleving heeft gevolgen voor mesterijeigenschappen. Genetisch vitale biggen eten in de mesterijfase meer, groeien harder en vormen meer vet, met als gevolg dat ze meer rugspek hebben. Terwijl 
genetisch magere en genetisch langzaam groeiende dieren als big zwakker zijn. Uit nadere studie van de literatuur blijkt dit vaker gevonden te worden dan in eerste instantie verwacht. Dit wijst erop dat de energiereserves van dieren goed in de gaten gehouden moeten worden.

Geboortegewicht is een kenmerk van de zeug (zie eerder) en heeft een positief verband met levensgroei en een negatief met rugspek. Selectie op hard groeiende, magere zeugen betekent dat de biggen bij geboorte zwaarder worden. Nieuwe stand van zaken: selectie op vitaliteit houdt risico's in voor de karkaskwaliteit, maar geeft mogelijkheden in termen van voeropname en groei. Biggen die bij de geboorte zwaar zijn doen het goed in de vleesvarkenshouderij en selectie op mesterijeigenschappen in een zeugenlijn levert zeugen, die zwaardere biggen geven.

\section{Wat zijn de verwachtingen voor de genetische trend in vruchtbaarheidskenmerken?}

Gewapend met deze kennis moet het mogelijk zijn een idee te geven wat verschillende selectiestrategieën naar verwachting op kunnen leveren. Tabel 2 geeft in de eerste kolom een idee van de gemiddelde Nederlandse vruchtbaarheidsgegevens in 2001 (afgeleid van Kengetallenspiegel SIVA 1999), met een paar aanpassingen. Het percentage doodgeboren biggen is toegevoegd evenals de bigoverleving. Het gemiddelde geboortegewicht is aangenomen als $1,45 \mathrm{~kg}$ per big. De gemiddelde worpmassa is vervolgens berekend en als variatie in het geboortegewicht is 280 gram per worp aangehouden. Genetische parameters zoals eerder geschat zijn toegepast. De werkelijke respons hangt af van de exacte uitvoering van het fokprogramma. De verschillende strategieën zijn met dezelfde aannames berekend en geven daarmee een aardig idee van de verschillen die verwacht mogen worden. De cijfers kunnen gelezen worden alsof er staat 'per 6 jaar', 2010 moet in dat geval vervangen worden door 2007. Dit geeft dan de verwachting voor een zeer efficiënt opererend fokprogramma aan. Of ze kunnen gelezen worden als 'per 6 generaties' (een generatie is 1.5-2.0 jaar), dit betreft dan een 'normaal' fokprogramma. Zes keer 1.5 jaar is negen jaar. Uitgaande van een huidige situatie in 2001, zoals aangegeven in de kolombasis, zien de gemiddelde vruchtbaarheidsgegevens in Nederland er in 2010 uit zoals in Tabel 2 aangegeven.

$\mathrm{Bij}$ de selectiestrategie Worpgrootte wordt uitsluitend en alleen geselecteerd op meer biggen per worp. Dit leidt tot duidelijk meer geboren biggen per worp en tot een stijging van ongeveer 0.25 gespeende biggen per zeug per jaar. Bigoverleving daalt doordat het 
aantal doodgeboren biggen per worp licht stijgt en vooral doordat de sterfte tot spenen van 12.7 tot $15.2 \%$ stijgt.

Een strategie waarbij even hard geselecteerd wordt op zowel worpgrootte als geboortegewicht (Worpgrootte + Geboortegewicht) geeft als interessant resultaat een gelijk blijven van het aantal gespeende biggen per zeug per jaar en een aanzienlijke stijging van het geboortegewicht. Uitsluitend selecteren op Overleving is gezien de titel van dit proefschrift een uitdaging, en levert inderdaad duidelijk minder sterfte en toch meer biggen per zeug per jaar op.

Optimale selectie, dat wil zeggen de strategie die het economisch rendement maximaliseert, staat weergeven onder Economie. Deze strategie levert inderdaad de meeste gespeende biggen per zeug per jaar, met een lichte stijging van de bigoverleving en een duidelijke daling van het geboortegewicht.

Tabel 2: Verwachte selectie responsen voor vruchtbaarheidseigenschappen bij verschillende selectie strategieën na 6 generaties selectie.

\begin{tabular}{lc|ccccc}
\hline & 2001 & \multicolumn{5}{|c}{2010} \\
\hline & Basis & Worp- & Worpgr + & Over & Eco- & Duur- \\
& & grootte & Gebgew. & Leving & nomie & zaam \\
\hline Worp index & 2,32 & 2,35 & 2,35 & 2,35 & 2,35 & 2,35 \\
Totaal geboren & 12,20 & 13,70 & 12,26 & 11,78 & 13,46 & 12,80 \\
Levend geboren & 11,30 & 12,72 & 11,22 & 11,10 & 12,66 & 12,11 \\
Doodgeboren & 0,90 & 0,98 & 1,04 & 0,68 & 0,80 & 0,69 \\
\%Doodgeboren & 7,38 & 7,14 & 8,46 & 5,76 & 5,94 & 5,40 \\
\%Kraamstalsterfte & 12,90 & 15,72 & 12,78 & 8,16 & 13,86 & 10,98 \\
Big overleving & 80,3 & 78,3 & 79,8 & 86,6 & 81,0 & 84,2 \\
Gespeend/worp & 9,80 & 10,72 & 9,79 & 10,20 & 10,91 & 10,78 \\
Gespeend/z/j & 22,8 & 25,2 & 23,0 & 23,9 & 25,6 & 25,3 \\
Geboortegewicht & 1,45 & 1,34 & 1,74 & 1,47 & 1,35 & 1,39 \\
Variatie in geb.gew & 280 & 280 & 310 & 268 & 274 & 268 \\
Worp massa & 17,7 & 18,4 & 21,3 & 17,4 & 18,1 & 17,8 \\
\hline
\end{tabular}

In de laatste kolom, tenslotte, staat Duurzaam, in deze strategie is de waarde van overleving (subjectief) verdubbeld. Het resultaat in termen van gespeende biggen per 
zeug per jaar is vergelijkbaar aan het resultaat van selectie op uitsluitend worpgrootte. De onderliggende kenmerken voor deze strategie geven een rustiger trend voor worpgrootte en een aanzienlijke verbetering van de bigoverleving.

\section{En voor de mester?}

Voor mesterijeigenschappen zijn vergelijkbare analyses uitgevoerd (Tabel 3). De tijdshorizon is wat korter genomen, omdat via berenlijnen betrekkelijk snel vooruitgang geboekt kan worden. De generatie-interval blijft hier kort en de dieren kunnen getest worden voordat ze nakomelingen gaan produceren, dit in tegenstelling tot vruchtbaarheids kenmerken. Ook hier geldt weer dat in een efficiënt fokprogramma het generatie interval korter kan zijn dan de 1,5 jaar die hier weergegeven is.

Het eerste alternatief is een strategie gericht op het uitsluitend verbeteren van groei en vleespercentage (Eenvoudig), alleen deze twee kenmerken worden geregistreerd. Het leidt tot een verhoging van de voeropname, de groei en ook nog het vleespercentage. Bigoverleving neemt echter af.

Een strategie gericht op de gelijktijdige economische verbetering van groei, vlees, voederconversie en overleving (Alles, alles willen en alles meten) levert een verbeterde groei en voederconversie op en een spectaculaire verhoging van de big overleving van 80.3 naar 92.3 in 4 generaties. De $92.3 \%$ is geen type fout, het is keer op keer nagerekend, met de resultaten van dit proefschrift wordt dit echt voorspeld.

Tabel 3: Verwachte selectie responsen voor mesterij eigenschappen bij verschillende selectie strategieën na 4 generaties selectie.

\begin{tabular}{lc|cccc}
\hline & 2001 & \multicolumn{4}{|c}{2007} \\
\hline & Basis & $\begin{array}{c}\text { Een- } \\
\text { voudig }\end{array}$ & Alles & $\begin{array}{c}\text { Een-voudig } \\
\text { Plus }\end{array}$ & $\begin{array}{c}\text { Geboorte } \\
\text { gewicht }\end{array}$ \\
\hline Mesterij groei & 780 & 864 & 840 & 884 & 792 \\
HGP & 55,8 & 56,8 & 56,1 & 55,7 & 56,1 \\
Voeropname & 2,10 & 2,24 & 2,12 & 2,38 & 2,06 \\
Voeder conversie & 2,69 & 2,59 & 2,53 & 2,70 & 2,60 \\
Big overleving & 80,3 & 78,3 & $92,3^{1}$ & 84,3 & 80,5 \\
Geboortegewicht & 1,45 & 1,51 & 1,47 & 1,48 & 1,77 \\
\hline
\end{tabular}

'zie tekst 
Wat een rol kan spelen is dat de verbanden bepaald zijn in een berenlijn, waar de spekdikte een stuk lager ligt dan bij het gemiddelde vleesvarken. Het kan zijn dat in deze lijn de spekdikte te laag wordt voor een goede vitaliteit van de biggen en dat het nog een aantal jaren duurt voordat de biggen in de vermeerdering in dezelfde situatie komen.

In Eenvoudig plus worden alleen groei en spekdikte gemeten, maar wordt wel geprobeerd om vooruitgang te blijven boeken op voederconversie en bigoverleving. Dit levert dan veel extra groei en een duidelijk verbeterde big overleving op, maar geen verbetering in vleespercentage en voederconversie. Selectie op mesterijeigenschappen levert iets zwaardere biggen. Selectie uitsluitend op Geboortegewicht leidt nauwelijks tot betere mesterij eigenschappen.

\section{Conclusies}

Uiteindelijk blijkt dat selectie op een betere bigoverleving mogelijk is. Het is nodig om sterfte te registreren. Er kan niet volstaan worden met het meten van geboortegewicht. Met het uiteenrafelen van de genetische effecten van moeder, pleegmoeder en de big zelf lijkt voordeel te behalen. Echter dit is sterk afhankelijk van het percentage overgelegde biggen.

Veel kenmerken hangen samen met overleving van biggen. De resultaten uit dit proefschrift laten zien dat een verbetering van bigvitaliteit gecombineerd kan worden met een genetische verbetering in de overige kenmerken. 


\section{Summary}

Piglet mortality is high. In the USA nearly $20 \%$ of the piglets do not survive between late gestation and weaning; $7 \%$ of the piglets die during farrowing and some $13 \%$ are lost during lactation. These statistics from the USA are no exception to the norm. In the Netherlands mortality is similar, although the average litter size is somewhat higher. Often the sow is blamed: the sow's disposition or insufficient milk production causes piglets that have been laid on or are unthrifty.

Table 1: Three sows with individual piglet data.

\begin{tabular}{|c|c|c|c|c|c|c|}
\hline Sow number & 5647837 & 5738121 & & & 6134678 & \\
\hline Line & 020 & 020 & & & 020 & \\
\hline Parity & 7 & 7 & & & 1 & \\
\hline Year & 1999 & 1999 & & & 1999 & \\
\hline Total number born & 16 & 16 & & & 17 & \\
\hline Litter weight (kg) & 19,6 & 21,0 & & & 20,5 & \\
\hline Average birth weight (kg) & 1,23 & 1,31 & & & 1,21 & \\
\hline Variation in birth weight $(\mathrm{g})$ & 378 & 354 & & & 178 & \\
\hline Gestation length & 115 & 111 & & & 114 & \\
\hline Piglet mortality & $6 \%$ & $56 \%$ & & & $5 \%$ & \\
\hline \multicolumn{7}{|l|}{ Piglets } \\
\hline 1 & 0,60 & 0,70 & $\dagger$ & $\leftarrow$ & 0,71 & \\
\hline 2 & 0,60 & 0,80 & $\dagger$ & & 1,03 & \\
\hline 3 & 0,66 & 0,90 & $\dagger$ & & 1,04 & \\
\hline 4 & 0,96 & 1,12 & $\dagger$ & & 1,07 & \\
\hline 5 & 1,04 & 1,14 & $\dagger$ & & 1,11 & $\dagger$ \\
\hline 6 & 1,16 & 1,18 & & & 1,15 & \\
\hline 7 & 1,22 & 1,20 & & & 1,16 & \\
\hline 8 & 1,26 & 1,22 & $\dagger$ & & 1,17 & \\
\hline 9 & 1,28 & 1,26 & $\dagger$ & & 1,26 & \\
\hline 10 & 1,30 & 1,28 & $\dagger$ & & 1,27 & \\
\hline 11 & 1,32 & 1,62 & $t$ & & 1,31 & \\
\hline 12 & 1,44 & 1,64 & & & 1,32 & \\
\hline 13 & 1,58 & 1,68 & & & 1,33 & \\
\hline 14 & 1,58 & 1,72 & & & 1,35 & \\
\hline 15 & 1,76 & 1,74 & & $\leftarrow$ & 1,35 & \\
\hline 16 & 1,80 & 1,84 & & $\leftarrow$ & 1,40 & \\
\hline 17 & & & & $\leftarrow$ & 1,42 & \\
\hline
\end{tabular}

$\uparrow$ Piglet died during farrowing or lactation

$\leftarrow$ Piglet cross-fostered to another sow 
In this thesis we tried to figure out if there are genetic contributions to the survival of piglets from the uterus of the sow, from the piglet itself and/or from the nurse sow. Records have been kept since 1993 on a number of farms; birth weight, cross-fostering and mortality are recorded together with pedigree information and a number of litter traits. In Table 1 an example is given for three sows. Piglet survival for the first sow was $94 \%$, for the second $46 \%$ and for the third $95 \%$.

From the first sow the 4 smallest piglets were cross-fostered, from the third sow the tree heaviest and one smallest. All 8 cross-fostered piglets survived at their nurse mother. The third sow is actually a first parity sow, with an amazing $20.5 \mathrm{~kg}$ litter weight, some $50 \%$ higher than average for a first parity sow. Still, the average birth weight of the piglets was only $1.21 \mathrm{~kg}$. Uniformity was very high, the smallest piglet was $710 \mathrm{~g}$ and the heaviest $1420 \mathrm{~g}$, and the average variation in birth weight only $178 \mathrm{~g}$, while the norm is $280 \mathrm{~g}$. The only piglet that died had an almost average birth weight. This is the type of sow we would like: a large litter at a low parity, high litter weight, very good uniformity, an adequate gestation length and excellent survival of piglets. Data on some 33.000 litters and some 400.000 piglets were available for analysis.

\section{Litters and sows}

The first traits to be analyzed were the sow traits, above the line in Table 1. Numerous people with even more numerous data sets analyzed litter size. Average heritability is 0.10 with little upward and downward variation. This means that $10 \%$ of the differences between sows for litter size has a genetic background. The heritability estimate from this data of 0.09 fits nicely with literature estimates. For the trait litter size we know that good genetic progress is possible at a rate of 0.15-0.25 piglets per litter per year, given a proper information and selection infrastructure.

It is therefore reassuring that the heritability of piglet survival is 0.06 , not too far from 0.09 . Heritability of uniformity in birth weight is 0.07 . The genetic correlation of uniformity with survival is clearly positive $(0.3)$, meaning that selection for more uniformity will increase survival and vice versa. A common sense expectation of the results would agree that more uniformity and easier survival do go hand in hand. What are not in agreement with common sense are the results of birth weight. Heritability of average birth weight of a litter is relatively good $(0.3)$, with remarkably little influence 
from the sire of the litter (0.02), contrary to cattle where the father of a calf is important for its birth weight. In pigs, birth weight of the piglets is determined for the major part by the sow and not by the piglet and/or the sire of the litter.

In Figure 1 the relationship between birth weight and piglet survival is given for two groups of piglets, one group with a high genetic expectation for survival and one group with a low expectation. The form of the curve is similar for both groups, but the group with the high expectation is shifted to lower birth weights. At the same weight small piglets of the high group survive much better than small piglets of the low group.

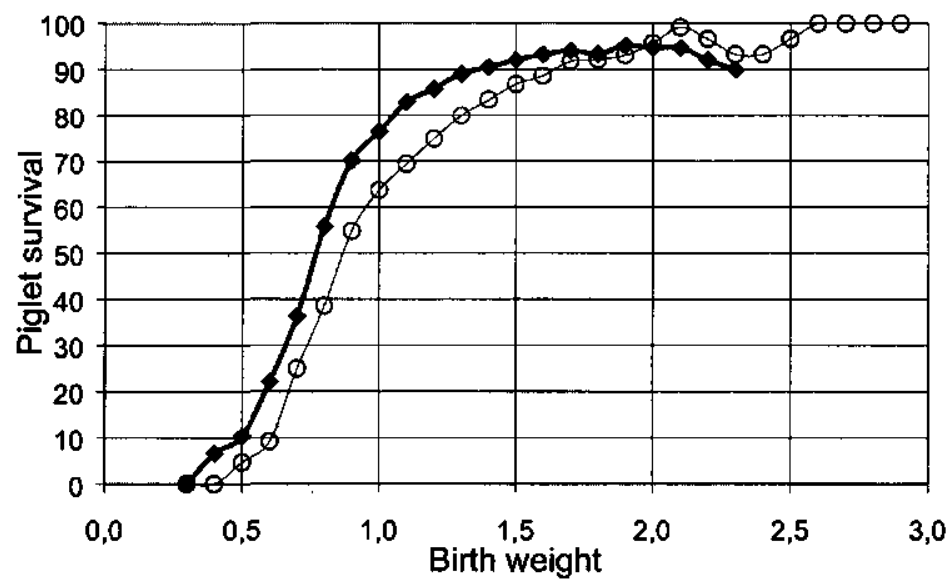

Figure 1: Relationship between birth weight and survival in a group of piglets with a

high genetic expectation for vitality ( - )and a group with a low expectation (0-0).

\section{Individual piglets}

After the litter analysis the same data were reanalyzed, but with the piglet in mind instead of the sow. Individual survival from late gestation to weaning is a somewhat tricky trait. Only two values are possible: the piglet dies (0) or it survives (1). A little survival or a little passing away is not an option. Chance plays an important role. In statistical terms this is error. Analysis of piglet survival yields a low heritability, but a relatively large amount of genetic variation, making selection difficult, but certainly not impossible. The challenge was to distribute this genetic variance to the different genotypes. What is mainly responsible for a good survival? Is it the uterine quality of the sow, the genotype of the piglet itself, or the mothering ability of the nurse sow? 
Cross-fostering of piglets is not a random process. Cross-fostered piglets are, on average, smaller than non-cross-fostered piglets. Cross-fostering is supposed to increase the average survival probability of piglets. Light piglets are moved to sows with an expected high mothering ability, proven in previous lactations or with an excellent udder. These sows, however, have an increased possibility of loosing piglets, since they get the small and weak piglets.

In the survival analyses a simultaneous estimation of the effects of birth weight, biological mother, piglet's genotype and nurse sow effect was performed. Unfortunately, this is too demanding for the current state of the technique. The discrimination between the effects of the biological mother and the nurse sow was especially difficult since only a limited number of piglets are cross-fostered (say $12 \%$ ). Less demanding analyses show influences of all three genotypes (sow, nurse sow and piglet), very roughly in equal parts. A good and interpretable model is a model with the genotype of the piglet and the genotype of the nurse sow.

\section{Does it work?}

Low heritability and reasonable genetic variation. Breeding values were estimated for litters of gestating sows, then realized survival was recorded and compared with the estimates. Results were very good; the top fifty percent of the litters had an expectation of 4-5\% higher survival, compared with the bottom fifty percent. Realized survival in the low group was $79 \%$ in a dam line and $81 \%$ in a sire line, while survival in the high group was $84 \%$ and $84 \%$, respectively. In the sire line, average birth weight in the high group was $70 \mathrm{~g}$ lower than in the low group, explaining why the realized difference in the sire line was not the predicted $4-5 \%$.

It is worthwhile to have a good look at Tables $2 a$ and $2 c$ of Chapter 4 . A fifty-fifty grouping was done on the basis of pedigree index for piglet survival and birth weight, respectively. If group size is large enough a fifty-fifty grouping gives a rough indication of two years' selection. If you would like to know what to expect of genetic progress, take a group of animals, split in into two on the basis of the selection index and look at your own production records for the difference in the performance of the animals. Half of this difference is what can be expected for change in one year if selection strategy remains constant. 
So far, so good

- Current status: selection for increased piglet survival is genetically possible without loss in litter size and without an increase in birth weight. Uniformity of the litter in terms of birth weight will increase. Increased survival is expressed in a decrease in percentage stillborn and a decrease in percentage pre-weaning mortality in a ratio of 1:2. Not all possibilities have been explored in this analysis; no explicit use of the knowledge on maternal and nurse sow effects has been made. There is even (somewhat) more potential than is shown here.

\section{What about finishing traits?}

The goal of pig production is to produce good quality lean meat as efficiently as possible. Therefore the relationships between piglet survival, birth weight and mothering ability on the one side and finishing traits on the other have been investigated. The conclusion was that the relationships are quite important. Vital piglets eat more, grow faster and produce more fat in their finishing phase. This means, looking at it the other way around, that genetically lean animals will be weaker in their perinatal phase. In literature there are more indications of this phenomenon than originally expected. Body reserves of piglets seem to play an important role.

Birth weight of the piglet is a trait of the sow (as discussed before) and has a positive genetic correlation with life daily gain and a negative correlation with backfat. Selection for fast growing lean animals will result in heavier piglets, if litter size remains constant.

New status: selection for increased piglet survival bears risks in terms of carcass quality, but offers opportunities in terms of feed intake and gain. Heavier piglets perform better during finishing and selection for lean gain will increase birth weight.

\section{What to expect of the genetic changes in fertility traits?}

Armed with this knowledge it should be possible to indicate what the result will be of different selection strategies. Table 2 shows an estimate of better performing farms in North America in 2001, with a few assumptions and some less than commonly used traits. Percentage stillborn is added, as is piglet survival, average birth weight is assumed to be $1.45 \mathrm{~kg}$ and 'within litter variation in birth weight' is $280 \mathrm{~g}$. Litter weight is the multiplication of litter size and birth weight. Genetic parameters, as estimated in the previous analyses, have been applied to a pig-breeding program. Different strategies have 
been analyzed with the same assumptions and differences between the strategies give a clear indication of what is to be expected from a change of strategy. Values can be read as 'result after 6 years of selection', in this case 2010 in Table 2 should be changed to 2007. This would be the result of a very efficient selection program. Or the values can be read as 'result after 9-10 years', in the case of a normal selection program, in Table 2 nine years was used.

Table 2: Expected production levels for fertility traits after 6 generations of selection using different strategies.

\begin{tabular}{lcccccc}
\hline & 2001 & & & 2010 & & \\
& & Litter & LS + & Survival & Eco- & Sustai- \\
size & BW & & nomy & nable \\
\hline Litter index & 2.32 & 2.35 & 2.35 & 2.35 & 2.35 & 2.35 \\
Litter size Total born & 12.20 & 13.70 & 12.26 & 11.78 & 13.46 & 12.80 \\
Live born & 11.30 & 12.72 & 11.22 & 11.10 & 12.66 & 12.11 \\
Stillborn & 0.90 & 0.98 & 1.04 & 0.68 & 0.80 & 0.69 \\
\%Stillborn & 7.38 & 7.14 & 8.46 & 5.76 & 5.94 & 5.40 \\
\%Pre-weaning mort. & 12.90 & 15.72 & 12.78 & 8.16 & 13.86 & 10.98 \\
Piglet survival & 80.3 & 78.3 & 79.8 & 86.6 & 81.0 & 84.2 \\
Weaned/litter & 9.80 & 10.72 & 9.79 & 10.20 & 10.91 & 10.78 \\
Weaned/sow/year & 22.8 & 25.2 & 23.0 & 23.9 & 25.6 & 25.3 \\
Ave. Birth weight (BW) & 1.45 & 1.34 & 1.74 & 1.47 & 1.35 & 1.39 \\
Variation in BW & 280 & 280 & 310 & 268 & 274 & 268 \\
Litter weight & 17.7 & 18.4 & 21.3 & 17.4 & 18.1 & 17.8 \\
\hline
\end{tabular}

Litter size indicates a strategy, in which selection is solely on litter size. This results in a clear increase in litter size $(+1.50)$, and a clear increase in weaned per litter $(+0.92)$. Piglet survival decreases especially because of an increase in pre-weaning mortality $(+2.8 \%)$. Average birth weight decreases by $110 \mathrm{~g}$ per piglet.

A natural reaction is to try to counterbalance the reduction in birth weight with selection. A strategy for Litter size +birth weight $(L S+B W)$ together, assuming equal selection pressure on both traits, yields an interesting result, litter size will remain constant as will piglets/sow/year and birth weight will increase substantially. Survival is 
similar to the current level. This result is in agreement with aforementioned results. Selection for increased birth weight will not increase survival.

Selection based solely on survival results in a slight decrease in litter size, a marked increase in survival and in more weaned piglets per litter.

Optimal selection, that is the strategy that maximizes profit, is given under economy. And indeed, this strategy yields the highest number of weaned piglets per sow per year. Increase in litter size is lower than in litter size, but survival is higher and the net result is positive. Still, piglet survival is almost at the same level as in the current situation. Quite subjectively the economic weighing of survival has been doubled and the results are given in the column sustainable. This strategy gives a similar result as littersize in terms of weaned piglets per sow per year, but the underlying values show a more relaxed picture. Litter size total born increases with 'only' 0.6 piglets per litter and survival increases with $4 \%$, number of stillborn drop to 0.7 piglets per litter and pre-weaning mortality from 13 to $11 \%$, litter weight is similar to the 2001 situation, piglets are $60 \mathrm{~g}$ lighter, but more uniform.

\section{And the finisher?}

For finishing traits similar analyses were performed. Time horizon was shortened (4 generations), because in sire lines genetic progress is relatively fast. Generation interval is short and animals can be tested before they become reproductive, this is contrary to fertility traits. Similarly, as mentioned before, here too the generation interval in an efficient selection program can be shorter than the 1.5 years.

The first alternative is a simple strategy aimed at improving gain and meat percentage and observations are on gain and backfat only. Gain increases, meat percentage increases and as correlated responses feed intake increases and piglet survival decreases by some 2 percent in 4 years.

A strategy aimed at improving all important traits and measuring all important traits will give an improved gain, an improved feed conversion and a spectacularly improved piglet survival, from $80 \%$ to $92 \%$. This analysis has been redone several times, always with the same result. A possible explanation is that the genetic parameters were estimated in a sire line. Selection animals are much leaner than the normal slaughter pig and it is possible that the leanest animals are approaching their bottom line in terms of body reserves. Heritability of piglet survival in the sire line is higher than in the sow line, 
possibly because of this phenomenon. If true it explains the strong correlation between backfat and survival and the large responses of piglet survival to changes in strategy.

Table 3: Expected production levels for finishing traits after 4 generations selection using different strategies.

\begin{tabular}{lc|cccc}
\hline & 2001 & \multicolumn{4}{|c}{2007} \\
\hline & & Simple & All & $\begin{array}{c}\text { Simple } \\
\text { plus }\end{array}$ & $\begin{array}{c}\text { Birth } \\
\text { weight }\end{array}$ \\
\hline Finishing gain & 780 & 864 & 840 & 884 & 792 \\
Lean percentage & 55.8 & 56.8 & 56.1 & 55.7 & 56.1 \\
Feed intake & 2.10 & 2.24 & 2.12 & 2.38 & 2.06 \\
Feed conversion & 2.69 & 2.59 & 2.53 & 2.70 & 2.60 \\
Piglet survival & 80.3 & 78.3 & 92.3 & 84.3 & 80.5 \\
Birth weight & 1.45 & 1.51 & 1.47 & 1.48 & 1.77 \\
\hline
\end{tabular}

In the simple plus strategy observations are only taken on gain and backfat, but the breeding goal covers all important traits and all parameters are known. In comparison with the simple strategy selection response shifts to gain and feed intake, survival is increased, but lean percentage and feed conversion remain constant. Selection on different indexes of finishing traits increases birth weight somewhat. Selection solely on birth weight does not improve finishing traits.

\section{Conclusions}

Finally it is concluded that genetic variation for piglet survival exists and that selection for survival is possible. For a successful selection program it is necessary to record survival, sole recording of birth weight is not sufficient.

It appears that advantage can be gained from a good attribution of the genetic variation to the sow, the nurse sow and the piglet. A proper attribution is only possible when crossfostering percentage is high. However, if only the genotype of the piglet is considered, marked differences in piglet survival can already be seen between contemporary animals with a high and low genetic expectation for piglet survival. 
Many traits have genetic relationships with piglet survival; especially traits in the growing phase have important genetic relationships with piglet vitality. The results from this thesis show that it is possible to combine selection for increased piglet survival with genetic improvement in other economically important traits.

Piglet losses were classified as:

(j) weaned - piglets that reached 35 days of age.

McKay (1993) 


\section{Curriculum vitae}

Egbert Frank Knol werd geboren op 21 Augustus 1957 in Putten, Gelderland. Woonachtig op Gymnasiumstraat 40 te Leeuwarden bezocht hij het Christelijk Gymnasium op de Gymnasiumstraat 36 te Leeuwarden. Met het diploma van dit instituut op zak begon hij in 1975 aan een studie Zoötechniek, die in augustus 1982 met succes afgerond werd. Na twee seizoenen lesgeven aan de Mas-sen in Doetinchem en Barneveld werd hij door de Unilever Vleesgroep aangenomen als geneticist bij Varkens Onderzoeks Centrum Nieuw Dalland bv in Merselo, Limburg. In 1988 trad hij in het huwelijk met Annelies Schoenmakers. Uit dit huwelijk werd in 1989. Reijer Nico geboren en in 1991 Jolan Martin. Inmiddels is hij, na een aantal fusies in de varkensfokkerijwereld, werkzaam als geneticus bij het IPG, het Institute for Pig Genetics B.V. in Beuningen, Gelderland. Interesse velden waren in de loop van de jaren onder meer: bouw en implementatie van BLUP fokwaardeschattingsprogrammas met name gericht op vruchtbaarheid, internationalisatie van de fokkerij, eiwit en vetaanzet van groeiende varkens, implementatie van het gebruik van kruisingsinformatie en de genetische aspecten van de productie van Parma hammen. 